Journal of Agricultural Science in Finland

Maataloustieteellinen Aikakauskirja

Vol 63:143-254

\title{
DETERMINATION OF THE CAPITALIZED AND MARKET VALUES OF SUPPLEMENTARY ARABLE LAND IN SOUTHERN FINLAND, 1972-1986
}

Selostus: Lisäpellon tuotto- ja kauppa-arvon määrittämisen perusteet ja soveltuvuus pellon arvon osoittamiseen Etelä-Suomessa vuosina $1972-1986$

\section{MATTI YLÄTALO}

Pellervo Economic Research Institute

Revontulentie $8 \mathrm{~A}$

SF-02100 Espoo, Finland

ACADEMIC DisSERTATION

TO BE PRESENTED, WITH THE PERMISSION OF THE

FACUlty of Agriculture AND Forestry of THE

UNIVERSITY OF HELSINKI, FOR PUBLIC CRITICISM

IN AUditorium Porthania III

ON OCTOBER 25th, 1991, AT 12 O'CLOCK.

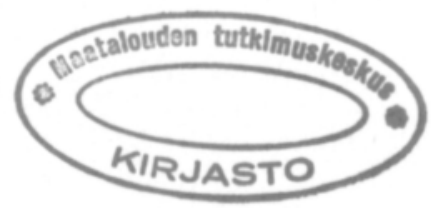





\section{PREFACE}

With the completion of this thesis, I wish to acknowledge all those individuals from whom I have received encouragement and support throughout the various phases of my work.

The study was begun in the Department of Agricultural Economics at the University of Helsinki, where I held the post of Junior Researcher, financed by the Academy of Finland. In 1984, I moved to Pellervo Economic Research Institute (PTT), where the theoretical part of my study was completed. I was able to concentrate on the empirical part of the study while serving as an Assistant in the Department of Agricultural Policy at the University of Helsinki, in 1989.

First, I wish to extend my warmest thanks to Professor, the Department Head Viljo Ryynänen, in the Department of Agricultural Economics, for his guidance throughout the study. My interest in the appraisal of real estate, especially concerning agricultural land, is largely due to his influence. The Managing Director of PTT, Professor Pertti Kukkonen, as my main academic advisor, has provided valuable comments which have assisted me in improving the empirical analyses, as well as sharpening the English terminology. To him, and to my second academic advisor, Professor Matias Torvela, Director of the Agricultural Economics Research Institute, I extend my gratitude for their cooperation.

I also extend my thanks to the Vice Rector of the University of Helsinki, Professor Risto Ihamuotila for his continuing interest in my work. Similarly, Professor Kauko Hahtola has offered critical advice concerning the theoretical aspects of my work. Assistant Professor Ossi Heiskanen and the Department Head in the Association of Agricultural Advisory Centers, Mr. Mikko Siitonen, have also helped me with their constructive discussions.

Mr. Arto Latukka and Mr. Timo Räsänen have helped me in the collection and preparation of the empirical data from bookkeeping farms. They, together with the Agricultural Profitability Office Directors, Mr. Heikki Järvelä and Mr. Juhani Ikonen, earn my deepest gratitude. I also thank my colleagues at PTT, especially Research Directors, Mr. Erik Haggrén and Mr. Seppo Aaltonen, Secretary, Mrs. Ritva Tuutti, and Mr. Perttu Pyykkönen for their help and support at various stages of this work.

The original Finnish text was translated by Miss Ulla Palomäki and checked by Dr. Ashley Selby and Ms. Terese Forster, to whom I extend my thanks.

My research received financial support from the Kyösti Haataja Foundation and the Finnish Cultural Foundation (Veikko Ihamuotila scholarship). Further financial support was received from the Academy of Finland and PTT. I am most grateful for the support of these organizations. I also thank the Scientific Agricultural Society of Finland for permission to publish this study in its journal.

Finally, I thank my wife Marja for her support, understanding, and tolerance with respect to my thesis.

Helsinki, August 1991

Matti Ylätalo 



\section{Determination of the capitalized and market values of supplementary arable land in southern Finland, 1972-1986}

\section{Contents}

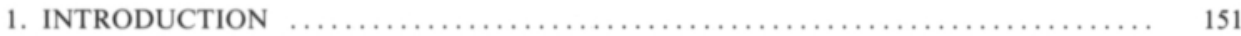

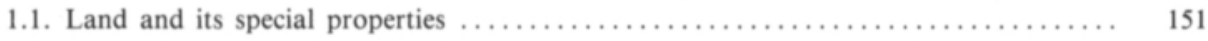

1.2. Essential concepts of value and price in the appraisal of agricultural land ....... 152

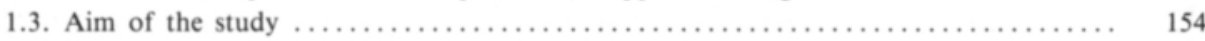

2. FACTORS INFLUENCING THE VALUE AND PRICE OF SUPPLEMENTARY ARABLE

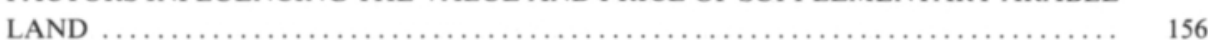

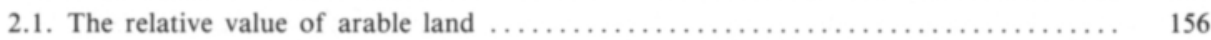

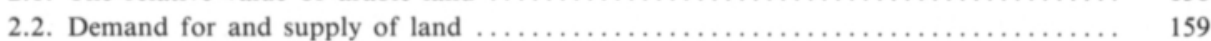

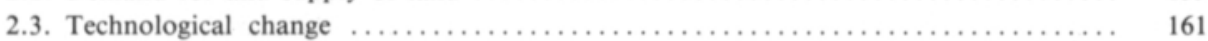

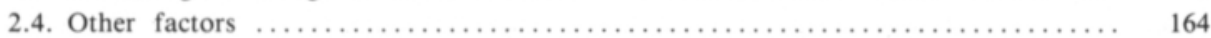

3. PREVIOUS STUDIES BASED ON THE CAPITALIZED AND MARKET VALUE AP-

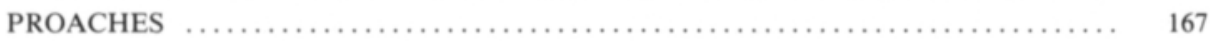

3.1. Studies based on the capitalized value approach $\ldots \ldots \ldots \ldots \ldots \ldots \ldots \ldots \ldots \ldots \ldots$

3.1.1. Basic principles for the determination of capitalized value $\ldots \ldots \ldots \ldots \ldots \ldots \quad 167$

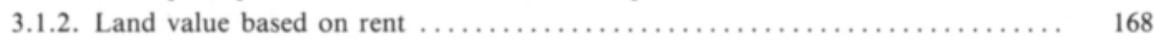

3.1.3. Determination of the value of supplementary arable land by the residual approach $\quad 170$

3.1.4. The value of supplementary arable land based on its marginal productivity ... 172

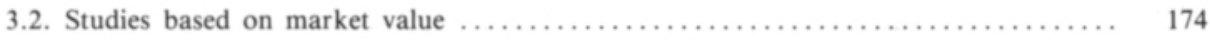

3.2.1. A general survey of price investigations concerning agricultural land ...... 174

3.2.2. Price investigations concerning supplementary arable land $\ldots \ldots \ldots \ldots \ldots \ldots \quad 177$

4. DETERMINATION OF THE CAPITALIZED VALUE OF SUPPLEMENTARY ARABLE

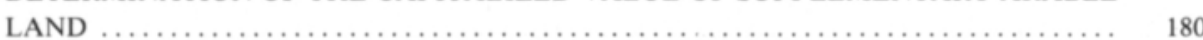

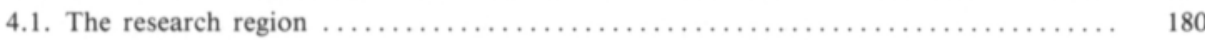

4.2. Agricultural conditions during the research period $\ldots \ldots \ldots \ldots \ldots \ldots \ldots \ldots \ldots \ldots \ldots, 181$

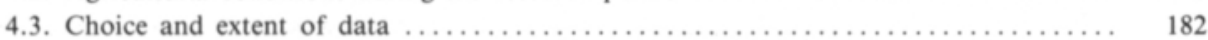

4.3.1. Private economic reasons for acquiring supplementary arable land $\ldots \ldots \ldots \ldots \quad 184$

4.3.2. Measuring the return from supplementary arable land $\ldots \ldots \ldots \ldots \ldots \ldots \ldots . \quad 187$

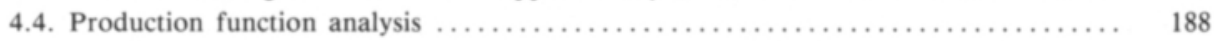

4.4.1. General grounds for the use of production functions $\ldots \ldots \ldots \ldots \ldots \ldots \ldots \ldots$

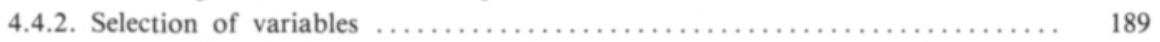

4.4.3. The functional form of the production function $\ldots \ldots \ldots \ldots \ldots \ldots \ldots \ldots \ldots, 191$

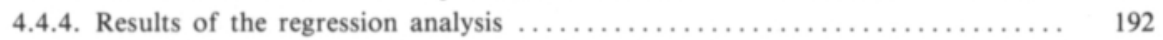

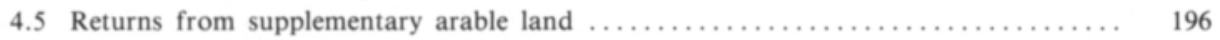

4.5.1. Returns from supplementary arable land by farm types $\ldots \ldots \ldots \ldots \ldots \ldots \ldots . \quad 196$

4.5.2. Return from supplementary arable land as a function of the size of farm ... 199

4.6. Assessment of the capitalized value of supplementary arable land . . . . . . . . 202

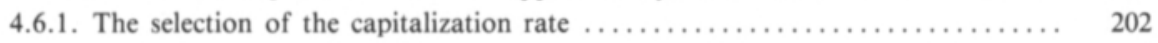

4.6.2. Capitalized value of supplementary arable land $\ldots \ldots \ldots \ldots \ldots \ldots \ldots \ldots .204$ 


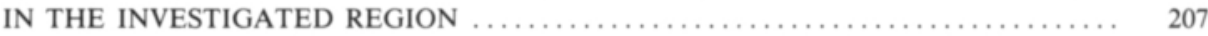

5.1. The collection and extent of data ................................. 207

5.2. Price level of supplementary arable land and its development ................ 210

5.2.1. Questions concerning the use and assessment of data on market prices ...... 210

5.2.2. Price of supplementary arable land and its development according to the market

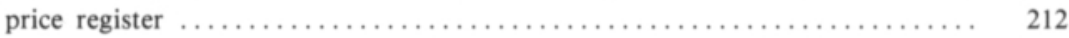

5.2.3. The price of supplementary arable land and its development according to purchases of arable land by the National Board of Agriculture ..................

5.2.4. Price differences between transactions of supplementary arable land in the market price register and the purchases of arable land by the National Board of Agriculture

6. COMPARISON BETWEEN CAPITALIZED VALUE AND MARKET PRICES OF SIJP-

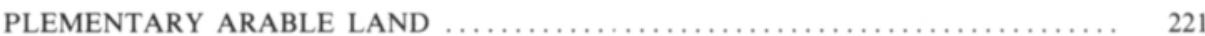

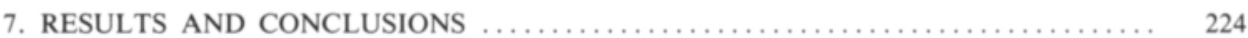

7.1. Return from supplementary arable land ........................... 224

7.2. Market prices of supplementary arable land ......................... 226

7.3. Correspondence between the capitalized and market values ................. 227

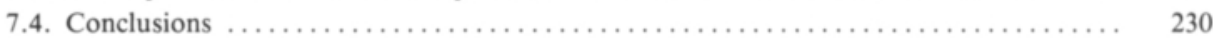

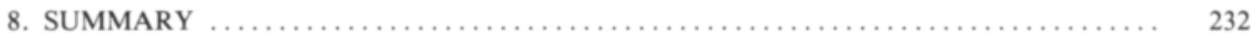

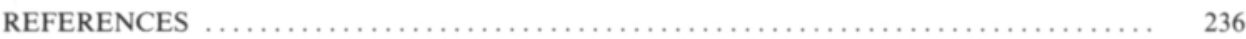

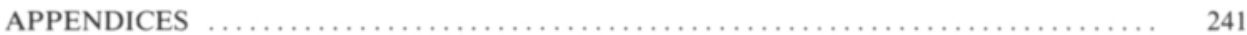

SELOSTUS: Lisäpellon tuotto- ja kauppa-arvon määrittämisen perusteet ja soveltuvuus pellon arvon osoittamiseen Etelä-Suomessa vuosina $1972-1986 \ldots \ldots \ldots \ldots \ldots \ldots . \ldots 252$ 


\title{
Determination of the Capitalized and Market Values of Supplementary Arable Land in Southern Finland, 1972-1986
}

\author{
MATTI YLÄTALO \\ Pellervo Economic Research Institute \\ Revontulentie 8 A, 02100 Espoo, Finland
}

\begin{abstract}
Rapid technological change in agriculture has permitted the management of larger farms with an existing labour input. Following this the demand for supplementary arable land has grown considerbly, while the supply has remained low. This imbalance between demand and supply has been reflected in rising land prices. For that reason, the main aim of this study was to determine the capitalized and market value of supplementary arable land and the correlations between them.

The determination of the capitalized value of supplementary arable land is based on the use of production function analysis. The marginal value product was estimated from a Cobb-Douglas function, using as independent variables, the production inputs, and a dummy variable for the quality of land. The present value of arable land was calculated by capitalizing the net marginal operating margin at interest rates of $3 \%, 5 \%$, and $7 \%$ for durations of return of 5,10 , and 15 years.

The benefit obtained from supplementary arable land proved highest on cattle farms with a small arable area, while on grain farms the marginal value product and the differential return still remained high as the size of the farm increased.

The real price of arable land in the annual purchases of land by the National Board of Agriculture rose very slightly, on an average of $1.7 \%$ per year, during the period $1972-1986$.

The capitalized value on the cattle farms reached the prices paid for arable land by the National Board of Agriculture, when a duration of return of 15 years and a capitalization rate of $3 \%$ was used. In contrast, the capitalized value of the grain farms did not reach, at any time during the study period, the price level of the National Board of Agriculture. Also, the market prices of arable land, according to the data collected by the National Board of Land Surveying, clearly exceeded the capitalized value of both cattle and grain farms, during the period 1982-1986.
\end{abstract}

Index words: Supplementary arable land, marginal value product, capitalization rate, capitalized value, market value 



\section{INTRODUCTION}

\subsection{Land and its special properties}

Land is a natural factor of production that is the basis of human life and activity. Land is destined for production, housing and recreation, while the raw materials used by the mining industry and for crop cultivation are derived from it. These raw materials provide the base for the production of more sophisticated goods.

For agricultural practices, land is the most important and qualitatively the most stable factor of production. Land is a necessary basic element, along with water, air, light and heat, for the satisfaction of different human needs. Land is also an object of possession and has certain special characteristics that most other goods lack. These characteristics are:

1. Land area is limited and it cannot be increased.

2. Land cannot be relocated.

3. Land cannot be entirely destroyed.

4. The productive capacity of land is limited.

Land's special attributes contain important implications. Since the land area is limited and cannot be relocated, a lack of land is created, especially around large population centers. On the other hand, the area of agricultural land is elastic, to a certain extent, because it can be increased by land clearing or by draining wetlands.

In some cases it is possible to move land blocks from one place to another. Yet, this is expensive and often impossible. The ground always remains where it is. In the same way, land can be reclaimed from lake or sea beds, but this method of land acquisition is of marginal significance, at least in Finland. According to Aereboe (1923, p. 21), land destruction extends, in the first place, to sand, clay, humus, lime, and large and small stones composing the superstratum.

Natural conditions and cultivation methods can change the proportions of the abovementioned substances, and yet the ground is permanent and cannot be destroyed. For this reason, GolTz (1905, p. 18) separates from land all factors of production that change either immediately or when being used. These are food-stuffs, firewood and stocks. The exploitation of buildings also ends after a certain time. By the limited productivity of the soil, Goltz (1905, p. 19-20) means the reduction of the productivity of the soil if it is perpetually used for crop production without adequate fertilization.

According to SiEBERT (1969, p. 40), there are no production costs related to land because of the indestructibility of the soil. WENTRUP (1978, p. 8) considers this view quite precarious, and argues that it is uncultivated land that implies no cost. Putting land to economic use, that is to say converting it to arable from the uncultivated state, almost always produces costs. These costs are so closely related to land that they must be considered as "'belonging to the land". The economic measures applied to land are scarcely arithmetically discernable and, thus, difficult to separate from the price of the land.

Although land's special characteristics are not absolute, they tend to make its supply inelastic. As land cannot be increased by production, the determination of its price is not the same as with other mass production goods. 
Consequently, according to CASSEL (1938, p. 276), land price is a secondary product of its own yield. The productivity of land cannot be infinitely increased by intensive methods, and yet, because of population growth, more and more submarginal land must be cultivated. As a result, the decrease of available land can lead to overpopulation. This is why some researchers in agricultural economics consider that agricultural land possesses monopolistic characteristics, if only partially, compared to other capital (e.g. RENNE 1947, p. 9). On the other hand the more recent literature (e.g. FeUERSTEIN 1970, p. 4) rejects the concept that the inelasticity of supply results in a situation in which only demand determines land price (compare NositschKA 1973, p. 11).

The concept of land is very extensive. A narrow definition includes only the solid part of the land surface. BARLOWE's $(1958$, p. 7) economic definition sums the capital jointly created by nature and man upon the land surface. This economic concept is comparable to Gryst's and TIMmONS's (1961) definition in which land resources are defined by the following characteristics: 1) natural characteristics, e.g. soil and climate; 2) characteristics created by society, e.g. location and civil engineering: road networks, drainage and flood protection; and 3 ) investments closely related to the soil, such as terracing embankments and measures to improve fertility. Timmons (ref. REYNOLDS 1966, p. 5) includes in the concept of land resources both the underground resources and surface resources. From the juridical point of view, land signifies any surface part of the land which can be an object of proprietary rights (BARLOWE 1958, p. 7).

There are different ownership concepts concerning this kind of good. One of the most familiar is the socialistic view claiming that land, as a factor of production, must belong to the state. Opposed to this is the capitalistic view which allows and protects private property. Between the extremes there are types of joint ownership, in which a family, village, or small community may possess land areas for common use. On the other hand, the content of the property concept has changed over time, along with social development (HyvöNEN 1982, p. 58-69).

In most cases, bringing arable land into cultivation involves considerable costs. In agricultural economics, there has been considerable debate on whether the cost of land clearing accrue to the actual value of agricultural land or whether it belongs to land improvements (e.g. LaUR and Howald 1957, p. 21-22). IhamUotila (1983, p. 10) claims that clearing costs should be included in the land value, because the value added clearing creates is stable, and thus comparable to the soil value.

Due to its special attributes, land differs from other means of production in agriculture, since land is able to produce crops and services continuously. If managed properly, its value is retained and no depreciations are made from the land (LAUR 1928, p. 85).

There are no maintenance costs related to land. On the other hand, agricultural land is closely related to land improvements, to buildings and to expected harvest. The separation of agricultural land and property has not always been apparent and incontestable (e.g. Thaer 1880 , p. 19, Aereboe 1919, p. 51-52, LAUR 1928, p. 17). With the development of agricultural economics terminology, confusion between land and other means of production is disappearing. At present, land improvements include only such land-related works that have to be renovated from time to time and, therefore, their value must be depreciated (compare МӒKı 1964, p. 114).

\subsection{Essential concepts of value and price in the appraisal of agricultural land}

In the economic literature, the concept of value is often divided into objective and subjective values. The classical school determined the objective value of goods by reference to the production cost. According to this theory, the value of a commodity, for example land, is defined by the highest production costs. That is to say, by those production costs creat- 
ed under the most unfavourable conditions (e.g. Ricardo ref. Gonner 1937, p. 37, ThüNEN 1921, p. 106, Marshall 1920, Clark 1923 and CASSEL 1938). The objective value is often identified by the price of the commodity, even if there is no direct exchange of commodities. Accordingly, VIROLAINEN (1950, p. 21), in his extensive investigation of the economic concepts of the value and price of agricultural land, formulates the objective value as a price relation that indicates the relation between the price of a commodity and the prices of other commodities. Similarly, VARTIAINEN (1963, p. 135) argues that the value of a commodity can be signified by another commodity as a unit of measure. Thus, value is defined as "the quantity of the second commodity in exchange to one unit of the first commodity". As a result, the objective value is the economic value measured in a generally accepted way. The Association of Finnish Real Estate Valuers (ANON. 1986, p. 15) defines objective value as "the value defined at the moment of appraisal, based on the generally accepted characteristics of the object'. Many publications of agricultural economics have dealt with objective values and their applicability to real estate economics (e.g. MÄKI 1945, p. 45, RYYNÄNEN 1967, p. 40).

The theory of subjective value, on the other hand, aims to determine the significance of commodities for the satisfaction of human needs (compare ViRTANEN 1966, p. 18). Such values can be based on sentimental motives (Măkı 1964, p. 102). BARLOWE (1958, p. 83) states that political, mental, social, and spiritual values are strongly subjective. Subjective values are therefore not measurable in a generally accepted way. Consequently, their study is difficult and the results often arbitrary.

According to Kantola (1977, p. 7-8), there are also static and dynamic values. The former is defined as the capacity of a commodity to satisfy human needs, as well as being concerned with the realization of benefits, while the latter is concerned with time scale. When conditions at the moment of appraisal are of greatest importance, priority is given to the static value. On the other hand, when the succeeding conditions already have an impact at the moment of appraisal, the condition must be considered to be dynamic. According to Kantola, these probable value effects must often be anticipated.

VARTIAINEN (1963, p. 135) claims that the market price of goods corresponds to their exchange or value relations. Though value and price are different concepts, they have a certain similarity. Accordingly, WiIALA (1976, p. 4) suggests that the value of different property items intends to express their significance to the farmer as a means of production. On the other hand, price signifies payments already made, or to be made, for the transfer of a real estate, or monetarized compensation for it. Value and price and their relations have been examined more closely by AHONEN (1970, p. 10-14).

In appraisals of the farm economy, the concept of agricultural land is very common. MĂKI (1964, p. 110) includes in agricultural land all plots that are used for crop cultivation and livestock husbandry. Agricultural land is divided into the following types of land use or farm types: garden, arable land, meadow, and pasture. Except for the soil, different rights and usages belong to it, such as rights to use common land and water areas. Also considered to belong to agricultural land are agricultural building sites and farm tracks, as well as clay, mud and peat extraction sites. The practice followed in the property taxation system in agriculture (ANON. 1967, 34 b §) and in the Finnish official profitability survey differs partly from the concept of agricultural land defined by MÄKI. For this reason, the practice of profitability accounting will be discussed more in detail, together with the presentation of the empirical methods.

In the appraisal of agricultural land, the determination of the relative value must be discerned from the determination of the absolute or the monetary value. The relative value signifies land value compared to the average or 
the best land. On the other hand, the monetary value is based on demand and supply. It can also be based on the impact of a part of property on production activities. On this basis, exchange, capitalized and cost values are determined (e.g. Elstrand and Sønju 1978, p. 20).

GustafsSON et al. (1978, p. 8) consider the capitalized value and the market value, evaluated by using the selling prices of land, as the principal concept of value. Additional concepts of value included in appraisals are: expectation value, sale value and taxable value (VirTANEn 1967, p. 18, Wiiala 1976, p. 3-9). Agricultural appraisals also consider the concepts of use value and cost value (e.g. Elstrand and Sønju 1978, Elstrand 1980, RASMUSSEN 1981).

The capitalized value of land signifies the present value of future returns based on the use of the land (Found 1971, p. 23-24). According to the Association of Finnish Real Estate Valuers (ANON. 1986, p. 16) capitalized value means "present value defined as capital value of the return corresponding to the present use or possibilities of use"'.

According to Gustafsson et al. (1978, p. 9), capitalized value distinguishes between the individual and the mean value. The individual value is based on the profit produced by a real estate which benefits an individual. The latter concept defines the return gained under average circumstances. In addition, the capitalized value can be analyzed according to whether the effects of loans and taxes are taken into consideration in the estimation. Use value is closely connected with capitalized value. Following Elstrand (1980, p. 17), use value can be said to have a broad and a narrow meaning. In the usual narrow meaning, it is considered to be a subjective value resulting from the agricultural use of the real estate or a part of it (compare WIIALA 1976, p. 5-6). Cost value corresponds to the cost occasioned by the production or acquisition of the property or by another action, WIIA LA (1976, p. 40). This method can determine the value of agricultural land, when the clearing costs of the land area are known.

Market price is the indicator of the general exchange value. Market value is defined by the Association of Finnish Real Estate Valuers as current value, or current price, fixed in reference to market prices (ANON. 1986, p. 14). RYYNÄNEN (1967, p. 41) says that, in practice, the average price of land and farms tends to be determined by choosing the largest possible sample of farms for sale or unconstructed areas that have been and will be in agricultural use, and which are typical of the area. Using the prices of such farms and lots, the average unit prices of different land use types can be calculated. Other types of exchange values can also be calculated, for example, market prices paid for land in cases where the real estate is sold for special purposes or where marketing occurs under special conditions (e.g. GusTAFSSON et al. 1978, p. 9).

The main concepts in this study are the capitalized value and the market value. The definition of the contents follows the abovementioned definitions used in the vocabulary of the Association of Finnish Real Estate Valuers. Supplementary arable land means arable land that has already been acquired or will be acquired and that is used or will be used for agricultural production. Thus, the capitalized value of supplementary arable land is the capitalized value of its additional return, determined arithmetically. The determination and calculation of return and its capitalized value will be clarified in more detail later. Moreover, the market prices of supplementary arable land indicate their market value.

\subsection{Aim of the study}

Land, together with labour and capital, are factors of production that are essential to crop cultivation. From the standpoint of the private economy, agricultural land is often regarded as capital (e.g. Virolainen 1950, p. 25 , МӐKI 1964 p. 68), because creating arable land necessitates investment-like financial sacrifices.

Rapid technological change has permitted 
the management of larger farms with an unchanged labour input (e.g. JoHnston and BISChOFF 1971, p. 124, ToRvela and MăKI 1974, p. 70). Simultaneously, technological change in agriculture has allowed the substitution of arable land by other factors of production, so that the relationships between agricultural land and other means of production can change considerably. Technological change is considered to increase the economic use of different means of production, even if the impacts of the change are not well known (compare GriesBaCH 1966, p. 114-116).

Very often in Finnish agriculture, where small farms are predominant, an increase of arable land is regarded as an essential prerequisite for improving the profitability of farming. The economic results will be improved if the return from supplementary arable land is higher than the costs occasioned by its acquisition and cultivation. The acquisition of supplementary arable land can be expected to improve the profitability increasingly within the limiting effect of the arable land area with respect to other factors of production on the farm (machines, buildings, labor). Yet, it is not profitable to acquire supplementary arable land at all costs.

The principal aim of this study is to determine the capitalized and market values of supplementary arable land in the bookkeeping region of southern Finland during the period 1972-1986. The development of capitalized and market values and their correlations will also be addressed.

The study consists of a theoretical and an empirical part. In the first part, factors influencing the value and price of supplementary arable land are examined. Previous studies dealing with capitalized and market values, as well as their principal methods, will be examined too.

In the empirical part of the investigation, the capitalized value of supplementary arable land is determined by using information from the bookkeeping farms of southern Finland that participate in the official profitability survey in agriculture. The evaluation of the capitalized value is based partly on cross section and partly on time series analysis. Farms specializing in cattle and grain production are evaluated. The agricultural practices of these farms are based, to a large extent, on the exploitation of agricultural land and not on an intensive use of purchased production inputs, as in the case of pig and poultry farming. The study aims to determine the dependence between capitalized value and farm size. Information on the market price of supplementary arable land has been collected from the sale price register of the National Board of Land Surveying and from the statistics of the National Board of Agriculture. On the basis of these price statistics, a general picture is given of the market price development of supplementary arable land, as well as the level to which the capitalized values determined from the bookkeeping farms are compared. 
2. FACTORS INFLUENCING THE VALUE AND PRICE OF SUPPLEMENTARY ARABLE LAND

\subsection{The relative value of arable land}

Climate and soil parameters are of central importance to the growth of all plants, including crop cultivation. In this study, factors connected with the soil are of primary consideration, even though the impact of climatic factors are fully recognized.

The classification of arable land under cultivation can be made by assessing the land according to the physical characteristics of its soil (a point value or index system). Moreover, topographic and climatic factors can be included in the land classification. Other factors, such as the proximity of built up areas, availability of irrigation water, etc., can also have an impact on this classification. In any appraisal, the return already realized can be employed, instead of using only the production potential. According to BuSCH (1969, p. 96), many different criteria serve to classify land. Among them are:

- average yields

- natural vegetation

- characteristics derived from the soil texture and its condition

- different combinations of the above-mentioned criteria.

Appraisals based on the characteristics of the soil are, in practice, preferred to the method based on crop yields, because the intensity of cultivation does not directly correspond to the production potential of the land (Busch 1969, p. 97).
In Finland the relative value of arable land has been used in agricultural bookkeeping taxation and acts of surveying. The relative value can also be used to fix the monetary value of arable land, because relative figures indicate differences between plots. Accordingly, agricultural bookkeeping has used the transformed quantity of hectares of arable land to measure farm size. It is obtained by adding the sum of the arable land and garden areas to the area of meadow and pasture, which have been transformed to correspond to the mean value of the arable land (ANON. 1986 , p. 12). Since 1976 , in the bookkeeping farms, the arable land area in use is considered the farm area.

The determination of the relative value for taxation and acts of surveying is called grading. Grading is considered by WiIALA (1958, p. 19) to be a relative appraisal of farm lots, by which means the distinct objects of appraisal are ranked according to their value by a roughly agreed ratio or grading scale. In certain cases and with certain grading classes, grading corresponds to the land classification.

Kulhia (1943, p. 163) claims that grading must be based on the constant capitalized value of the farm lot. This is achieved by taking into consideration the basic condition of the land and its utilization. Moreover, Aalto (1951, p. 104) argues that when grading arable land according to properties which influence its production potential, the physical and chemical properties, i.e. the foundations of the production potential, must be considered. A summary of the significance of soil textures on land classification and its value relations is shown in table 1 . 
Table 1. The relationship between soil textures and different properties (VUORINEN 1952, p. 422-423).

\begin{tabular}{lccccc}
\hline Soil texture & $\begin{array}{c}\text { Moisture } \\
\text { content }\end{array}$ & $\begin{array}{c}\text { Air } \\
\text { capacity }\end{array}$ & Fertility & $\begin{array}{c}\text { Technical } \\
\text { properties }\end{array}$ \\
\hline Med. coarse sand & 0 & 1 & 0 & 2 & 3 \\
Very fine sand & 3 & 1 & 1 & 3 & 8 \\
Silt & 1 & 0 & 3 & 0 & 3 \\
Heavy clay & 2 & 2 & 3 & 1 & 8 \\
\hline
\end{tabular}

According to the table 1, very fine sand and heavy clay obtain the highest points, and medium coarse sand and silt the lowest. A humus content is essential to site quality, and its increase improves the aeration of silt, improves water retention by sand and facilitates the tillage of mineral soils, as well as reducing the risk of desiccation. Thus, the humus content reduces the differences between soil textures.

The soil structure greatly affects the vitality of plants. Because soil structure is dependent upon both the chemical and biological properties of the soil, the relative value of the soil can be determined by these properties. The decrease in the natural fertility of the soil emphasizes the importance of the physical properties in the measurement of the cultivation value of arable land.

The grade of arable land under cultivation is a reliable expression of its relative quality. Land possessing a high grading value produces higher yields than land of lower quality. This is shown by the interdependence between the quality of land and the average arable land (RYYNÄNEN 1962, p. 123-124 and 131). The quality (quality index) of the investigated arable land and the feed-unit yield determined in a given way, serve to calculate the regression line $y=a+b x$, that gives the production capacity of arable land of each quality class (figure 1).

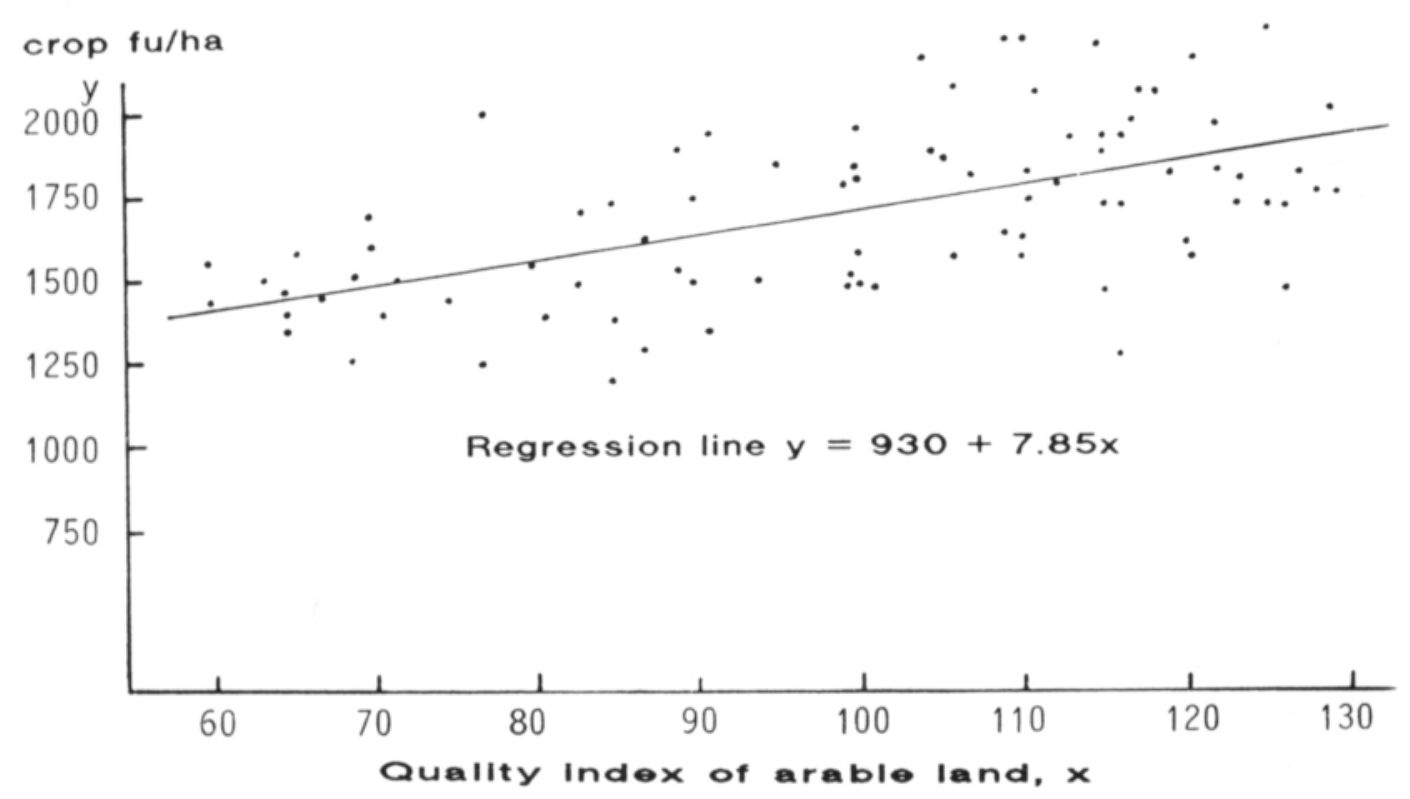

Figure 1. Quality index of arable land and feed unit yield of the investigated farms. 
The estimated regression equation $\mathrm{y}=930+$ $7.85 \mathrm{x}$ means that for the quality index interval (60-133), there was a yield increase of 7.8 $\mathrm{fu} / \mathrm{ha}$ for each one point rise in the quality index of arable land. In this study, the coefficient of regression was statistically significant.

Moreover, the choice of crops can have an impact on yield and, consequently, on the economic return produced by supplementary arable land (Веонм 1966). This depends, in the first place, on the operating margin of the crop on different qualities of arable land. Then, the fixed costs determined by the cultivation of different crops play a central role. The higher the fixed costs of a crop, the sooner will its cultivation become unprofitable on poor soil (figure 2).

In figure 2 root crops are profitable on the best soils. The fixed costs in grain cultivation are lower than in root cultivation. Thus, grain cultivation is possible even on rather poor land. These costs are lowest in extensive pasture cultivation. For this reason, poor soils are the most suitable for pasture cultivation.

According to NositschKa (1973, p. 8182 ), the price of supplementary arable land in West Germany was dependent on its suitability for the cultivation of various crops. If the price of the arable land suitable for pasture cultivation was set at 100 , the ratio of arable land unsuitable for wheat cultivation was 160 , that suitable for wheat cultivation was 171, and that suitable for root crop cultivation was 234. Similar conclusions were also made in Finland on the basis of local land price investigations made by the Department of Agriculture Economics of Helsinki University. They revealed a clear correlation between arable land price and land quality. For example, prices for supplementary arable land in the communes of Elimäki, Iitti and Valkeala, in southeastern Finland, indicated that arable land prices under 100 tax points were less than $70 \%$ of a mean price of the best arable land (>100 points) (MÄKELÄ 1977, p. 36-38). In some communes in southwestern Finland the price of the poorest arable land $(<100$ tax points) was approximately $65 \%$ of the price of the best arable land (131-150 tax points) (Ala-KantTi 1981, p. 41-42).

Though land grading gives a rather reliable picture of soil fertility, it does not signify differences in the economic result derived from different cultivated areas (compare Rothkegel 1952, p. 99). This result is also supported by RYYNÄNEN (1970 p. 21-22) who determines the significance of quality as an explanatory variable of the total gross return. The ratio used for expressing the quality of the soil was the average quality index derived from the taxation classification of arable land. The variable describing soil quality

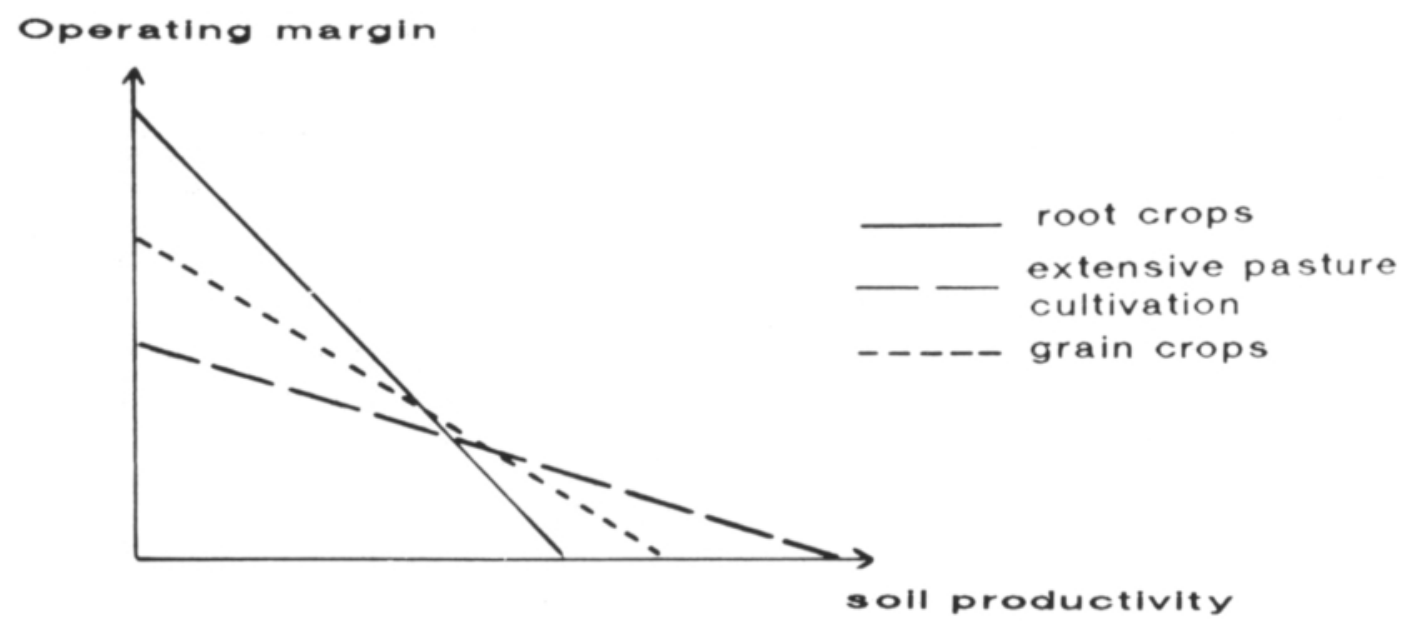

Figure 2. Dependence of operating margin on soil productivity. 
poorly explained the total gross return in the bookkeeping farms in central Finland.

Reichel (1973 p. 29) asserts that the quality of the soil is at present of less importance in the determination of their economic result than it has been in the past. This is due to the increased use of purchased fertilizers, the rotation of crops and other technological measures that raise the production and return of poor soils. Thus, factors related to quality will have less importance in the future, while the significance of technological measures in cultivation practices will increase. Also, cultivation practices and economic development have an influence on the variations of the relative fertility of the soil (BuSCH 1969, p. 97). Soil and climate together determine the fertility of the soil which can nevertheless be analyzed differently depending on the local and economic conditions of each case.

\subsection{Demand for and supply of land}

Initially, land was almost entirely used for agricultural and forestry production. Later, other types of land use arose. Along with socio-economic development, population and industry have expanded into areas traditionally used by agriculture and forestry (ScOFIELD 1957, p. 1503). There have, in fact, been considerable long-lasting changes in land use. According to RENNE (1947, p. 55), seven different types of land use can be identified: agriculture, forestry, mining and quarrying, and areas for waterways, recreation, urbanization and industry.

Reynolds and Timmons (1969, p. 332) consider land demand to be the quantity of land for which users are willing to pay. Land demand includes both direct and indirect, or derived demand. The direct demand concerns land which is used for recreation or logging purposes. Yet, most of the demand is indirect or derived. The derived demand is related to the production potential, location or other qualities of land, but not to the land itself (BARlowe 1958, p. 19). Thus, land demand is the sum of different direct and derived demands.

Agricultural land differs from other goods because of its non-reproductibility. FEUERSTEIN $(1970$, p. 4) showed that wrong conclusions have resulted from the claim that land supply is inelastic to price changes and that land prices are determined only by demand. According to FeUERSTEIN (1970, p. 4), a rising supply function indicates that supply is also expected to increase (compare JøRGENSEN and JøRGENSEN 1971, p. 17). The question then remains whether on the land markets the demanded quantity also has to be smaller and the offered quantity greater when high prices are prevailing than when low prices are prevailing. FEUERSTEIN starts his investigation with an hypothesis that implies that static prices and current prices (indices at the moment of appraisal) are not decisive in land supply and demand, while the expectations of future prices by the suppliers and demanders are decisive.

Land markets in Finland during the 1970's have been characterized by an increasing number of buyers from outside agriculture. As a consequence, competition for land suitable for a variety of uses has increased, especially on the outskirts of population centers (IкÄHEIMO 1979 , p. 27). These areas are characterized by structural changes that are reflected in land use. Moreover, as the population density increases and the demand for land increases, a rise in land price occurs. According to ÄNKÖ (1968, p. 72 ), the price of raw land ${ }^{1}$ increases with increased proximity to the nearest population center. If, in a specific area over half the land area has been divided into lots, the price level of the area will be multiplied by 2.4 , because now it can readily be transformed into developed land.

The certainty that the land will be used for construction purposes tends to increase the price of the land (VIRTANEN 1978, p. 16).

1 Myhrberg (1981, p. 9) defines raw land as mainly unbuilt areas without building plans which is destined to be included in a detailed and systematic planning framework in the near future. 
Along with urbanization, sole agriculture and forestry areas start to have an expectation value, even if it is not definitely known whether the areas will be used for purposes other than for primary production. The value increase of such land is real to a certain extent, because agricultural productivity rises in consequence of, for example, shorter distances to markets. With the advancement of planning, the price of the soil begins to rise more sharply, while the price of the land not planned for construction rises less (VIRTANEN 1978 , p. 18). The greater the certainty about the future use of the land, the higher the land price is.

The demand for various land uses has an impact on price. Land acquisition on free markets places agriculture in a competitive environment, especially near expanding population centers; land prices reflect the consequences of competition.

In figure 3, curve $D_{1}$ describes land demand by farms and curve $\mathrm{D}_{2}$ the demand for agricultural land from outside agriculture, while curve $\mathrm{S}$ represents supply. JøRGENSEN and Jørgensen $(1971$, p. 16) indicate that land demand by farms is more price elastic than the demand for agricultural land from

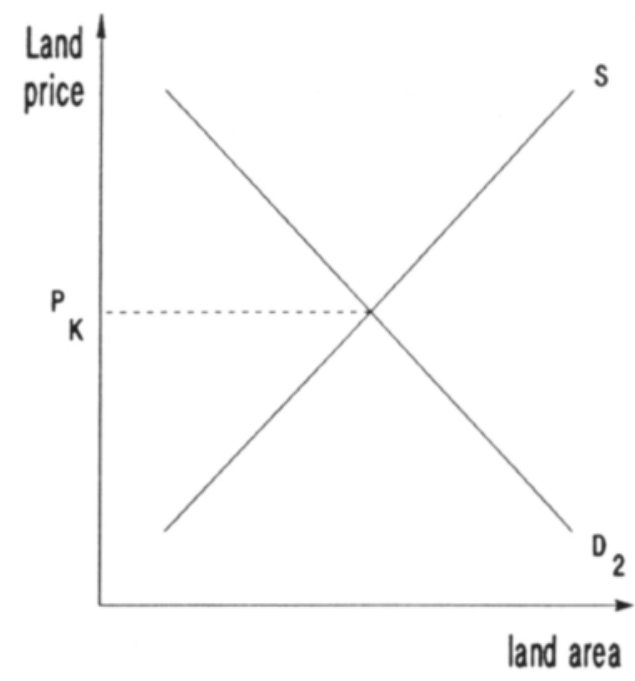

Demand from outside agriculture

Figure 3. Variation of land price by demand group. outside agriculture. If farmers represented all buyers, land price would be at level $\mathrm{P}_{1}$. Correspondingly, if demand from outside agriculture was the only demand on the market, the price would be $\mathrm{P}_{\mathrm{K}}$.

The figure illustrates a situation in which demand from outside agriculture is high. Competition between buyer groups increases the total demand and this forces up the price of land. In areas where agriculture predominates, the demand from outside agriculture can be insignificant, in which case, land price and demand are dependent on competition between farmers. Such schematic cases are not quite valid in reality. In practice, a law concerning land acquisition rights (ANON. 1978) sets limits on the acquisition of agricultural land by non-agricultural interests, in order to guarantee the availability of supplementary arable land.

The land market situation in agriculture changes, not only regionally, but also according to whether land is going to be acquired as additional land or for cultivation on a farm as a discrete economic unit. The acquisition of rather small land areas or lots serve, in most cases, as supplementary land areas. Since the early 1970's, interest in land acquisition has

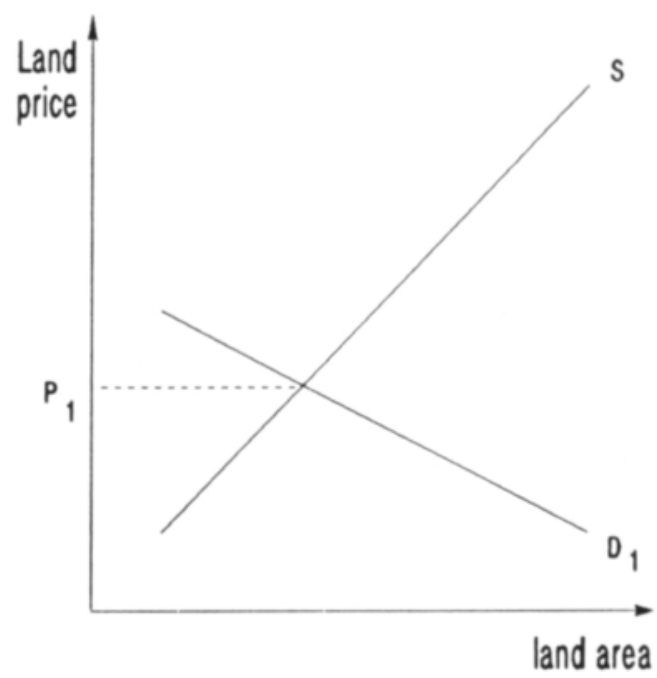

Demand in agriculture 
Table 2. Farmers' willingness to increase area of cultivation in the near future ( 3 years), by agricultural districts.

\begin{tabular}{|c|c|c|c|c|c|}
\hline & $\begin{array}{l}\text { Equiv. } \\
\text { number }\end{array}$ & $\begin{array}{c}\text { Buys } \\
\text { supplem. } \\
\text { arable land }\end{array}$ & $\begin{array}{l}\text { Rents } \\
\text { supplem. } \\
\text { arable } \\
\text { land }\end{array}$ & $\begin{array}{l}\text { Clears } \\
\text { supplem. } \\
\text { arable } \\
\text { land }\end{array}$ & $\begin{array}{l}\text { No plans } \\
\text { at acq. } \\
\text { supplem. } \\
\text { arable land }\end{array}$ \\
\hline $\begin{array}{l}\text { Agricultural } \\
\text { district }\end{array}$ & $\mathrm{N}$ & $\%$ & $\%$ & $\%$ & $\%$ \\
\hline Helsinki Swed. & 25 & 28.0 & 32.0 & 8.0 & 36.0 \\
\hline Helsinki Finn. & 41 & 61.0 & 24.4 & 22.0 & 24.4 \\
\hline Hämeenlinna & 98 & 66.3 & 42.9 & 18.4 & 21.4 \\
\hline Joensuu & 69 & 46.4 & 26.1 & 20.3 & 34.8 \\
\hline Jyvăskylä & 53 & 37.7 & 22.6 & 32.1 & 32.1 \\
\hline Kajaani & 25 & 32.0 & 32.0 & 48.0 & 32.0 \\
\hline Kemi & 18 & 5.6 & 0.0 & 38.9 & 44.4 \\
\hline Kouvola & 94 & 48.9 & 28.7 & 17.0 & 38.3 \\
\hline Kuopio & 126 & 43.8 & 17.8 & 40.4 & 28.1 \\
\hline Mikkeli & 74 & 32.4 & 13.5 & 25.7 & 48.6 \\
\hline Oulu (south) & 44 & 36.4 & 13.6 & 38.6 & 40.9 \\
\hline Oulu (north) & 20 & 35.0 & 25.0 & 35.0 & 50.0 \\
\hline Pori & 75 & 64.0 & 28.0 & 18.7 & 25.3 \\
\hline Rovaniemi & 9 & 33.3 & 22.2 & 22.2 & 33.3 \\
\hline Seinäjoki & 204 & 57.8 & 14.7 & 12.7 & 32.4 \\
\hline Tampere & 65 & 58.5 & 29.2 & 12.3 & 32.3 \\
\hline Turku & 100 & 62.0 & 39.0 & 11.0 & 25.0 \\
\hline Vaasa & 73 & 43.8 & 26.0 & 4.1 & 43.8 \\
\hline Ylivieska & 94 & 41.5 & 12.8 & 28.7 & 33.0 \\
\hline Total & 1327 & 49.4 & 23.7 & 21.7 & 32.8 \\
\hline
\end{tabular}

grown, while the supply of land that has conserved its real value against inflation has remained scanty. A strong drive to buy land predominates on real estate markets (table 2). In a study of a sample of c. 1500 farms which had undertaken generation transfer agreements a strong desire to acquire supplementary arable land was observed (НUHTAMÄKI 1985, appendix 7.2).

According to table 2, willingness to buy was highest in 1985 in the southern districts in Finland, where productive and economic conditions for agriculture are good. Thus, it is evident that demand for supplementary arable land has continued to grow in these regions while, at the same time, willingness to sell land has been low.

\subsection{Technological change}

Yields can be increased if production inputs are increased or if a higher yield can be achieved by the pre-existing inputs. In the latter case, technological change has to be taken into consideration, i.e. production inputs have to be improved in line with production capacity, or innovative production methods and inputs have to be adapted to practice. In economics, technological change is usually defined as a shift of the production function (Hemilä 1983, p. 175). Both terms, technological change (e.g. IHAMUотILA 1971, UPTON 1976) and technical change are used (e.g. ROUHIAINEN 1972, HEerTJE 1977).

Technological change not only appears as a change in efficiency, but also in many other ways (BRown 1968 and Hemilä 1983, p. 176-177). Technological changes in agriculture can be classified according to their biological, mechanical and organizational qualities (Heady 1949, p. 296-297, Отт 1959, p. 302, Willer 1967, p. 116). Weber (1973, p. 57) states that changes in biological technology are a substitute for labour. As for HAYAMI and Ruttan (1971, p. 44), they classify technological change according to its impact in the following way: 
1. Technology as a substitute for labour

1.1. Mechanical technology

2. Technology as a substitute for land

2.1. Chemical technology

2.2. Biological technology

Referring to the classification proposed by HaYAmI and RutTan, technological change has obviously had an impact, not only concerning changes in input-output ratios, but also concerning changes in the combinations of costs of different inputs. For example, the motive for acquiring machines is usually the substitution of labour. With respect to economic theory this is reasonable when the price ratios of inputs change so that the minimum combination of the costs in question also change. In figure 4 , a schematic view of the impact of changes in price ratios on costs is presented (KeHRberg and ReISCH 1969).

Curve TT' shows different $x_{1}$ and $x_{2}$ inputs which produce the same yield. Lines $P_{1}$ and $\mathrm{P}_{2}$ describe the costs generated by these inputs when the relative prices of inputs are different. If the price of labour $\left(\mathrm{x}_{1}\right)$ rises in relation to machines $\left(x_{2}\right)$, the relative input curve $P_{2}$ changes directly to curve $P_{1}$. In this way, the substitution of labour by machines becomes reasonable. The production optimum then moves from $Q_{1}$ to $Q_{2}$. Correspondingly, the same situation predominates in grain cultivation where the use of chemical and biological technology can reduce the area of arable land used for the production of a required yield. The prices of the inputs involved also determine the most advantageous use of the

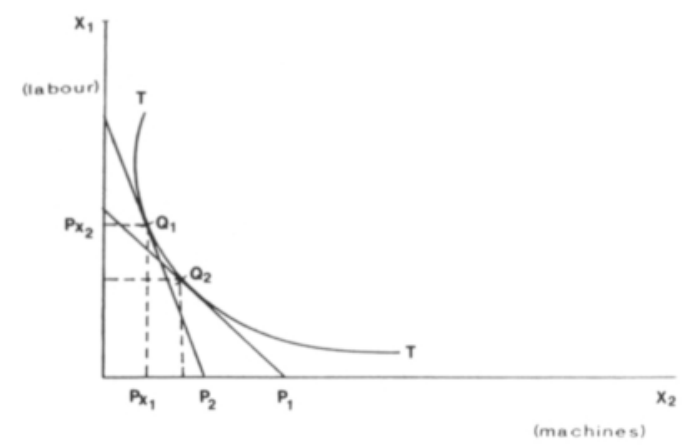

production inputs, as will be discussed later in a calculation scheme.

HerdT and Cochrane (1966, p. 243-263) have dealt with technological change and its impact on the price of arable land. They used a model based on the theory of the firm and applied it under conditions of perfect competition. Figure 5 shows cost curves for a firm with two variable inputs, and one fixed input. Labour and capital represent variable production inputs while land represents a fixed means of production. Average revenue and marginal revenue equal the price-support level OD.

Assuming that the firm begins at a long-run no-profit equilibrium it operates at point $\mathrm{A}$ on $\mathrm{AC}_{1}$. At that point, its marginal cost equals its marginal revenue, and average costs are at a minimum.

With technological change, unit costs are expected to decrease, in which case cost curves are shifted to the level $\mathrm{AC}_{2}$ and $\mathrm{MC}_{2}$. The profit of the firm would then be ABCD. The maximization of profit in the short run brings the firm to the point A', where marginal cost equals marginal revenue. At $A^{\prime}$ the firm produces the quantity $\mathrm{q}_{2}$, average costs being at the level OE, resulting in a profit A'FED. If the firm were still bigger, the average cost curve would be $\mathrm{AC}_{3}$ (constant returns to scale). It could then produce the same quantity of products at the lower costs OC. Profit would then be A'GCD. This kind of situation encourages the firm to buy more land so that average costs would attain the level $\mathrm{AC}_{3}$. As young farmers tend to increase their income by implementing the latest technology, while at the same time expanding their activities, land prices consequently increase. As a result, the average costs of both the individual firm and other firms rise, first to the level $\mathrm{AC}_{4}$ and then to the level A", described by the curve $\mathrm{AC}_{5}$. If technological development is expected to continue, it would increase the expected income in agriculture. At the same time, competition on available land leads the individual firm and other firms into a situation in which no profit is gained from produc-

Figure 4. The minimum cost with different price ratios. tion activities. 


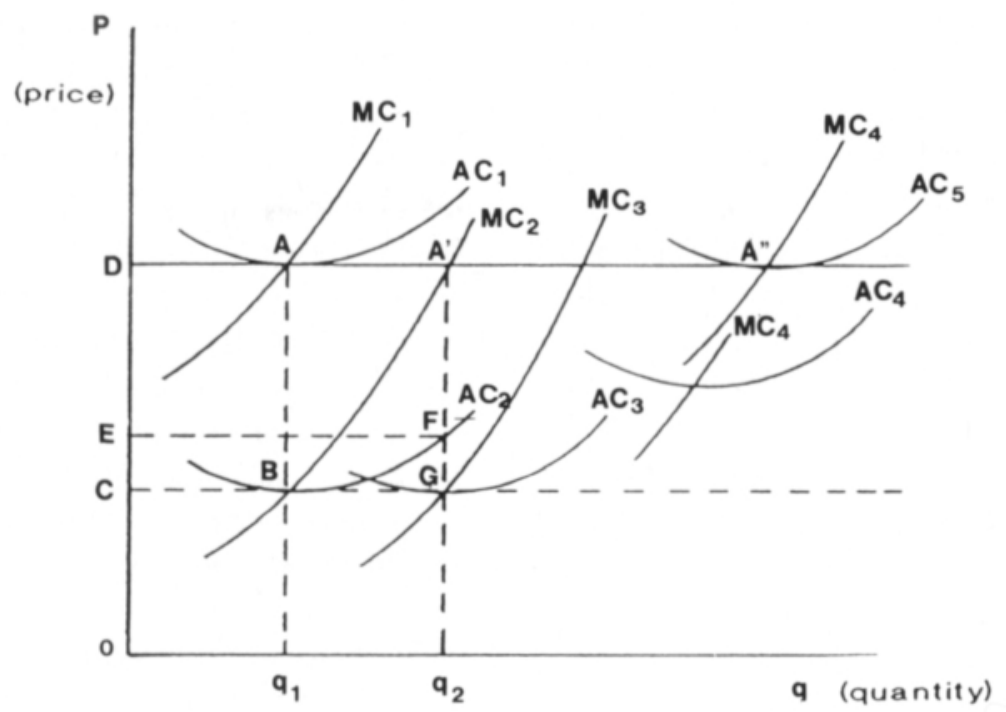

Figure 5. Theoretical model describing the development of land price.

The effect of technological changes on the price of arable land can be examined on the basis of the neoclassical theory of the firm. The basic assumption is that the firm operates under conditions of perfect competition. The principal element of perfect competition is that producers and consumers are unable to affect product prices. The same argument applies to the input market. According to Koutsoyiannis (1985, p. 154-155), the basic assumptions of the neoclassical theory of the firm are as follows:

- the buyers and sellers are sufficiently numerous

- the marketable product is homogenous

- firms have the right to enter or leave the market

- the main aim of the firm is profit maximization

- the market is not regulated.

For perfect competition, there should also be:

- perfect information on markets

- market balancing prices are instantaneous

- the sale of products and means of production occur without transfer costs.
Also assumed is the perfect physical transferability of the means of production and flexibility between types of farming.

How well does this concept of perfect competition as embodied in the theory of the firm apply to agriculture? The prices of agricultural products are arrived at in Finland on the basis of negotiations between the producers and the state. The agreed prices are, according to MÄKINEN (1988, p. 26), equilibrium prices over which the producers have no control. On the other hand, in the middle of the 1970's, the state introduced regulations concerning the establishment of large production units and the expansion of livestock production. The subsequent establishment of quotas, are partly at odds with the assumptions of the theory. This is examined in more detail when the results of the investigation are discussed.

The other preconditions of perfect competition are met fairly well by the firm level. Producer prices are known before the start of the production season, and expectations concerning price developments are quite stable because of the Farm Income Act. Consequently, the marketing of agricultural products does not generally involve risk, whereas production 
risks arising from environmental factors are real. Further, transaction costs in deals concerning means of production are not able to be considered. This is certainly the case with respect to transactions concerning land.

The impact of technological change on the price of agricultural land can be examined analytically. It is assumed that profit maximization starts at point $\mathrm{A}$. The marginal value product of land is $\mathrm{MPP}_{\mathrm{M}}$, the marginal value product of labour $\mathrm{MPP}_{L}$, the marginal value product of capital $\mathrm{MPP}_{\mathrm{K}}$, and the market price of the product $\mathrm{P}_{\mathrm{Y}}$. As the result of profit maximization, the following equation is obtained:

$$
\frac{M P P_{M}}{P_{M}}=\frac{M P P_{L}}{P_{L}}=\frac{M P P_{K}}{P_{K}}=\frac{1}{M C_{y}}=\frac{1}{P_{y}},
$$

in which $\mathrm{P}_{\mathrm{M}}$ is land price, $\mathrm{P}_{\mathrm{L}}$ price of labour, $\mathrm{P}_{\mathrm{K}}$ price of capital, $\mathrm{MC}_{\mathrm{y}}$ is the marginal cost of the product $\mathrm{y}$, and $\mathrm{P}_{\mathrm{y}}$ is the price of the product $\mathrm{y}$.

Technological change is assumed to be neutral, i.e. technological change increases the marginal value product (MPP) of each input in the same proportion. Thus, costs fall to the level described by the curves $\mathrm{AC}_{2}$ and $\mathrm{MC}_{2}$ (figure 5). Production temporarily remains at point $\mathrm{B}$. This change does not influence the prices of inputs and outputs (products) because they are exogenous. Instead, it results in a decrease of marginal costs. It can be expressed schematically as follows:

$\frac{M P P_{M}}{P_{M}}=\frac{M P P_{L}}{P_{L}}=\frac{M P P_{K}}{P_{K}}=\frac{1}{M C_{y}}>\frac{1}{P_{y}}$.

To obtain a state of equilibrium, more labour and capital could be used in the short run. This results in a decrease of the marginal value product and in an increase of the marginal cost, until the following situation (point $\mathrm{A}^{\prime}$ ):

$\frac{M P P_{M}}{P_{M}}>\frac{M P P_{L}}{P_{L}}=\frac{M P P_{K}}{P_{K}}=\frac{1}{M C_{y}}=\frac{1}{P_{y}}$.
The total output increases while prices remain constant. In the long run, the firm has an incentive to acquire more land, until the marginal value product of the land decreases or land price increases. If several firms expect the same situation and seek to acquire land, land prices will rise. Thus, the individual firm, as well as other firms, will drift into a situation (A') where there is no profit.

Herdt and Cochrane (1966, p. 245-248) claim that such a model presupposes some requirements essential to agriculture: land price rise, rapid and wide-spread technological changes, reduction of the quantity of total labour, continued increase in output, expanding activities of firms, and increase in farm income despite the fact that the income per production unit derived from farming remains constant or falls.

Technological change in Finnish agriculture manifests itself not only as a general intensification of production, but also as a growth in the use of factors and inputs of production acquired from outside the farm. Consequently, the capital stock per farm has considerably increased (IнамuотіLA 1983, p. 97). At the same time, the contribution of agricultural land to capital stock in agriculture has continuously increased during the 1960's and 1970 's, to reach $41.2 \%$ in 1980 , at current prices (Ihamuotila 1983, p. 100). The significance of agricultural land is, thus, central to agricultural practices in Finland, in spite of the utilization of machines as a substitute for labour, and chemical and biological technology as substitutes for land.

\subsection{Other factors}

The price of supplementary arable land depends on many factors, but its determination and quantification is problematic because the annual sales of land represent only a minor part of the total agricultural land area. Demand applies, in the first place, to lots of arable land and forest. The changes in farm ownership usually occur as transfers between 
parents and children, in which case the prices of farms are considerably lower than the prices of supplementary land.

The price of additional land, as well as that of agricultural land, as parts of a whole farm, are influenced by all those factors that arise from agricultural practices, its organization and profitability. МÄKı $(1964$, p. 143) has classified these factors as follows:

1. General factors having an effect on land values in certain regions.

2. Factors having an effect on the value of an individual farm.

3. Factors having an effect on the value of an individual plot.

To determine the conditions of appraisal of a certain area, the average price level of agricultural land in that area must be assessed. Several different factors are implied, among which the most important are, according to Ryynănen and PölKki (1982, p. 71):

\section{Climate}

2. Land fertility

3. Location and the economic and technical development of the agricultural environment

4. Agricultural produce marketing and price relations

5. Availability of labour

6. Aesthetic quality of the area

7. Possibilities for education and recreation

8. Other factors

With most of these factors their effect on land value cannot be clearly identified. Their effect appears as a price level, to which parts of a farm can be compared. At the same time, it is necessary to determine the average price level of different land use types in the evaluated area, before an evaluation concerning an individual farm or plot can be accomplished.

VIRTANEN (1979, p. 58) divides the factors influencing land value according to their nature into physical, juridical and market fac- tors. Among the physical factors are soil and topography. Juridical factors include plans or other regulations that indicate how a realestate must be employed and what buildings are permitted. The most typical market factors are demand and supply and the local price level.

JøRGENSEN and JøRGENSEN (1971, p. 9-15) divide the factors influencing land price into three groups: general factors, quality factors, and individual factors. The main features of this grouping are shown in table 3 .

Table 3. Factors influencing the price of agricultural land.

\begin{tabular}{|c|c|c|}
\hline General factors & Quality factors & Individual factors \\
\hline Inflation & Quality of the soil & \multirow{3}{*}{$\begin{array}{l}\text { Buyer's conception of } \\
\text { the location of the } \\
\text { farm and its } \\
\text { suitability for } \\
\text { different usages }\end{array}$} \\
\hline \multirow{2}{*}{$\begin{array}{l}\text { Possibilities of } \\
\text { making a living } \\
\text { in agriculture }\end{array}$} & Size of the farm & \\
\hline & $\begin{array}{l}\text { Relations between } \\
\text { plots }\end{array}$ & \\
\hline $\begin{array}{l}\text { Possibilities of } \\
\text { making a living } \\
\text { elsewhere }\end{array}$ & $\begin{array}{l}\text { Location of the } \\
\text { farm }\end{array}$ & $\begin{array}{l}\text { Buyer's and seller's } \\
\text { conception of the } \\
\text { possibilities of making } \\
\text { a living }\end{array}$ \\
\hline \multirow{2}{*}{$\begin{array}{l}\text { General interest } \\
\text { rate and infla- } \\
\text { tion and gene- } \\
\text { ral economic } \\
\text { activity }\end{array}$} & & Wealth of the buyer \\
\hline & & $\begin{array}{l}\text { Willingness to retire } \\
\text { or continue farming }\end{array}$ \\
\hline Number of farms & & $\begin{array}{l}\text { Seller's age and family } \\
\text { situation }\end{array}$ \\
\hline $\begin{array}{l}\text { Measures of pub- } \\
\text { lic authorities }\end{array}$ & & \\
\hline
\end{tabular}

The relation between the variables affecting land price can be very complex, especially between the general factors. The distinct effect of each of the contributing factors is difficult to define. Jointly, the factors contribute to the conditions in each area and to the possibilities of making a living in agriculture and, thus, to the price level of land. Moreover, there are interrelations between the main groups which affect the individual factors influencing the ability to make a living from agriculture,

According to WiIALA (1976, p. 90), the most important factors related to the value of 
an individual lot of arable land are the following:

1. Natural fertility

2. Local position

3. Size of the field

4. Shape and other factors related to value

These factors have an impact on the yield derived from arable land and, consequently, on land price. In particular, roads and population centers contribute to fluctuations in land price. CROWLEY (1974 a, p. 7) has argued that the proximity of highways does not have an impact on land price. Similarly, he argued that the location of population centers in relation to the sold land does not have an effect on land price.

Virolainen (1950, p. 160-177), on the other hand, has presented evidence to suggest that accessibility has an effect on the relative value of arable land. The further the arable land was located from population centers (e.g. Helsinki, Turku, Tampere, Lahti, and Mikkeli), the lower was its relative value. NositSCHKA $(1973$, p. 91-95) has shown that the location of the land with respect to the road network has an impact on its price. The price rise was explained as a consequence of an expected increase of land value in anticipation of its use for construction purposes near population centers.

Hovi and JOKINEN (1974, appendix 8/14), following the methods developed by Kantee, have calculated transportation costs per hectare in different cultivation tasks, arising from the distance between the field and the farmstead. The following figures show the transportation costs per hectare arising from the cultivation of different sizes of field, in relation to their distances. Costs are represented by an interval between a minimum and a maximum cost, calculated according to the quality of the road:

\begin{tabular}{ccc}
\hline $\begin{array}{l}\text { Distance from the } \\
\text { farmstead } \mathrm{km}\end{array}$ & $\begin{array}{c}\text { Field size } \\
\text { ha }\end{array}$ & $\begin{array}{c}\text { Transportation } \\
\text { costs FIM/ha }\end{array}$ \\
\hline 1 & 1 & $35-50$ \\
1 & 3 & $20-39$ \\
1 & 10 & $18-35$ \\
3 & 3 & $40-137$ \\
8 & 3 & $114-316$ \\
8 & 10 & $101-284$ \\
\hline
\end{tabular}

There is a tendency to acquire additional land at the shortest distance possible from the farmstead, following which the additional area to be bought is often bordering the arable land of the purchasing farm. Because of the increase in arable area, cultivation costs per unit area decrease. Thus, with respect to additional land, the distance of the fields from the farmstead does not influence the transportation costs as significantly as HOVI and JOKINEN claimed. This contention is supported by NositschKa (1973, p. 103-105) who observed that such costs did not raise prices in transactions which contributed to improvement of the organization of plots. The effect of the distance between the farmstead and fields on the organization and profitability of agriculture and, consequently, on the prices paid for land, are demonstrated by the following figures. When purchased lots were divided in groups according to the distance between the farmstead and fields, the average price paid per hectare of arable land decreased with increasing distance from the farmstead:

\begin{tabular}{lc}
\hline $\begin{array}{l}\text { Distance from the } \\
\text { farmstead } \mathrm{km}\end{array}$ & Average price DM/ha \\
\hline under 1 & 18620 \\
$1-5$ & 16350 \\
over 5 & 11400 \\
\hline
\end{tabular}

Purchasers were willing to pay $60 \%$ more for arable land near the farmstead than for arable land at a distance of more than $5 \mathrm{~km}$. 


\section{PREVIOUS STUDIES BASED ON THE CAPITALIZED AND MARKET VALUE APPROACHES}

\subsection{Studies based on the capitalized value approach}

\subsubsection{Basic principles for the determination of capitalized value}

The value of arable land is based on returns derived from it. For the appraisal of land value several models have been constructed which show possible variations or stability of returns annually derived from land (e.g. NIEhans 1966, Reynolds and Timmons 1969, Gustafsson et al. 1978, Aalstad et al. 1979). Common to these models is that land value is based on the capitalization of returns derived from land in the future. In their simplest form the models suppose that returns are expected to remain unchanged indefinitely. Thus, land value $\mathrm{V}$ is determined as follows:

$\mathrm{V}=\mathrm{R} / \mathrm{r}$, in which $\mathrm{R}=$ return from land and $r=$ interest rate.

Land value increases with both increasing return and decreasing capitalization rate. With low interest, even a small capitalized return indicates a high land value, and vice versa. According to MÄKı $(1964$, p. 107), the difficulties related to the assessment of expected returns result in a more significant error than the method of appraisal itself. FeUERSTEIN (1970, p. 75-77) criticizes the above model because of its fixed return and unchanged interest. He tried to demonstrate, using various appraisal methods, the unsuitability of the model for expressing the average exchange value of real estates in agriculture and for- estry. Crowley (1974 b, p. 54) admits that the model can only be used in situations where the investment period is either infinite or of very long duration.

The capitalized value has been severely criticized when used for the determination of the value of arable land or of a farm as a whole. Aereboe (1919, p. 244-256) already doubted whether the gross return and costs can be assessed correctly and accurately in practice. Often the determination of commodity prices remains uncertain, as does the interest rate to be used in the appraisal.

Huelm (1952, p. 2) emphasizes the theoretical character of capitalized value which is, in principle, an important factor in the determination of the market value of a real estate, but is difficult to express numerically. ELSTRAND and SønJu (1978, p. 32) show that the capitalized value of arable land depends on the following factors:

a) Yield level

b) Production efficiency

c) Type of farming

d) Personal characteristics of the farmer.

Elstrand and Sønju (1978, p. 42-56) stress the importance of inflation and the interest derived from alternative investments, in the choice of the interest rate to be used in appraisals of capitalized value. KAARLEHTO (1954, p. 67), on the other hand, considers that the determination of commodity price levels is one of the most difficult tasks in the income approach; the factors having most influence on the price development are general economic conditions, of ficial agriculture policies, plant breeding, weather, production 
quantities, marketing conditions, and specialized commodities.

The capitalized value approach has been little used even for the determination of the value of lots (Kanerva 1978, p. 9-12). The reason for this has been the low real interest on loans and the rise of the real prices of lots. The real interest, i.e. the difference between the average interest on deposits and the depreciation of the value of money, was approximately $-2.2 \%$ during the period 19631977. If the loan capital is invested in schemes that conserve their real value, the borrower can benefit. Concerning land sales, capital gain is a commonly used concept (e.g. REYNOLDS and Timmons 1969, p. 331, Plaxico and KletKe 1979, p. 327-330, CAStle and Hoch 1982, p. 8-18). Thus, the rising value of arable land is a capital gain rather than a direct income to the landowner. During a period of rising land values, it seems reasonable to hypothesize that the anticipated appreciation of land values (expected capital gains) has had an impact on land value. Consequently, a person acquiring land might have been more interested in the financial organization of the agreement than in the appraisal of the capitalized value.

Capitalized value depends essentially on the choice of the interest rate used in capitalization. Several researchers emphasize the importance of the choice of the right interest rate when assessing land value. VIROLAINEN (1950, p. 33) claims, on the basis of work done in the U.S.A., that the taxable net return has to be capitalized at an even higher interest rate than the industrial dividends given to invested capital. NieHans (1966, p. 195) emphasizes the importance of the characteristics of investment projects in the determination of the interest rate. Then, the degree of liquidity (a risk related to the investment project), the alternative use of capital, and the loan interest must be taken into consideration. SCOFIELD proposes that "the rate should represent the prevailing opportunity cost of capital as determined by the rate of return, after taxes, that could be realized from other investments having the same liquidity and risk characteristics as farmland". According to him, "nonfarm income-producing real estate such as apartments and office buildings and common stocks are most clearly comparable to farmland in an investment sense"' (SCOFIELD 1965 a, p. 101).

Elstrand and Sønju (1978, p. 43-56) present five different cases for the determination of the interest rate. As well as the previously presented views on this subject, they emphasize the usefulness of both the long term and real interests for land property when assessing agricultural investments. Accordingly, the choice of the interest rate for assessment affects the assessment's applicability.

\subsubsection{Land value based on rent}

In economics, land used for cultivation has been given considerable attention. The part of the total gross return from the soil paid to the landowner for his use of this original and indestructible force, has been termed economic rent by the English economist RICARDO (ref. GonNER 1891). However, Ricardo does not regard the return from land due to soil improvement as economic rent. According to Ricardo, economic rent is a residual income that is left over for the landowner, after the costs of the other production factors have been substracted from the total gross return. The formation of economic rent on soils of different qualities is based on the decrease of soil fertility along with population growth, because the supply of arable land is limited while, at the same time, demand for it grows. The best soils are cultivated first, then the poorer soils. The last soils put to agricultural use give a return that is equal to compensation for labour and capital, and so produce no economic rent at all.

The teachings of Ricardo have been sharply criticized. CAREY (ref. ABEl 1958, p. 314) tried to prove that the best soils are not put to use first. Rather, soils that are easy to bring into cultivation, but which do not necessarily produce the highest yield compared to the best 
soils, are employed first. Equipping labour with new machines results in an increase in the labour contribution to the total gross return and, correspondingly, in a decrease in the economic rent. This is contrary to the thoughts of Ricardo. Carey thus gave a new dimension to the theory of economic rent, namely the impact of technological development. The divergence of opinion between Ricardo and Carey was due to the difference in their conceptions of "better soil".

von THÜNEN (1921, p. 106) also brought a new concept to the theory of economic rent, namely the interest derived from the location of agricultural production with respect to the markets. According to von Thünen, the location of the commodity market has an effect on economic rent. Farmers practicing near a market obtain the same price for their products as farmers practicing further away, despite the penalty of extra transportation costs. The benefit, measured in monetary terms or in crops, is economic rent.

Several researchers, e.g. Marshall (1920), Clark (1923), and Cassel (1938) were favourable, like Ricardo and von Thünen, to "the theory of differential rent", This kind of rent was supposedly generated when soils of different fertility were put to use. The intensity and location of production, in relation to the market place, were considered to have an effect on differential rent.

The determination of economic rent is not simple, because economic rent has a double significance (CASSEL 1938). The costs generated by land use (e.g. rent on land, interest on capital) are often included in the cost calculations of the production unit and are reflected in the prices of produced goods. On the other hand, the landowner's return from land (e.g. rent on land) is economic rent. Referring to figure 6, VARTIAinen (1963, p. 149) states that when elucidating the theory of price formation and the compensation for production factor costs, if only a limited quantity of a production factor is available, for example the soil, its supply curve is vertical. Price has no effect on supply.

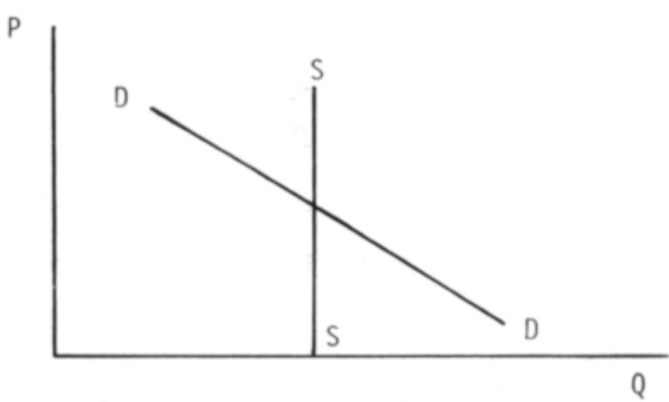

Figure 6. Effect of demand and supply on the price and quantity of a production input.

The price to be determined for the production input is then called interest or economic rent, because its market price depends solely on demand which, in turn, depends on the prices of the final products produced by the input. Economic rent is then price-determined, or the price is determined by the price of the final product. On the other hand, if economic rent is included in production costs, it is price-determining.

As well as in economics, rent has also been considered in the theory of agricultural appraisals (e.g. Aereboe 1919, p. 117-199, Laur 1930, Neukomm 1947, p. 64-65). According to Virolainen (1950, p. 25), economic rent is the part of the taxable net return that can be used as interest on land, irrespective of whether the capital is initial or produced (real). According to Virolainen, the national economic theory of value, as such, does not apply to agricultural appraisals. In a private economy, the division of the taxable net return between economic rent and real capital is irrelevant.

YLÄTALO (1978) determined the capitalized value for whole farms, employing the bookkeeping farms of southern Finland. Two types of farms were considered: cattle farms and grain farms. The farm family income was divided into return from labour and return from capital according to the ratio of labour and capital inputs used in production. The return from capital was further divided into re- 
turn derived from land, and return derived from capital other than land, according to the ratio of the parts in question. The return from land determined in this way was called economic rent. Land value was assessed by capitalizing the economic rent for an unlimited period, using an interest rate of $3 \%$. The land value of farms on which arable farming predominated was $2-3$ times higher during the investigation period $(1968-1972)$ than the land value of farms on which livestock farming predominated.

Among recent studies in Finland, HeISKANEN $(1983,1987)$ studied the determination of the value based on the grading of agricultural and forest land. He aimed at determining the capitalized value of agricultural land and forest, because according to the legislation concerning division surveys, agricultural lands and woodlands must be graded, based on their yield. The calculation of the capitalized value of agricultural land in Heiskanen's investigation was accomplished using the results of bookkeeping farms in 1983. Even if the results of one year were not highly conclusive, it was evident that the grading value of the average agricultural land in southern and southwestern Finland was 80 points, and in the "blueberry type" forest it was approximately $45-50$ points (HeisKanen 1987, p. 66). Thus, according to the grading, one hectare of agricultural land corresponded to about $1.6-1.8$ hectares of forest.

LAURILA (1988) has also examined theories of economic rent and their suitability for explaining price formation. The aim of the study was to construct a model for the determination of the market price, in which price was explained by factors both exogenous and endogenous to agriculture. The linear regression model Laurila used in the study explained $67 \%$ of the variation of the market price of arable land. Factors within agriculture, such as market activity, profitability in agriculture, quality of the arable land and crop yields explained $63 \%$ of the variation, while $4 \%$ was due to exogenous factors.

\subsubsection{Determination of the value of supplementary arable land by the residual approach}

The value of supplementary arable land has traditionally been determined in agricultural economics by the residual approach, where the return or income from additional land is examined as a residual from land. When the costs of other factors and inputs of production are subtracted from the gross return, the residual indicates the economic compensation for additional land. Typical to the residual approach are certain concepts of economic results, used for the determination of the value of supplementary arable land which will be examined later.

According to RYYNÄNEN (1978, p. 15-17), the profitability of acquiring supplementary arable land should be considered ultimately on the basis of surplus of taxable net return. The taxable net return shows that part of the gross return which remains as interest on invested capital. By reference to this, a farmer acquiring additional land can determine whether he will obtain sufficient interest on the capital invested in land acquisition and whether he can still make a profit. With an increase of the arable land area, the gross return and operating costs rise. The difference between the gross return and operating costs provides an indicator of the surplus of return derived from the increase of arable land area. This difference is also the interest on the capital invested in land acquisition. The capitalization of this difference, according to the current interest rate, gives the capitalized value of the increase of the acquired arable land.

The increase of return can be determined for a farm as a whole or for the additional area. The net return of the additional area can be determined by subtracting the increased cultivation costs from its gross return. In this case, changes in other production activities on the farm are not taken into consideration. Instead, only a part of the increase of the net return of the farm as a whole can be attributed to return derived from land. The re- 
Table 4. Taxable net return (FIM/ha) on the profitability survey farms of southern Finland, by size of farm. Average figures during 1972-1986.

\begin{tabular}{|c|c|c|c|c|c|c|}
\hline \multirow[t]{2}{*}{ Year } & \multicolumn{6}{|c|}{ Taxable net return ${ }^{a}$} \\
\hline & $<10$ ha & $10-20$ ha & $20-30$ ha & $30-50$ ha & $>50$ ha & Average \\
\hline 1972 & -651 & -24 & 188 & 301 & 379 & 204 \\
\hline 1973 & -926 & -266 & 9 & 180 & 284 & 57 \\
\hline 1974 & -1134 & -94 & 124 & 403 & 522 & 253 \\
\hline 1975 & -1178 & 15 & 480 & 608 & 813 & 504 \\
\hline 1976 & -1741 & -220 & 482 & 748 & 981 & 542 \\
\hline 1977 & -2262 & -854 & -102 & 116 & 53 & -114 \\
\hline 1978 & -2176 & -839 & -93 & 194 & 330 & -38 \\
\hline 1979 & -2469 & -827 & -67 & 488 & 394 & 103 \\
\hline 1980 & -2856 & -733 & 408 & 975 & 1482 & 754 \\
\hline 1981 & -3472 & -1015 & -69 & 501 & 634 & 193 \\
\hline 1982 & -2267 & -321 & 812 & 1869 & 2129 & 1472 \\
\hline 1983 & -738 & 737 & 1271 & 2359 & 2957 & 2152 \\
\hline 1984 & -1453 & -78 & 916 & 1635 & 2173 & 1474 \\
\hline 1985 & -2022 & -339 & 635 & 1719 & 1798 & 1284 \\
\hline 1986 & -1674 & -398 & 921 & 1815 & 2316 & 1573 \\
\hline
\end{tabular}

Source;

a Current Topics in Agricultural Economics. Results of the bookkeeping farms, business years 1972 - 1986.

mainder is due to a more intensive use of production factors. However, the division of the net return between land and other parts of the farm is difficult in practice (e.g. Ylätalo 1978 , p. 27-35). Moreover, according to the profitability survey in agriculture, the average taxable net return in agriculture remains negative in small farms (table 4).

From table 4 it can be concluded that the taxable net return depends on the size of the farm. Yet, other factors have an impact on income, such as the farmer's managerial ability, differences in labour efficiency, different uses of production factors, and possible other activities. It is also probable that farmers' perceived incomes are quite different. For example, the farmer of a smaller farm practicing intensive livestock husbandry may consider his farm to be at most a working place, and his income is perceived principally as income from work, despite a considerable amount of capital he may have tied-up in the enterprise. In larger farms, farmers pay more attention to interest on capital than to income from work. Accordingly, taxable net return would be more suitable as a criterium for assessing the profitability of acquiring additional land on large farms than on small ones.
LOCKEN et al. (1978, p. 55-57) also addressed the main problem of applying the residual approach, namely the pricing of labour. They pointed out, with empirical examples, that the residual income and, thus, the capitalized value varied according to whether or not the farmer's work was priced:

1. Based on the average labour costs of external labour.

2. According to 1 , increased by the entrepreneur's management costs.

3. Leaving labour totally unpriced.

The annual average capitalized value is naturally the highest in case 3 , the second highest in case 1 , and the lowest in case 2 (LOCKEN et al. 1978, p. 56). Other studies on the use of the residual approach have been examined more closely by e.g. CLARK (1973) and Doll et al. (1983).

In assessing the return from land, difficulties arising from the pricing of labour can be avoided by leaving labour unpriced, in which case the residual signifies the gross margin on labour and capital cut off from the gross return. The calculation of these assessments with respect to the operating margin is based on the hypothesis that the farm possesses rele- 
vant production factors (land, buildings, labour) for agricultural practices. Some of these factors have been planned over decades and so their costs are of long duration. Since the costs generated by these production factors do not change considerably, when the extensiveness of production maintains a parity with the capacity of the factors of production, they are called fixed costs (e.g. WestermarCK 1967, p. 9-11, Elstrand 1980, p. 114). If more arable land is acquired for the farm, the fixed costs induced by buildings, equipment and labour remain almost unchanged, in which case the unit costs per hectare decrease when the area increases.

Variable costs are those that increase or decrease along with the extensiveness of production. These costs consist of, e.g. costs for extended crop cultivation (purchased seed, fertilizers, plant protection, operating costs of equipment, veterinary costs, feed purchases, and energy costs). The subtraction of the variable costs from the gross return gives the residual for covering the fixed costs. This residual, or operating margin, includes the possible profit derived from production activities.

When assessing the growth of the operating margin resultant upon the increase of a farm's arable area, the operating margin of the coming years must be determined. The assessments have to be based on past returns. According to RYYNÄNEN (1967, p. 49), return must be assessed as a mean value of several years, because weather conditions result in annual variations of the agricultural yield.

\subsubsection{The value of supplementary arable land based on its marginal productivity}

Real estate as a whole possesses a definable value. If supplementary arable land is acquired, the value of the real estate will change. When supplementary land is acquired by an existing farm, there will be a need to assess its significance to the farm complex as a whole, i.e. the farm value must be appraised with and without the additional land. The value obtained in this way is called the differential value (RYYNÄNEN 1967, p. 25). The aim is not to determine the value of arable land based on the average return of the farm, but rather to apply the concepts of marginal value product and marginal productivity ${ }^{1}$. LARSSON (1954, p. 68) and WiIALA (1960, p. 86) have used the concept of marginal value to mean land value based on marginal value product or marginal productivity.

According to Barlowe (1958, p. 159160 ), compensation for land can be examined using the economic rent. Economic rent was defined by BARLowe (1958, p. 150) as the residual obtained after the minimum compensation to attract the factors into production was subtracted from the return. It can be determined by using a production function if marginal and average unit costs induced by production activities are known. Barlowe (ibid.) showed that it is profitable for the entrepreneur to increase production to the point where the marginal value product and marginal cost are equal. The economic rent, obtained by the entrepreneur, is then equal to the average unit return (price of the product) when the average costs of these units have been subtracted and multiplied by the quantity of units. This can be presented by cost curves derived from the production function (figure 7).

BARLOWE (1958, p. 160-163) stated that the analysis of marginal productivity is able to show differences in economic rent arising from differences in land quality, location in relation to the market place, and transportation costs. The operating margin on fixed costs of the enterprise may be considered as economic rent. When the costs of fixed pro-

1 In a state of economic equilibrium the production factors are allocated a compensation corresponding to their marginal value product, i.e. the compensation for the factor of production $\mathrm{X}_{\mathrm{i}}$ is:

$\frac{\Delta Y_{i}}{\Delta X_{i}} P Y_{j}$, in which $\frac{\Delta Y_{i}}{\Delta X_{i}}=$ the marginal product of

$\mathrm{X}_{\mathrm{i}}$, and PY the price of the final product (KEHRBERG and REISCH 1969, p. 61). 


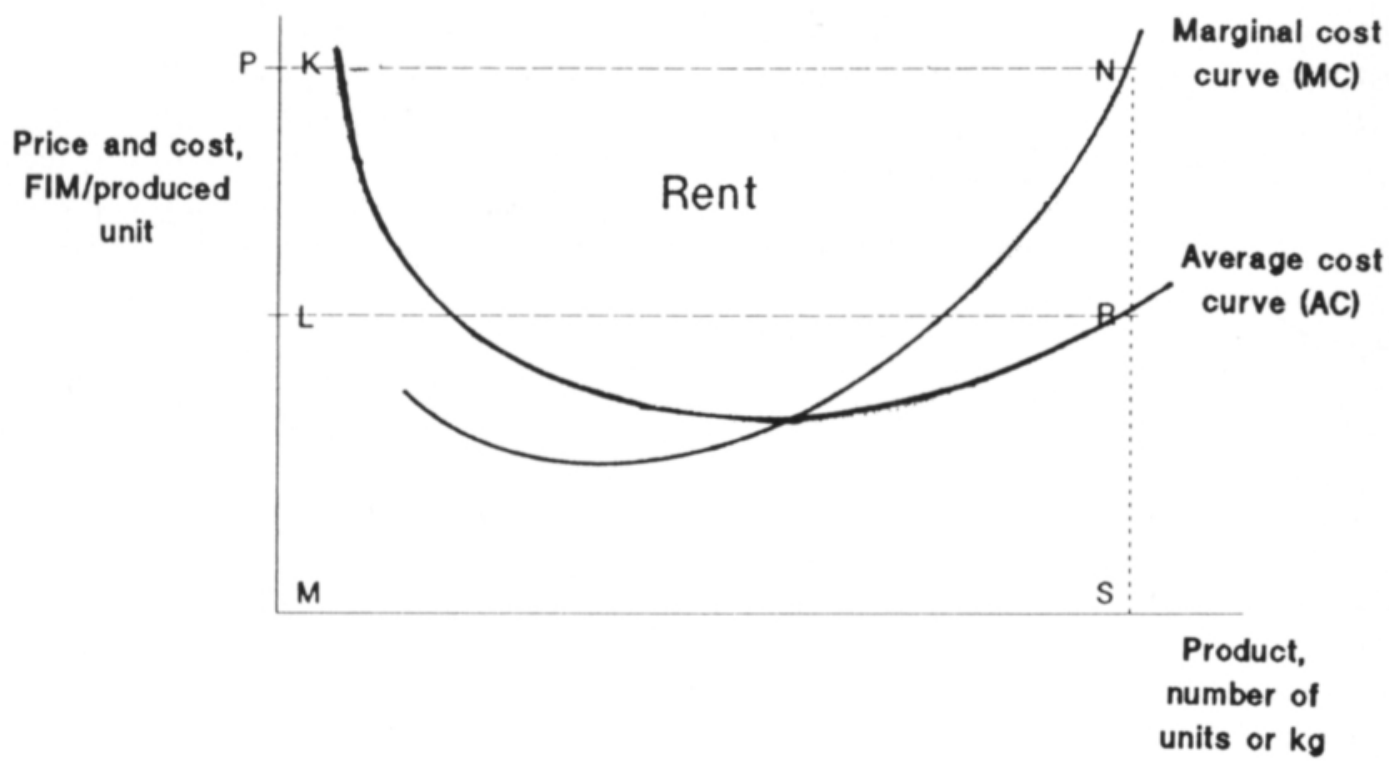

Figure 7. The determination of the economic rent by the marginal productivity approach (BARLOWE 1958).

duction factors, except land, are subtracted from this operating margin, we can obtain the return from land. The difficulty is how to determine the demand for compensation of other production factors (BARLOWE 1958, p. $164)^{2}$.

The theory of marginal productivity has generally been used to determine the demand for land for different purposes (GABR 1972, p. 14-17). The presuppositions for the use of the theory of marginal productivity are the validity of the law of diminishing productivity and the divisibility of production factors, which is not always possible to realize in agriculture (GRIESBACH 1966, p. 71-72).

A marginal productivity approach based on marginal value product has been used in several studies in the United States. The main objective of Strobenn's (1966, p. 11) study was an examination of the relation between the market value of land at the moment of investigation and its estimated value based on return. The data were collected from farms

\footnotetext{
${ }^{2}$ In the method described above, return from land has been assessed as a residual. The same method also applies to other production factors, as explained previously.
}

specializing in crop cultivation and beef, pork, and milk production. The marginal value product of different groups was estimated by using production function analysis. The results (p. 21) indicated that marginal value product of land on pig and beef farms decreased by c. $3 \%$ during $1949-1959$ and on dairy farms by c. $1 \%$ from 1954 to 1959 . The sharpest decrease was observed on grain farms, in which the marginal value product of land decreased from $12 \%$ to $4 \%$ during the investigated period. The decrease of the marginal value product of land on all farms indicated that land market value increased faster than the value of the other input groups. Schun and Scharlach (1966, p. 6-7) also demonstrated that the phenomenon of economics of scale could result in higher land values, as long as not all farms are able to acquire more land. Technological change can lead to intensification of production and enlargement of farm size which results in a rise of land value compared with other means of production.

LOCKEN et al. (1978, p. 50-63) used an approach based on marginal productivity when they estimated the use values of agricultural 
land in the State of New York. The production function of the basic model was exponential:

$$
\begin{aligned}
\mathrm{Y}=\mathrm{X}_{1}^{\mathrm{B}_{1}} \mathrm{X}_{2}^{\mathrm{B}_{2}} \ldots \mathrm{X}_{7}^{\mathrm{B}_{7}} \mathrm{U} \text {, in which } \\
\mathrm{Y}=\text { dependent variable, agricultural } \\
\text { production, } \\
\mathrm{X}_{1}-\mathrm{X}_{7}=\text { production inputs, } \\
\mathrm{B}_{1}-\mathrm{B}_{7}=\text { coefficients of regression, and } \\
\mathrm{U}=\text { error term. }
\end{aligned}
$$

The present value of land was assessed by capitalizing the marginal value product. For the consideration of quality factors, arable land was divided into three quality classes and the basic model was completed with dummy variables. The suitability of different models was tested on the basis of empirical data from 26 farms. The values of agricultural land determined in the study proved to be lower than the market prices paid.

Similar studies on land use have been made in the Nordic countries, e.g. HJELm 1963, Petrini 1964, PihKala 1965 and 1975, and ElSTRAND 1980. Moreover, by using the production function approach, several Finnish studies have examined the profitability of the acquisition of supplementary arable land. (e.g. Torvela 1966, Ylätalo 1978, Heinonen 1980, JuVONEN 1983).

Pihkala (1975, p. 291-306) addressed the applicability of methods describing the profitability of land use when studying the profitability of clearing forest land for arable land. Because the profitability of land clearing varied from farm to farm, marginal assessments were used to show the profitability of the additional agricultural land. The effect of an increase of one unit of invested capital and labour was also examined. In the study, a linear function and its logarithmic version were employed. The calculations showed that the extension of arable land on existing farms, within given limits, is more profitable than establishing new small farms by clearance activities.

The marginal value product of additional land can also be assessed by using linear programming. The main principles of this approach and its suitability for agricultural planning have been addressed in several Finnish studies (e.g. Weckman 1970, Pihkala and Lasola 1973, PihKala 1975). With regard to an individual farm, linear programming provides information on the effect of the extension or reduction of different production lines on marginal value product. Studies based on linear programming which deal with the marginal productivity of land have been discussed by, e.g. Clark (1973, p. 40-57).

The determination of the value of additional land by marginal analysis is relatively simple when there is unused production capacity on the farm and a few hectares of additional land have been acquired. This is probably the case in most small farms practicing traditional arable and/or livestock farming. On the other hand, if a large area of additional land has been acquired, so that the capacity of the existing production factors is no longer adequate, new investments will be required. Then, the determination of the costs generated by investments may be difficult.

\subsection{Studies based on market value}

\subsubsection{A general survey of price investigations concerning agricultural land}

Among the appraisal methods based on exchange, the most typical examines prices paid for properties on the free market. This approach is often applied to appraisals of individual property lots, such as arable lands, but is also used in the appraisals of farms as a whole. According to WiIAla (1976, p. 4), market value signifies the value of a certain real estate that has been defined according to the current price of similar real estates. It reflects the price of the lot on the free market at the moment of appraisal. By its nature, it is an objective value representing the current value deriving from the law of supply and demand (WIIALA 1966, p. 10).

An appraisal based on market prices has some important preconditions, such as, a 
sufficient quantity of practicable objects of transaction (compare MÄKI 1945, p. 47). Also, the largest possible sample of market prices of farms near the assessed land, comparable to it in quality, location, and size, must be examined. Thus, the appraisal has to be made according to the price majority or the mean value. GuSTAFSSON et al. (1978, p. 5253) summarized the conditions to be considered when applying the market price method to the determination of the value of agricultural real estates.

There is insufficient information in Finland on the prices paid for agricultural land. There are no regular statistical series or indices to indicate changes in the value of agricultural land. Yet, market price studies have been made concerning urban land in Finland (VIRTANen 1967, Myhrberg 1969, Kanerva 1974 and 1978 etc.). Moreover, many towns keep statistics on real estate transactions in their region. On the other hand, before the $\mathrm{Na}$ tional Board of Land Surveying started the registration of market prices of real estates in 1981 , price information covering the whole territory or concerning agricultural real estates was available only for brief periods. In addition, there may be reservations concerning former market prices, for reasons to be discussed later.

Information concerning the value and price covering the whole country is available from bookkeeping farms belonging to the official agricultural profitability survey. The value of arable land in bookkeeping farms is estimated according to the local price level. The bookkeeping advisor of the local agricultural advisory center determines, with the agricultural advisor and the farmer, the land price. One of the inadequacies of land value used in bookkeeping is that it is rarely revised (compare TORVEla 1966, p. 58, Ihamuotila 1968, p. 86). Nevertheless, the bookkeeping values of the 1950's are probably sufficient to describe the price level of land during that period. When Ihamuotila and Stanton (1970) tried to determine the quantity of capital invested in agriculture in the 1960 's, their point of departure was the value of agricultural land in 1951, based on the bookkeeping farms.

Many of the transactions concerning all or parts of agricultural real estates are such that their prices are not comparable. This was also the case when results were compared in price investigations of LEPONIEMI and LAMMI (1968), which covered the whole country in 1961,1962 , and 1966, as well as in other investigations on land price. Leponiemi and Lammi (ibid) examined farms as whole entities, complete with their buildings and forests, while most other land price investigations only examined the price of arable land. Moreover, the qualitative differences in arable land area may vary considerably (LEPONIEMI and LINDBERG 1966, p. 141).

When the market price of a whole agricultural real estate is known, the price of an individual lot can be determined by subtracting from the total value of the transaction the appropriate values of other properties. According to MĂKI (1964, p. 105), this procedure is followed when the share of the appraised lot is considerable with respect to the total price of the transaction. Thus the price of arable land can be appraised separately from the prices of farms that the state has purchased in voluntary transactions. The purchased farms have mostly been used as supplementary arable land for farms having development potential.

In the Department of Agricultural Economics of the University of Helsinki, academic theses have examined arable land prices using these data. The results of these studies have been compiled by RYYNÄNEN (1978 a, p. 78) who has also developed a time series describing the development of arable land prices (figure 8 ).

Though the information on arable land prices presented in figure 8 is somewhat inadequate, it provides a general picture of the development of land prices. Since the beginning of the 1960's, increase in arable land prices in southern and central Finland has been very rapid. Consequently, the real price of arable land doubled in these regions dur- 


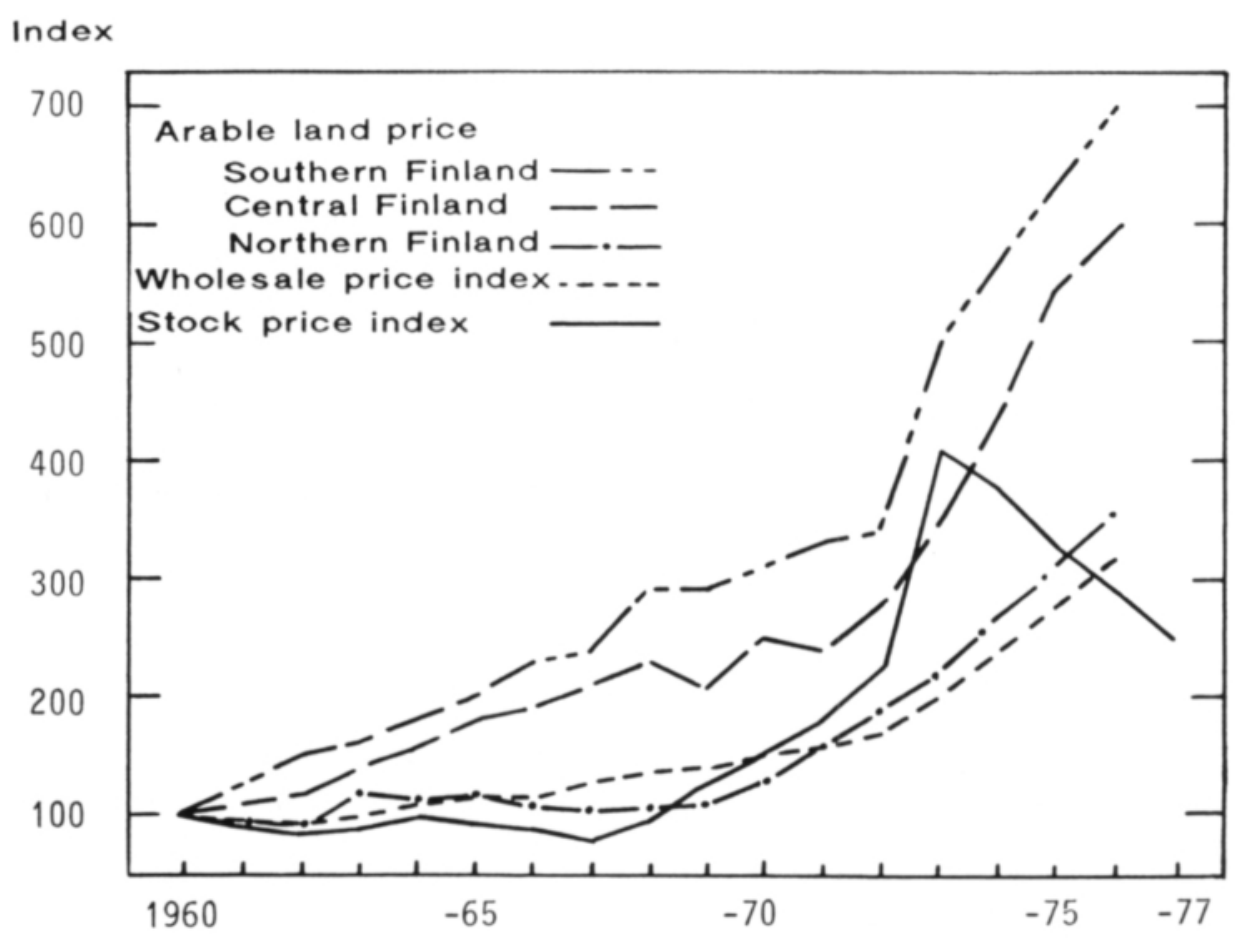

Figure 8. The relative price of arable land in southern, central and northern Finland, and the stock price and wholesale price index for the period 1960-1976.

ing the period 1960-1976. At the same time, the real price of arable land in northern Finland remained almost unchanged.

A parallel price development has been presented by VALKAMA (1979, p. 9-21), who examined the prices paid between 1960 and 1977 by the National Board of Agriculture for arable land in purchases financed within the framework of the Farm Act. According to this investigation, the real price increase of arable land, deflated by the wholesale index, was relatively greater in southern Finland during the 1960's, than during the 1970's.

On the other hand, according to the approach adopted by IHAMUOTILA and Stanton (1970), see also IнамuотіLA (1983, p. 16), in an investigation concerning capital stock in agriculture, the estimated land price also increased sharply at the end of the 1970's (table 5). In this investigation, the change in the price of agricultural land is one and a half times greater than the change in the producer price index for agricultural products, in percentage points.

Table 5. Price of agricultural land (FIM/ha) according to different statistical sources during 19771980.

\begin{tabular}{lccc}
\hline Year & $\begin{array}{c}\text { IHamuotila } \\
\text { (1983) }\end{array}$ & $\begin{array}{c}\text { Purchases of } \\
\text { the National } \\
\text { Board of } \\
\text { Agriculture } \\
\text { (NBA) }\end{array}$ & $\begin{array}{c}\text { Bookkeeping } \\
\text { farms, } \\
\text { weighted } \\
\text { average }\end{array}$ \\
\hline 1977 & 6566 & 5100 & 6681 \\
1978 & 7118 & 6022 & 7245 \\
1979 & 7758 & 6837 & 7619 \\
1980 & 9163 & 6662 & 8278 \\
\hline
\end{tabular}

IHAMUOTILA (1983, p. 18) points out that some reservations must be made concerning figures describing the price level of agricultural land presented in table 5 , because of inadequacies in statistics and price series. The 
figures reflect mean values for the whole country. Regional price changes may be considerable, as can be observed in figure 8 .

In a preliminary study for the National Board of Land Surveying concerning the province of Mikkeli, HeISKANEN (1977) investigated how market price statistics concerning scattered settlements could be determined and how they could be used to estimate the value of agricultural and forestry real estates composed of various types of lots. Some 818 transactions were studied, of which lots of supplementary arable land formed a relatively small proportion of the area for sale. According to HeisKanen (1977, p. 34), the information concerning the quantity and quality of real estate lots under agricultural and forest management proved inadequate for the determination of the price formation of agricultural and forestry land.

The newest studies in Finland addressing price and its impact on the development of arable land are investigations by HOLMSTEN and MyHrberg (1986), and Myhrberg and VÃĂNĂNEN (1988). The first study examined, through the use of price models, how different factors affect the price of arable land. The second study developed a special land-price index to show the price development of arable land in Finland, as a whole, and in different regions. Both studies used information from the market price register collected by the $\mathrm{Na}$ tional Board of Land Surveying. As a result of the studies, it is now possible to update an- nually the price index and publish it in the market price register.

\subsubsection{Price investigations concerning supplementary arable land}

The considerable development of arable land prices has been partly influenced by the change in the nature of real estate transactions since the beginning of the 1960's (RYYNÄNEN 1978 , p. 77-78). Earlier, a typical farm transaction was followed by the purchaser moving to the property and continuing cultivation. The farm on sale was an independent economic entity, managed as such by the purchaser. Today, transactions of agricultural real estates increasingly concern the purchase of supplementary arable land. Purchases of entire farms, to be cultivated as independent economic units, are now insignificant. Supplementary arable land is acquired by purchasing farms in part or in their entirety, as well as by purchases of separate lots.

To give a general picture concerning the price of additional land, the results of academic studies made in the Department of Agricultural Economics of the University of Helsinki are represented in table 6 . The results indicate that the price of supplementary arable land was approximately $9900 \mathrm{FIM} / \mathrm{ha}$ in Kymenlaakso, in southeastern Finland, in 1975. This price was clearly higher than in the agricultural district of Seinäjoki in western Finland, where the price was $6500 \mathrm{FIM}$ in the same

Table 6. Price of supplementary arable land (FIM/ha) and its development in different regions ${ }^{\mathrm{a}}$.

\begin{tabular}{|c|c|c|c|c|c|c|c|c|c|}
\hline Year & $\begin{array}{l}\text { Varsinais- } \\
\text { Suomi }\end{array}$ & $\begin{array}{l}\text { Ind. } 1975 \\
\quad=100\end{array}$ & Seinăjoki & $\begin{array}{l}\text { Ind. } 1975 \\
=100\end{array}$ & $\begin{array}{c}\text { Kymen- } \\
\text { laakso }\end{array}$ & $\begin{array}{l}\text { Ind. } 1975 \\
=100\end{array}$ & Kainuu & $\begin{array}{l}\text { Ind. } 1975 \\
=100\end{array}$ & $\begin{array}{c}\text { Wholesale } \\
\text { price } \\
\text { index }\end{array}$ \\
\hline 1972 & & & & & & & 1910 & 65 & 60 \\
\hline 1973 & & & & & 6550 & 66 & 2150 & 73 & 71 \\
\hline 1974 & & & & & 7980 & 81 & 2475 & 84 & 88 \\
\hline 1975 & 9361 & 100 & 6546 & 100 & 9890 & 100 & 2935 & 100 & 100 \\
\hline 1976 & 11840 & 126 & 7262 & 111 & & & 3161 & 108 & 111 \\
\hline 1977 & 15384 & 164 & 9165 & 140 & & & & & 123 \\
\hline 1978 & 17310 & 185 & 11277 & 172 & & & & & 129 \\
\hline
\end{tabular}

Sources:

a Ala-Kantti 1981, p. 72, Hannila 1980, p. 36, Măkela 1977, p. 31, HeikKinen 1978, p.80. 
year. The difference occurred because the agricultural land in Seinäjoki was not of the best quality. On the other hand, in the area of Varsinais-Suomi (southwestern Finland), the price paid was similar to the level paid in Kymenlaakso, namely 9360 FIM. However, in the Kainuu district of northeastern Finland, the price of supplementary arable land was only $2900 \mathrm{FIM} / \mathrm{ha}$.

The results indicate that the price of supplementary arable land in southwestern Finland increased more rapidly than in the agricultural district of agriculture in Seinäjoki. In both regions, the price rise of supplementary arable land was $72 \%-85 \%$ in 1978 , compared to 1975 , while, at the same time, the wholesale price index rose roughly $30 \%$. Even though the studies examined here are local studies, their conclusions show that the price of supplementary arable land continued to grow rapidly even at the end of the 1970's.

Besides the price formation of agricultural and forestry land, KAnTOLA (1979) has also studied their price development in the area of some municipalities surrounding the City of Hämeenlinna. Information on market prices and the physical characteristics of the lots was collected from the card index of district registrars, and later completed with supplementary information. Regression analysis and the regula falsi method were used as research methods for the analysis of land prices (KANTOLA 1978, p. 4-13). The model used in the study, based on an exponential function, was as follows (KANTOLA 1979, p. 46-47):

$\mathrm{H}_{\mathrm{P}}=\mathrm{I}_{\mathrm{P}} \times 497.362 \times \mathrm{S}_{\mathrm{H}}{ }^{-0.30} \times \mathrm{A}^{-0.17} \times \mathrm{K}^{0.33} \times \mathrm{B}^{0.56}$, in which

$\mathrm{H}_{\mathrm{P}}=$ price of arable land, FIM/ha,

$I_{P}=$ factor of price development of arable land (determined from data),

$\mathrm{S}_{\mathrm{H}}=$ location factor, in relation to the central built up area (Hämeenlinna), km,

A = size factor, measured as arable land area, ha,

$\mathrm{K}$ = centrality factor,

B = fertility factor, measured as tax classification points.
The empirical data concerning arable land consisted of all land transactions in the municipalities of Hattula, Renko, and Kalvola. The degree of determination of the model was approximately $85 \%$, while the residual standard deviation was approximately $21 \%$. Referring to the model, Kantola (1979, p. 98) constructed a table for arable land estimation that showed the determination of the price of individual lots. The increase in the real price of arable land was approximately $3.5 \%$ a year during the investigation period. Other similar models of the price of arable land, as well as the estimation tables based on them, have been constructed by, e.g. MatiKainen (1980) and Kanerva (1980). However, because the sources concern the prices of farms as a whole, the results do not give a sufficiently accurate description of the price formation of supplementary arable land, and for this reason they will not be discussed further in this chapter.

According to GulbrandSEN and LindBECK (1969, p. 66), the development of land prices cannot be explained by prevailing circumstances in an average agricultural enterprise. They claim that it is probable that the high price level of land is considerably influenced by the demand for supplementary arable land by large farms. GulbrandSEN and LindBECK (p. 66) explained the rise of land prices with a simplified model in which the price of agricultural real estates was assumed to rise along with the price of agricultural products (productivity was assumed to be constant and the prices of production factors unchanged). Land prices estimated according to the model in question were compared to the real prices paid for agricultural real estates. During the research period 1952 - 1966, the prices of real estates increased by approximately $5 \%$ a year, while the rise of the consumer price index was over $3 \%$. The land price rise corresponded mainly to the price paid for supplementary arable land by large farms. However, one should be cautious when evaluating the accuracy of the results. Further, it should be emphasized that the demand for supplementary 
Table 7. Prices of arable land and their variation in different research regions.

\begin{tabular}{lrrrrr}
\hline Land Price & Handeln & Vechta & Biberach & Heilbronn & Total \\
\hline Number of transactions & 134 & 103 & 127 & 143 & 507 \\
Mean value, DM/ha & 8437 & 17867 & 19006 & 30798 & 19184 \\
Stand. dev., DM/ha & 3435 & 11800 & 14609 & 40768 & 24915 \\
\hline
\end{tabular}

arable land by large farms, together with the entrepreneurial income of small farms, determines land prices (compare JAGG 1945, p. $48)$.

In a West German investigation, NositSCHKA (1973) determined factors influencing price formation of agricultural land. Market prices of lots of land were collected in four areas, 507 samples were examined altogether, which accounted for $15 \%$ of the land transactions in the regions concerned. Market prices in different regions had a high degree of variation, as shown in table 7 (NositschKA 1973, p. 55).

NositschKa (1973) and Wentrup (1978) estimated the effect of a number of variables influencing the variation of land prices, although the effect of any single variable on land price proved mostly to be weak. The most reliable variables explaining variations in land price were (NositschKA 1973, p. 55103):

1) density of population

2) share of farms of $5-10$ ha of all farms

3) average size of arable land lots in the area

4) soil quality of arable land lots

5) land suitability for construction purposes.
Even if good market price statistics concerning only supplementary arable land purchases were available by region and time, it would nevertheless be impossible to employ them as such in the appraisal of supplementary arable land. According to RYYNÄNEN (1967, p. 42), market prices can serve only to determine an abstract mean value, around which individual cases are dispersed. RYYNÄNEN $(1967$, p. 42$)$ argues that each individual case has to be appraised separately by taking into consideration its deviations from the characteristics of the farm representing the mean value. In this way, the value of each unique lot can be estimated.

A purchaser cannot refer only to market prices when evaluating the advantages brought to his farm by the acquisition of supplementary arable land, even though he/she possesses much information concerning transactions of supplementary arable land. This is because influences exogenous to agriculture may be contained in the price information. The market price approach is nevertheless adequate as a means of completing and revising the capitalized value approach (LOCKEN et al. 1979, p. 409-410). 


\section{DETERMINATION OF THE CAPITALIZED VALUE OF} SUPPLEMENTARY ARABLE LAND

\subsection{The research region}

The natural conditions for agriculture differ so much throughout Finland that the determination of the value of supplementary arable land has been considered necessary only in the case of one specific region. The southern and southwestern parts of the country are presented as one region in the official agricultural profitability survey, and they form an integrated region with respect to agricultural practices in the country as a whole. Thus, the bookkeeping region of southern Finland has been chosen as the research region ' (figure 9).
In southern Finland crop farming represents an essential part of agricultural production. Climatic conditions enable the cultivation of demanding crops. The cultivation of bread grains and root crops is concentrated in this region. According to Ulvinen (1980, p. 28), $99 \%$ of all seed inspections of spring wheat, and $82 \%$ of barley and oats in 1979, were made in the research region. As well as climatic conditions, soil conditions also have a direct bearing on crop cultivation. Clay soils prevail in the arable farming districts of Uusimaa, Varsinais-Suomi and Häme. Soils of fine sand, coarse sand, silt, and mull also occur in the area. Peat lands are rare (KURKI 1982, p. 95-99) in the research area.

Table 8 presents a description of the quality and quantity of arable land in the research

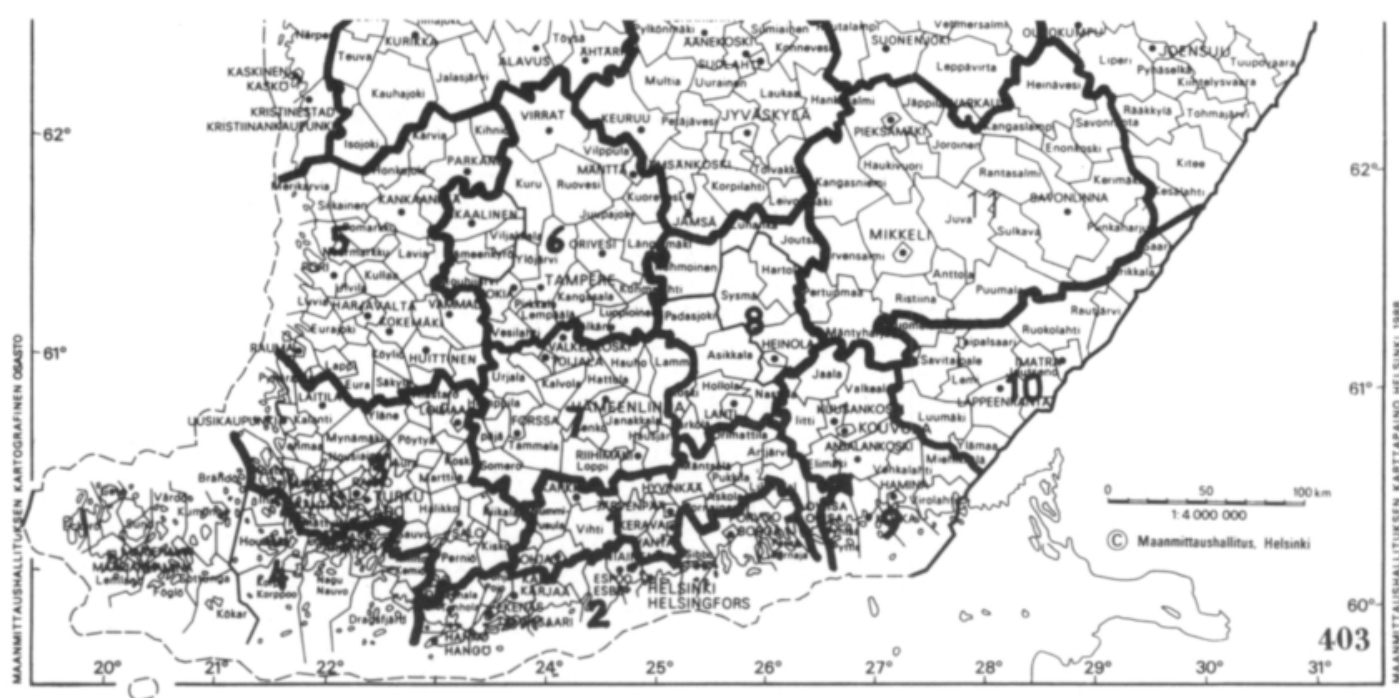

Figure 9. Research region.

1 The research region includes the following agricultural advisory centers and Swedish-speaking agricultural societies: Uusimaa (1), Nylands Svenska (2), VarsinaisSuomi (3), Finska Hushållningsällskapet (4), Satakunta
(5), Pirkanmaa (6), Province of Häme (7), Itä-Hăme (8), Kymenlaakso (9), and Etelä-Karjala (10). Kymenlaakso and Etelä-Karjala, until the end of 1985, constituted the agricultural center of the Province of Kymi. 
Table 8. Parameters describing arable land in the research region.

\begin{tabular}{lccccc}
\hline $\begin{array}{l}\text { Agricultural } \\
\text { advisory } \\
\text { center }\end{array}$ & $\begin{array}{c}\text { Class IA } \\
\text { of arable } \\
\text { land, \% }\end{array}$ & $\begin{array}{c}\text { Subsurface } \\
\text { drainage } \\
\%\end{array}$ & $\begin{array}{c}\text { Ave. arable } \\
\text { area } \\
\text { hac }^{\mathrm{c}}\end{array}$ & $\begin{array}{c}\text { Arable land } \\
\text { area ha } \\
\text { in the region }\end{array}$ & $\begin{array}{c}\text { Arable land } \\
\text { of the region } \\
\%\end{array}$ \\
\hline Uusimaa & 78.3 & 54.6 & 17.5 & 135315 & 37.0 \\
Nylands Svenska & 69.4 & 51.0 & 17.9 & 75142 & 33.2 \\
Varsinais-Suomi & 80.0 & 64.0 & 16.1 & 240371 & 40.5 \\
Finska Hushállninss. & 54.4 & 43.9 & 11.5 & 29226 & 17.7 \\
Satakunta & 51.5 & 48.0 & 10.8 & 178809 & 26.0 \\
Pirkanmaa & 37.9 & 26.9 & 10.2 & 109104 & 22.2 \\
Hăme & 80.0 & 57.5 & 15.9 & 155146 & 35.1 \\
Ită-Hăme & 62.0 & 40.8 & 11.8 & 68007 & 20.9 \\
Kymi & 53.5 & 30.7 & 11.4 & 152272 & 24.1 \\
Research region & & & & 114166 & 29.6 \\
as a whole & 65.3 & 48.7 & 13.4 & & \\
\hline
\end{tabular}

Notes:

a Anon. 1980 a

b ANON. 1980 b

c ANON. 1983 c. Figures are related to the arable land under cultivation.

region. The best arable land is found in the agricultural advisory centers of Uusimaa, Varsinais-Suomi, and Häme. The arable land of the eastern regions of northern Häme, northern Satakunta, and Kymi is of poorer quality, as demonstrated by the results of the arable land inventory study. On the whole, the quality of arable land in the research region can be considered to be clearly better than in the other bookkeeping regions. This is naturally reflected by the crop yield (information to be presented later). Moreover, technological innovations in agriculture are assumed to have been more rapidly accepted in the research region than elsewhere in Finland.

\subsection{Agricultural conditions during the research period}

The research period covers the years 1972 to 1986. Because southern Finland can be considered rather homogenous with respect to its soil conditions, climatic conditions are important, especially concerning the impact of weather on crop yields and their yearly variations. The years 1977-1979, as well as 1981, were poor because of high rainfall, while 1982 was warmer than normal. The years 1974 and 1976 were more favourable than the average weather conditions during the 1970's.
The feed unit is used for the description of crop yields, but its application to pasture and straw yields in the profitability survey are not taken into consideration. The tops of root crops are considered only when they are harvested. The average feed unit yield per hectare and the milk production per cow in the bookkeeping region of southern Finland are presented in table 9.

Table 9. Average feed unit yield per hectare and the milk production per cow from 1972 to 1986.

\begin{tabular}{lcc}
\hline Year & Feed unit/ha & $\begin{array}{c}\text { Milk production, } \\
\text { kg/cow }\end{array}$ \\
\hline 1972 & 3699 & 5028 \\
1973 & 3167 & 4944 \\
1974 & 3631 & 5027 \\
1975 & 3033 & 5096 \\
1976 & 3262 & 5508 \\
1977 & 2662 & 5575 \\
1978 & 2765 & 5600 \\
1979 & 2811 & 5716 \\
1980 & 3122 & 5934 \\
1981 & 2384 & 5738 \\
1982 & 3231 & 5869 \\
1983 & 3406 & 5934 \\
1984 & 3180 & 5948 \\
1985 & 3041 & 5943 \\
1986 & 3285 & 6249 \\
\hline Average for & & \\
years 1972-1986 & 3112 & 5607 \\
\hline
\end{tabular}

Source:

a Current Topics in Agricultural Economics. Results of bookkeping farms, business years 1972-1986. 
The effects of weather conditions appear, above all, as yield variations. Unfavourable weather conditions resulted in a sharp decrease in yield levels during 1977-1979. Except in 1985, yield levels have been higher during the 1980's, than the average yield level for the period 1972-1986 as a whole. Milk production per cow has mostly increased during the investigated period. There was a sharp increase in milk production during the middle of the 1970's. Besides the quality and quantity of feed crop, improvements in cattle breeding and the feeding of cows have also had an impact in the increase of the average milk production per cow. On the other hand, dairying is a long term economic activity, and so production level can be assumed to depend on a wide range of factors, not just those related to feeding and breeding.

Besides yields, the development of production costs, as well as price developments of agricultural products, have an impact on the farm economy. Some central indicators are presented in table 10 .

The economic conditions prevailing during the research period changed considerably.
This was especially the case with respect to the labour cost index, which is based on yearly wage statistics of average hourly wages of agricultural workers, which rose more sharply than the other factors. Even if the labour input in agriculture decreased during the research period, the simultaneous rise in labour costs contributed to labour being the second largest individual cost item, after the cost of purchased supplies (ANON. 1986 b). Thus, the greater increase in the price of supplies and labour, compared to producer prices and the cost-of-living index, had an effect on the profitability of agricultural production. On the other hand, producer prices and the costof-living index have evolved nearly in the same way.

\subsection{Choice and extent of data}

Data have been collected from farms that had continuously taken part in the agricultural profitability survey since 1968; 186 farms were studied in 1985. Cattle I and II farms, as well as farms practicing pig husbandry or grain cultivation, were chosen as research material in

Table 10. Indexes of producer prices and costs in agriculture during 1972-1986 $(1972=100)$.

\begin{tabular}{|c|c|c|c|c|c|}
\hline \multirow[t]{2}{*}{ Year } & \multirow{2}{*}{$\begin{array}{c}\text { Producer } \\
\text { price index }\end{array}$} & \multirow{2}{*}{$\begin{array}{c}\text { Price index } \\
\text { of agri. } \\
\text { supplies }^{\mathrm{a}}\end{array}$} & \multicolumn{2}{|c|}{ Labour $\cos \mathrm{t}^{\mathrm{b}}$} & \multirow{2}{*}{$\begin{array}{l}\text { Cost-of- } \\
\text { living } \\
\text { index }\end{array}$} \\
\hline & & & Men & Women & \\
\hline 1972 & 100 & 100 & 100 & 100 & 100 \\
\hline 1973 & 113 & 114 & 125 & 136 & 112 \\
\hline 1974 & 131 & 144 & 151 & 158 & 131 \\
\hline 1975 & 164 & 175 & 200 & 206 & 154 \\
\hline 1976 & 186 & 210 & 251 & 251 & 177 \\
\hline 1977 & 199 & 249 & 312 & 311 & 199 \\
\hline 1978 & 211 & 255 & 335 & 311 & 214 \\
\hline 1979 & 224 & 263 & 349 & 347 & 230 \\
\hline 1980 & 251 & 296 & 386 & 393 & 256 \\
\hline 1981 & 282 & 358 & 433 & 438 & 287 \\
\hline 1982 & 322 & 394 & 458 & 472 & 314 \\
\hline 1983 & 343 & 430 & 488 & 514 & 341 \\
\hline 1984 & 365 & 469 & 535 & 565 & 364 \\
\hline 1985 & 390 & 495 & 558 & 593 & 386 \\
\hline 1986 & 396 & 468 & 581 & 621 & 400 \\
\hline
\end{tabular}

Sources:

a Indexes assessed by the Agricultural Economics Research Institute.

b Based on hourly wages in the determination of the value of its own labour by the farm family in the agricultural profitability survey.

c Index of the Central Statistical Office. 
1985 (see table 11 for more information). In addition, the material included four farms that were classified as other crop cultivation farms, although they were considered to be grain farms in 1968. Thus, 155 farms remained in the investigation.

When the 1986 data were later collected, three farms were observed to have left the profitability survey. Because of the need to preserve the time series nature of the data, these three farms were also excluded from previous years. The final research data therefore consisted of 152 farms whose participation in the profitability survey had been uninterrupted throughout the research period, 1968-1986. The information relating to particular farms was collected both manually and from tapes in the Agricultural Economics Research Institute. The information consists principally of return, cost, and property value statistics.

When classifying farms by functions, they were first divided into two main groups, or farming systems: animal husbandry farms and grain cultivation farms; according to whether the return from livestock husbandry or from arable farming was greater in the gross return. The subdivision between these two types of farming was accomplished by examining the proportion of the main product in the gross return. The division into production lines, put into effect in 1983 in bookkeeping farms, is described by table 11 .

Table 11. Types of farm production lines.

\begin{tabular}{ll}
\hline Production line & Proportion of gross return \\
\hline Cattle farms I & $\begin{array}{l}\text { share of cattle production } \geq 80 \% \\
\text { (of milk }>50 \%)\end{array}$ \\
Cattle farms II & $\begin{array}{l}\text { share of cattle production } 60- \\
80 \%\end{array}$ \\
Pig farms & share of pig production $>50 \%$ \\
$\begin{array}{l}\text { Other livestock } \\
\text { farms }\end{array}$ & \\
Grain farms & $\begin{array}{l}>50 \% \\
\text { Share of bread and feed grain }\end{array}$ \\
Other crop culti- \\
vation farms
\end{tabular}

This division into production lines has been under revision since 1968, although the changes have been relatively slight. These changes have been explained in detail in "Current Topics in Agricultural Economics”, published by the Agricultural Economics Research Institute. It is worth noting that before 1983, the bread grain return on grain farms had to be over $30 \%$ of the gross return in order to be classified as grain farms. Since 1983, the gross return from bread and feed grains on grain farms has to be over $50 \%$.

There have been small changes in the farms from one production line to another during the research period. The changes are partially explained by variations in gross returns on farms, i.e. the basis of the division into production lines. Some of the changes in the farms' functional classifications stem from changes in their production structure and in their specialization. LATUKKA (1989) has examined the stability of farm structure in detail.

Because the bookkeeping data is principally designed to determine the capitalized value of supplementary arable land, only farms strongly oriented towards utilization of arable land under cultivation will be considered.

Cattle farms include farms on which the gross return from cattle represents at least $80 \%$, and the gross return from milk production at least $50 \%$ of the gross return from agriculture. In these farms livestock husbandry rests basically upon feed produced on the farm and not on an abundant use of purchased feed, as in the case of pig farms, for example. Cattle I farms will simply be called cattle farms in subsequent text.

Grain farms are the best representation of the dependence of production activities on crops, because the returns from grain sales represent the major part of the gross return from agriculture.

Table 12 indicates the development in the number of farms chosen for investigation when the division into production lines has been made according to calculations from the annual bookkeeping. 
Table 12. Development of the number of investigated farms, 1968-1986.

\begin{tabular}{lcc}
\hline Year & Cattle farms & Grain farms \\
\hline 1968 & 14 & 36 \\
1969 & 22 & 32 \\
1970 & 22 & 26 \\
1971 & 29 & 23 \\
1972 & 39 & 21 \\
1973 & 45 & 16 \\
1974 & 40 & 24 \\
1975 & 43 & 44 \\
1976 & 44 & 50 \\
1977 & 57 & 41 \\
1978 & 60 & 42 \\
1979 & 52 & 41 \\
1980 & 51 & 44 \\
1981 & 54 & 49 \\
1982 & 44 & 51 \\
1983 & 44 & 54 \\
1984 & 42 & 58 \\
1985 & 43 & 58 \\
1986 & 41 & 50 \\
\hline
\end{tabular}

The figures show that the number of farms in each class are rather small. Consequently, the final material only includes data since 1972. At the end of the research period the number of cattle farms increased to over 40 and that of grain farms to 50. For statistical analysis the number of farms is sufficient because the data in question are "panel data", where time series of farm data are employed.

The size of a farm has been traditionally measured by its arable land, but this is not the sole indicator of the size of a farm, because even large farms can be managed without arable land. This is why turnover and labour input have also been used to measure the size of a farm. Nevertheless, arable land is an inseparable part of agriculture and its superiority in measuring the size of the farm can be based on the increasing use of factors of production following the extension of arable area.

Economic results with respect to the arable area of farm were declared in the profitability survey as converted arable hectare until 1975. Since 1976, results have been fixed according to the total area of arable land in use, as well as the leased arable area. In this study, the arable area is defined in a different way than in the profitability study. Arable area
Table 13. Development of arable land area (ha/farm) during 1972-1986.

\begin{tabular}{lcc}
\hline Year & Cattle farms & Grain farms \\
\hline 1972 & 19.47 & 37.56 \\
1973 & 20.27 & 44.53 \\
1974 & 19.89 & 45.39 \\
1975 & 21.52 & 44.05 \\
1976 & 21.03 & 40.07 \\
1977 & 22.79 & 41.53 \\
1978 & 24.30 & 37.93 \\
1979 & 23.03 & 39.04 \\
1980 & 23.92 & 36.15 \\
1981 & 25.47 & 37.41 \\
1982 & 25.05 & 37.00 \\
1983 & 24.68 & 36.26 \\
1984 & 26.07 & 37.10 \\
1985 & 26.28 & 37.00 \\
1986 & 27.85 & 39.45 \\
\hline Average & 23.44 & 39.36 \\
\hline
\end{tabular}

(table 13) is considered to be the arable land area under cultivation and the fallow area was excluded in such cases where fallow agreements are in force.

The arable land area of cattle farms has increased from approximately 20 hectares to almost 28 hectares while the variation of the arable land area on grain farms has been clearly less. On the other hand, grain farms are generally almost twice as large as cattle farms. By the end of the research period the size differences between the farm types were decreasing.

\subsubsection{Private economic reasons for acquiring supplementary arable land}

The main objective of the professional farmer is to secure the best possible return from labour performed by himself and his family, as well as to obtain a sufficient interest on capital invested in the farm enterprise (compare MĂKı 1964, p. 69). For the realization of these objectives, the farmer has to adapt his production activities from time to time to respond to changing circumstances. Then, in theory, he may continue with the production structure unchanged, but more likely, he will attempt to modify it to meet the new circumstances. The modifications to the production structure can be made by reducing 
the use of factors of production. The agricultural policy measures prevailing in the second half of the 1970's, aimed at a reduction in production volumes based on voluntary schemes, in which farmers were eligible for state grants to reduce the use of factors of production. Despite these efforts, individual farmers have strived to increase their production and returns. In practice, this latter effort has manifested itself as an increase in the volume of use of production inputs, the implementation of new technology, or as efforts to increase the arable land area of the farm.

The increase in production at the farm level can be economically justified to the point where the marginal value product and the marginal cost of different factors of production are equal. At this point, the optimum size of the enterprise in the short term is attained (RENBORG and KARLSSON 1969, p. 15). If production activities occur in the area of diminishing productivity ${ }^{2}$, the optimum is obtained when:

$\frac{M V P_{x_{1}}}{P_{x_{1}}}=\frac{M V P_{x_{2}}}{P_{x_{2}}}=\frac{M V P_{x_{3}}}{P_{x_{3}}}=\ldots \frac{M V P_{x_{n}}}{P_{x_{n}}}=1$.

In the formula, $\mathrm{MVP}_{\mathrm{x}_{\mathrm{i}}}$ signifies the marginal value product of each input $\left(\mathrm{x}_{1} \ldots \mathrm{x}_{\mathrm{n}}\right)$ and $\mathrm{P}_{\mathrm{x}_{\mathrm{i}}}$ the marginal cost of the use of the input $\mathrm{x}_{i}$. Sometimes, inadequate resources (K) can set a limit to the expansion of production to such an extent that the above-mentioned formula is not valid. In this case, the optimum result is attained when the marginal value products are equal, or

$$
\begin{aligned}
& \mathrm{MVP}_{1}=\mathrm{MVP}_{2}=\ldots \mathrm{MVP}_{\mathrm{n}} \text {, when } \\
& \mathrm{x}_{1}+\mathrm{x}_{2}+\ldots \leq \mathrm{K} .
\end{aligned}
$$

In practice, the harmonious use of means of production in farms has proved to be dif-

\footnotetext{
2 According to the law of diminishing returns "adding more units of one of the factors generally causes an increase in total output, but there will be reached a point beyond which continued adding of units will cause a lessthan proportional increase in output". (Source: Economics Dictionary)
}

ficult to organize, although studies by, e.g. RENBORG and KARLSSON (1969), RouHIAINEN (1972), TURKKI (1982) show rather the contrary. In regions where small farms predominate, there is often overcapacity with respect to labour and equipment (e.g. TwEETEN 1969, JOHNSTON and BISCHOFF 1971, RYYNÄNEN 1978). Consequently, some of the productive capacity is underused, which reduces profitability in agriculture. According to PenRose (1959, p. 67-68), factors of production used below full capacity represent an important internal incentive for the growth of the enterprise. Thus, by acquiring supplementary arable land, the farmer is able to increase his returns from other factors of production. The average cultivation costs per hectare decrease as a result. The greater the present use of a factor of production is out of its maximum capacity, the greater the decrease in the fixed costs when the production is expanded. Consequently, an extension of the arable land area is not important as such, but it serves to improve the profitability of production.

On most farms labour, buildings, and equipment represent fixed factors of production, the use of which must be intensified because their opportunity cost outside agriculture remain low or absent, e.g. the labour input of the farmer. Farmers are rarely trained for jobs outside agriculture which require specialized skills, and they often lack information concerning alternative job opportunities outside the farm. Moreover, no part-time job may be available in the farm's immediate surroundings. To make matters worse, the time free of agricultural duties, especially on cattle farms, is distributed systematically in short periods around the year and, thus, sets constraints on the possibility to seek a part-time job.

PREUSCHEN (1968, p. 28) argues that the objective of a private farmer is often to extend the arable land area to the limits set by the available labour. At the same time, he cautions against increases in area that might result in a considerable increase in the burden of work for the farm family, oversized investments in equipment and/or a decreasing pro- 
ductivity of labour. In the most unfavourable case, all three negative factors can have a combined effect.

On the other hand, when acquiring supplementary arable land, new factors of production may be purchased in which the productive capacity may not be completely exploited. For example, it may be the acquisition of another tractor that results in the increase of fixed costs per product unit or per arable hectare (compare figure 10, curve b). In such a case, the acquisition of supplementary arable land is more unprofitable than for farms on which there is no need for the acquisition of additional factors of production (BARNARD and Nix 1973, p. 47).

The extension of the arable area of a farm is also profitable because, below full capacity, the use of a factor of production generally results in a lower cost per unit area or per product unit in a large farm compared to a small one, even if there remains an equal amount of unused capacity in both cases. In figure 10 , the segment of line $a b$ is longer than line cd, even though in points $x_{1}$ and $x_{2}$ similar equipment is acquired. The smaller rise of unit costs in point $\mathrm{x}_{2}$ results from the divider being greater than at point $x_{1}$. The costs of such factors of production that are not needed for the expansion of the farm decrease per production unit in a degressive way (figure 10, curve C).

In agricultural economics, considerable consideration has been given to the size of

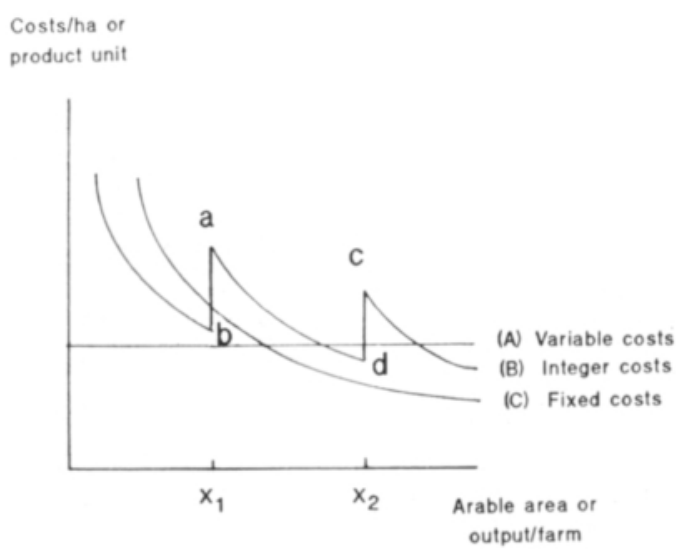

Figure 10. Impact of the size of enterprise on costs. farm that the farm family is capable of managing with the prevailing level of technology (e.g. JoHNSSON and BISCHOFF 1971, Torvela and Mä́I 1974, HeikKILÄ 1987). Arable land has usually been used for measuring the size of a farm, and yet, the description is not sufficiently unambiguous (e.g. Torvela 1980 , p. 104-106), because the arable area cannot express differences in cultivation intensity: extensive pasture cultivation and, its opposite, the intensive cultivation of roots and vegetables. In the latter case, the cultivation is based on a considerable use of labour and capital per unit area. Land is no longer so important as a factor of production as formerly, when the use of other means of production (purchased fertilizers and pesticides) was less intensive.

If only crop production is practiced, the arable land of the farm becomes significant. On the other hand, livestock production based on home grown feed also depends on arable farming and, thus, on the arable land area. Cattle farms are typical examples of farms in which the production of coarse feed (hay, silage, pasture, and straw) is closely connected with arable land area. On the other hand, livestock husbandry based on purchased feed does not really depend on the size of the farm. It is possible to use purchased feed only, particularly in pig and poultry farming. Consequently, the production structure of a farm, its cultivation intensity and available methods of production, as well as the know-how at the farmer's disposal, each have a decisive impact on the size of farm the farm family is capable of managing. Moreover, the size requirements of a farm change constantly, so the setting of exact limits is impossible.

RYYNÄNEN (1981) provides a general picture of the appropriate size of a farm in southern Finland:

Production specialization Arable land, ha

Grain farming $\quad 60$

Dairy farming 20

Pig farming 30

Egg farming 20. 
The relatively low labour input into crop farming, when it is the sole production line, often requires a larger arable area than in the case of livestock husbandry. On the other hand, many part-time farmers exclusively practice crop cultivation, often on rather small farms.

\subsubsection{Measuring the return from supplementary arable land}

When considering the acquisition of supplementary arable land, the costs and returns involved have to be estimated beforehand. In this way, the price paid for supplementary arable land is based on both capitalized value and market value. The future rise in value of the farm or the arable lot is often considered as the return on the acquisition.

Upon acquisition of supplementary arable land, the market value of a farm can increase considerably more than that indicated by the market price. Nevertheless, in this study, the examination of the capitalized value of additional land is considered only on the basis of the return derived from the supplementary arable land and not on the basis of the increment of market value probably produced by it.

The research data consist of bookkeeping farms that have been classified by the types of farm, and so the approach to the measurement of the return from supplementary arable land is based on the available information they provide. In the agricultural profitability survey, the economic results of bookkeeping farms are calculated annually, and the profitability in agriculture is presented in absolute monetary terms (FIM) or in ratios. Because the focus of this part of the study is the determination of the capitalized value of supplementary arable land, expressed in marks, attention will be given to the suitability of the concepts of economic results to the task in hand. From the point of view of the farmer, the effect of the acquisition of supplementary arable land on his wage and on the interest of the capital invested on the land purchased is of central importance.
When determining the return on supplementary arable land, the changes in the farm economy, consequent upon the land acquisition, must always be considered. The increase of the arable land area results in an increase in gross return, costs, and labour input. Therefore, it is necessary to consider the concepts of marginal value product, differential value product, and the corresponding concepts of cost.

As explained in section 3.1.3., the taxable net return, assessed as a residual, remained negative, especially in small farms. It is therefore unsuitable for the determination of the average value of agricultural land. Nevertheless, the growth of net return is usually positive, even though it would remain negative after the acquisition of supplementary arable land. Consequently, taxable net return is, in principle, an appropriate concept of operating margin for indicating the profitability of the acquisition of supplementary arable land by farms. On the other hand, small farms, specialized in livestock husbandry, aim to intensify the exploitation of labour and other factors of production by acquiring supplementary arable land. Then, the increment in returns resulting from the additional arable area can be examined with appropriate parameters. Such parameters are: the farm family income and the operating margin.

The indivisibility of factors of production impedes the measurement of the return from supplementary arable land: the exact area of land desired can rarely be acquired, the cultivated arable area cannot be freely distributed to different crops, and equipment and buildings rarely exactly correspond to the demands set by the cultivated area. The return on supplementary arable land and its development can be examined, in principle, following Brandes and Woermann (1969, p. 212), figure 11.

Figure 11 shows that the first result of a gradual extension of area is an increase in the marginal value product and average value product. The prerequisite for an efficient use of the means of production is a certain mini- 
$\mathrm{FIM} / \mathrm{ha}$

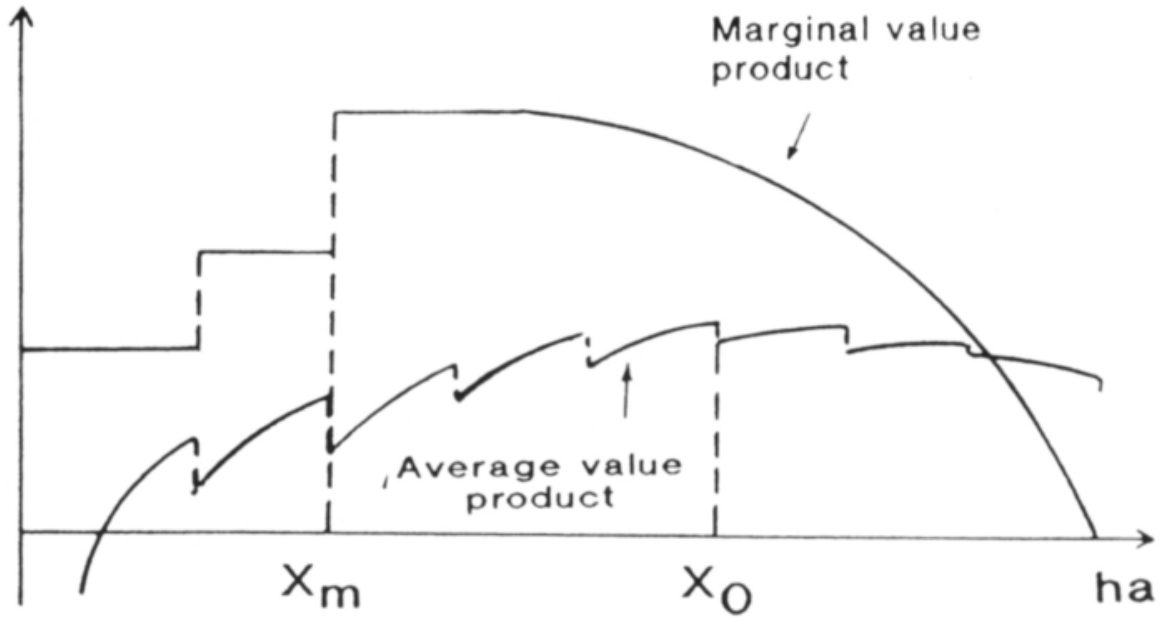

Figure 11. Effect of supplementary arable land on curves of marginal and average value product on an individual farm.

mum area so that the indivisible factors of production can be used in a most efficient way. When the area of the farm has increased to reach point $\mathrm{X}_{\mathrm{m}}$, it is large enough for the most efficient use of factors and means of production. When the optimum use of factors of production is reached and the enterprise still expanded, the marginal value product begins to decrease. If the area is increased further, transportation costs increase. This results in a decrease in the marginal value product. The average value product decreases only after the point $\mathrm{X}_{\mathrm{o}}$ when the optimal degree of use of the indivisible factors of production has been exceeded.

In this study, the acquisition of supplementary arable land is regarded as the farmer's goal to ensure for him and his family at least average preconditions for agricultural husbandry in the future. Under these circumstances, the acquisition of supplementary arable land cannot be regarded solely as an investment, but in several cases it can be related to the supply of additional work for the farm's permanent labour force.

To assess the return from supplementary arable land, an extensive measuring instru- ment was chosen, namely the concept of gross return of agriculture, which is outlined in section 4.4.2. The assessment of the return from supplementary arable land is based on the analysis of production functions explaining the gross returns from agriculture. Based on the average use of production inputs, the marginal productivity of different inputs can be determined, e.g. the marginal value product of the supplementary arable land can be estimated. In the examination of the dependence of the marginal value product of supplementary arable land on the size of farm, the taxable net return in agriculture, which indicates the interest on capital invested in agriculture, and the taxable part of the gross return from agriculture, are also used.

\subsection{Production function analysis}

\subsubsection{General grounds for the use of production functions}

The production function is a central concept in microeconomics. Several analyses concerning individual farms or agricultural production are based on the use of parameters es- 
timated from production functions, e.g. investigations dealing with the use, demand, and supply of production inputs. The applicability of production functions to agriculture has been examined in several studies in agricultural economics (e.g. Heady 1949, KetTUNEN 1966, and Heady and Dillon 1972).

The following general function serves to demonstrate the dependence of agricultural production on different factors:

$\mathrm{Y}=\mathrm{f}\left(\mathrm{X}_{1}, \mathrm{X}_{2} \ldots \mathrm{X}_{\mathrm{n}}\right)+\mathrm{u}$, in which

$\mathrm{Y}=$ output in agriculture and $\mathrm{X}_{1}, \mathrm{X}_{2} \ldots \mathrm{X}_{\mathrm{n}}$ are production inputs and $\mathrm{u}=$ an error term. The error term includes the effects of stochastic disturbances, such as, the weather and the natural fertility of the soil. Depending on the production structure and farm individuality the technological level can vary to a considerable extent. The level of mechanical technology appears partly as variation in the quantity of agricultural property. Technological differences between farms are probably also reflected in the size of the error term u, resulting from different annual use of, for example, equipment.

A central problem in the use of production function estimations is to find a common unit of measurement for the outputs and inputs. For this reason, different quantities of outputs are often expressed in monetary terms or as returns in economic analyses. In the same way, most production inputs are expressed in monetary terms. Outputs and inputs have then both a quantitative and a qualitative expression. The time and place of purchase and sale also have an impact on the amount of returns, as well as on the prices of inputs.

Because the data have been collected from the years 1972-1986, cross section and time series analyses are employed. Consequently, in the time series analysis fixed prices are used for the elimination of price changes. The simultaneous handling of several variables can be accomplished by regression analysis. However, in the selection of variables for the regression analysis, care must be taken to avoid multicollinearity which would impede the interpretation of the coefficients of regression. In addition, the possible correlation of variables in the model with exogenous factors must be noted.

Regression analysis was chosen in this study for the examination of main factors influencing returns in agriculture. By determining the marginal value product of production inputs, the profitability of the use of separate production inputs can also be examined. Arable land is considered first.

\subsubsection{Selection of variables}

Although the research data concern two types of farms, within each group conditions are relatively homogenous. Nevertheless, there are considerable differences between these two types of farms with respect to both structure and production. Intensive production of feed is typical on dairy farms, while on grain farms production is mainly based on cultivation of cash crops. Variations in yield appear very clearly in the economic results of grain farms (LATUKKA 1989, p. 41-44). On the other hand, cattle farms are not as sensitive to variations in the quality and quantity of yield as grain farms. For this reason, the special characteristics of the production structure of each type of farm are observed in the choice of variables.

The research problem often clearly determines the choice of variables. By using logical deduction, the choice of variables relevant to the economic result in agriculture can be made, at least partially. The selection of variables is difficult, because a number of variables cannot be used due to a lack of information about them. A significant variable of this type is land quality, which directly affects crop yields (compare RYYNÄNEN 1967, p. 51). The professional skills of farmers and technological change are also problematic variables.

It is possible to select variables on the basis of logical deduction, as well as on tests concerning the explanatory power of new varia- 
bles (Kettunen and Torvela 1969, p. 3450). Factor analysis can also be used as a source of preliminary information on the importance of different variables in the model.

Along with factor analysis, the selection of variables can be made by using selective regression analysis which can select from a number of variables, those with the greatest explanatory power with respect to the dependent variable. Then, the number of variables in the model depends on the required statistical significance of the coefficients.

The gross return from agriculture has been chosen as the dependent variable, Y. This broad indicator indicates the combined value of final products of agriculture during the business year. The gross return from agriculture of the profitability survey includes the following return items (ANON. 1986 b, p. 26):

1) Cash receipts and accounts receivable for the accounting year, excluding cash receipts obtained through liquidation of property on hand at the start of the year.

2) Cash value of deliveries in kind transferred from agriculture to forestry, food and private household, pensions, supplementary enterprises, and wages.

3) Increases in stocks and domestic animals derived from agricultural production. Stocks do not include stocks of root crops and coarse feed that have been produced on the farm and are destined to be used on the farm.

The gross return in agriculture also consists of state grants (e.g. support paid according to arable land area and compensation for crop failure) that are paid directly to farmers. On the other hand, the gross return does not include investment-like state grants and allowances (e.g. allowance for subsurface drainage). The gross return still includes the value of the housing privilege of the farm family and pensioners, as well as returns from the renting of dwellings.

The main criterium for the selection of variables explaining the gross return of agricul- ture was logical deduction concerning factors influencing agricultural production. In addition, theories of production and costs, as well as correlation analysis, were used to support the selection. The aim was to design the model with such explaining factors that have, in reality, a causal relationship with the dependent variable. Accordingly, the following variables were selected for investigation:

$\mathrm{Y}=$ dependent variable $=$ the gross return from agriculture, FIM/farm.

Independent variables:

$\mathrm{X}_{1}=$ arable land area, ha/farm

$\mathrm{X}_{2}=$ cost of purchased fertilizers, FIM/farm

$\mathrm{X}_{3}=$ cost of purchased feed, FIM/farm

$\mathrm{X}_{4}=$ cost of purchased seeds, FIM/farm

$\mathrm{X}_{5}=$ plant protection, grain drying, FIM/ farm

$\mathrm{X}_{6}=$ cost of equipment, FIM/farm

$\mathrm{X}_{7}=$ livestock costs, FIM/farm

$\mathrm{X}_{8}=$ imputed wage of the farmer and his family including management, FIM/ farm

$\mathrm{X}_{9}=$ labour cost, FIM/farm

$\mathrm{X}_{10}=$ cost of buildings, FIM/farm

$\mathrm{X}_{11}=$ investment cash expenses in equipment, $\mathrm{FIM} /$ farm

$\mathrm{X}_{12}=$ investment cash expenses in buildings, FIM/farm

$\mathrm{X}_{13}=$ agricultural works, FIM/farm (farm family + hired labour)

$\mathrm{X}_{14}=$ investment cash expenses in equipment and buildings, FIM/farm

$\mathrm{X}_{15}=$ other costs, FIM/farm.

The independent variables mainly describe cash expenses or costs. The names of variables are defined by their content. In this study, variables are determined in the same way as in the profitability survey. (For a more detailed description of their content see ANON. 1986 b). Only the determination of costs of equipment, buildings, and the depreciations of land improvements are different from the accounting practices followed by the profitability survey (see appendix 1), 


\subsubsection{The functional form of the production function}

In this investigation, the form of the production function is based partly on a priori hypotheses, partly on experiences from earlier studies of production functions in agriculture (e.g. Kettunen and Torvela 1969, Ryynänen 1970, RouHIAINEN 1972), and partly on experimentation. The degree of determination $\left(\mathrm{R}^{2}\right)$, as well as the statistical significance of coefficients of regression, are used to assess the suitability of the function. In addition, the theoretical appropriateness of the signs of the coefficients are considered.

Earlier production function studies on Finnish farms have applied linear and logarithmic functions (KetTunen and Torvela 1969, p. 53). In the present study, a linear function of the following form will be tried first:

$$
\begin{aligned}
& \mathrm{Y}=\mathrm{a}+\mathrm{b}_{1} \mathrm{X}_{1}+\mathrm{b}_{2} \mathrm{X}_{2}+\ldots \mathrm{b}_{\mathrm{n}} \mathrm{X}_{\mathrm{n}}+\mathrm{u} \text {, in which } \\
& \text { y = dependent variable, } \\
& \text { a = constant, } \\
& \mathrm{X}_{1} \ldots \mathrm{X}_{\mathrm{n}}=\text { independent variables, } \\
& b_{1} \ldots b_{n}=\text { coefficients of regression, and } \\
& \mathrm{u}=\text { error term. }
\end{aligned}
$$

In this function, the relation between input and output remains linear when the use of an input is increased. However, the law of diminishing returns is normally valid in agricultural production (MÄKI 1964, p. 271). Accordingly, when an input is increased, returns gradually reach a level where they increase in a degressive way and ultimately reach a maximum point. In most bookkeeping farms, agriculture is practiced usually in the region of degressive growth in returns. Under these circumstances, the linear function is no longer valid.

Logarithmic functions allow more flexible transformations. First, a traditional CobbDouglas function of the following form will be used:
$\mathrm{Q}=\mathrm{aX}_{1} \mathrm{~b}_{1} \mathrm{X}_{2}{ }^{\mathrm{b}_{2}} \ldots \mathrm{X}_{\mathrm{n}}^{\mathrm{b}_{\mathrm{n}}}$, in which

$$
\begin{array}{ll}
\mathrm{Q} & =\text { dependent variable, } \\
\mathrm{a} & =\text { constant, } \\
\mathrm{X}_{1} \ldots \mathrm{X}_{\mathrm{n}} & =\text { independent variables, } \\
\mathrm{b}_{1} \ldots \mathrm{b}_{\mathrm{n}} & =\text { regression coefficients, and } \\
\mathrm{u} & =\text { error term. }
\end{array}
$$

The function is readily applicable to the estimation and interpretation of the function. Parameters $b_{1} \ldots b_{n}$ are production elasticities. They indicate the percent rise of gross return when the use of inputs (variables) is increased by one percent. The sum of elasticities indicate the returns to scale of production. The sum of elasticities $\Sigma_{i} b_{i}$ may be $<1,=1$ or $>1$. The first case is governed by the law of diminishing returns, the second one by the law of constant returns and the third one by the law of increasing returns to scale (e.g. Nittamo 1969, p. 12, PekKarinen and Sutela 1979, p. 37-38).

For estimation, a Cobb-Douglas function can be expressed in the following form:

$\log Q=\log a+\Sigma_{i} b_{i} \log X_{i}(i=1,2,3 \ldots n)$.

The marginal value product will be determined from:

$$
M V P_{X_{i}}=b_{i} \frac{Q}{X_{i}} .
$$

As a second function, the following transcendental function will be tried:

$$
Q=a X_{1}^{b_{1}} e^{c_{1} X_{1}} X_{2}^{b_{2}} e^{c_{2} X_{2}} \ldots X_{n}^{b_{n}} e^{c_{n} X_{n}} .
$$

This function is, in fact, a combination of the linear function and the Cobb-Douglas function.

The merit of this function, compared with a Cobb-Douglas function, is its flexibility. It obtains very variable forms according to the values and signs of regression coefficients (e.g. Kettunen and Torvela 1969, p. 54). For estimation, the function obtains the following form:

$\log \mathrm{Q}=\log \mathrm{a}+\Sigma_{\mathrm{i}} \mathrm{b}_{\mathrm{i}} \log \mathrm{X}_{\mathrm{i}}+\Sigma_{\mathrm{i}} \mathrm{c}_{\mathrm{i}} \mathrm{X}_{\mathrm{i}}$

$$
(i=1,2,3 \ldots n) \text {. }
$$


The marginal value product

$M V P_{X_{i}}=\left(\frac{b_{i}}{X_{i}}+c_{i}\right) Q$.

\subsubsection{Results of the regression analysis}

The differences in the production structure of individual farms have a significant effect on the economic result in agriculture and, thus, on returns derived from supplementary arable land. The assessment of returns from supplementary arable land were therefore made separately for cattle and grain farms. An intensive pasture economy is typical in cattle farms, while grain farms mainly specialize in the cultivation of marketable crops. Consequently, the quantities and shares of different production inputs differ considerably according to the type of farm.

The main focus of the study is the determination of returns from supplementary arable land during the final years of the research period. The returns from supplementary arable land are to be determined most thoroughly for the period 1982-1986, for which price information from the market price register is also available.

Even though the research data concern farms that have continually practiced bookkeeping since 1972 , a cross section analysis is used for certain years before 1982. Estimations were eventually made for the following years: 1972, 1976, 1980, and 1982-1986. As to the yield, the years 1972 and 1976 represent at least the average level of the research period (see table 9). The same applies to the year 1980.

The extension of the cross section analysis back to the year 1972 enables the examination of the development of the capitalized value of arable land as a function of time, i.e. the need for supplementary arable land has most obviously increased during the research period along with the implementation of new laboursaving technologies.

Coefficients of the functions are estimated with regression analysis in which the validity of the models is considered primarily accord- ing to the degree of determination $\left(\mathrm{R}^{2}\right)$, the significance of regression coefficients and their signs. The dependence of gross return on different factors is explained with variables chosen on the basis of theories of production and costs, correlation analysis and experimentation. Accordingly, the following independent variables considered to explain the gross return in cattle and grain farms were selected for estimation:

\begin{tabular}{ll} 
Cattle Farms & Grain Farms \\
\hline $\begin{array}{l}\text { arable land area } \\
\text { cost of purchased feed }\end{array}$ & $\begin{array}{l}\text { arable land area } \\
\text { cost of purchased seed }\end{array}$ \\
livestock cost & $\begin{array}{l}\text { revised cost of equipment } \\
\text { agricultural works }\end{array}$
\end{tabular}

revised cost of equipment

agricultural works

First, production function analyses were estimated for cattle farms using the linear and the Cobb-Douglas functions. The results of the preliminary regression models showed quite high degrees of determination. The degrees of determination indicated that the linear functions explained $90 \%$ of the variation of gross return. In addition, regression coefficients of almost all the variables were statistically significant at $5 \%$ risk level. The degrees of determination of the Cobb-Douglas functions were, in general, a little lower than for the linear models, even though their degrees of determination still exceeded $90 \%$.

The difference in results between the linear and the Cobb-Douglas function derives from the measuring units of variables employed. Thus, both functions explained the variation in gross return very well. The regression coefficients of the models also proved logical with respect to signs. The results of the models will not be presented in more detail because the main task of the investigation concerns the marginal value product of arable land and its consequences (table 14). For the same reason, the estimates of the parameters of other production inputs included in the models are not of great interest here.

The marginal value product of arable land on cattle farms, at fixed 1986 prices, rose from 
Table 14. Marginal value product of arable land (FIM/ha) on cattle farms, according to the linear and the Cobb-Douglas functions ${ }^{\mathrm{a}}$, at 1986 prices $^{b}$.

\begin{tabular}{lcc}
\hline Year & Linear function & $\begin{array}{c}\text { Cobb-Douglas } \\
\text { function }\end{array}$ \\
\hline 1972 & 2008 & 2370 \\
1976 & $(952)$ & 3381 \\
1980 & 3019 & 3182 \\
$1982-86$ & 2109 & 2505 \\
\hline
\end{tabular}

Notes:

a The assessment of the marginal value product of arable land is based on the use of the formula:

$$
M V P_{X_{i}}=b_{i} \frac{Q}{X_{i}}
$$

b As a deflator, the 1986 cost-of-living index was used.

a level c. 2000 FIM in 1972 to over 3000 FIM until 1980, while during 1982-1986 the marginal product in a linear function fell to 2109 FIM and to 2505 FIM according to the CobbDouglas estimation. These differences in levels (c. 700-900 FIM) compared to the results of 1980 , seem large and unbelievable. The fall in the marginal value product of arable land may partly be due to annual changes in the classification of farms into cattle farms and crop farms, and because of the variation in the crop level. This will be examined more closely later. The results of table 14 permit the general observation that there is a rather good correlation between results of the linear and the Cobb-Douglas functions. For 1976, the regression coefficient of the linear function concerning the marginal value product of arable land did not prove to be statistically significant (identified by brackets).

Farms which specialize in grain farming show considerable variations in the economic results, principally due to weather conditions during the growing seasons. As a result, the estimation of production functions on grain farms proved far more difficult than for cattle farms. As criteria of choice for variables for grain farms, production and cost theories, as well as correlation analyses, were used. On this basis, the following variables were finally chosen: arable land area, cost of purchased feed, revised cost of equipment, and agricultural work cost (farm family plus hired labour). As the fertilizer input has a strong correlation with the arable land area variable (see appendix 4, table 4.2) it was excluded from the model because of the multicollinearity problem. The effect of the fertilizer input in the assessment of the returns from supplementary arable land has been taken into consideration in a later stage (see section 4.5.1).

The explanatory power of the selected variables with respect to the variation of gross return proved rather poor, except for the period 1982-1986. As the annual crop on grain farms may vary considerably, a cross section analysis of three years was chosen for experimentation. In this case, the applicability of the linear function turned out to be poorer than that of the Cobb-Douglas function when the significance of regression coefficients was used as a criterium. Similarly, the applicability of the transcendental function for the estimation of parameters was also tried. Its degree of determination remained lower than that of the Cobb-Douglas function, and the coefficient of the linear term had low or even negative values. In addition, the t-values of the linear terms did not regularly prove statistically significant. Thus, it was decided to abandon the use of this function. Consequently, for the estimation of parameters for grain farms, it was decided that only the marginal value product of arable land given by the Cobb-Douglas function would be used when the estimates of the coefficients of the models were normally statistically significant at $5 \%$ risk (table 15).

Figures in table 15 show that the marginal value product of arable land has remained almost unchanged, except at the turn of the decade. When assessing the results, it has to be noted that in variables, the model, except for arable land, during the two first periods of examination did not prove statistically significant at $5 \%$ risk. Consequently, the marginal value product is in parenthesis. During other 
Table 15. Marginal value product of arable land (FIM/ha) on grain farms according to the Cobb-Douglas function at 1986 prices $^{a}$.

\begin{tabular}{cc}
\hline Years $^{\mathrm{b}}$ & $\begin{array}{c}\text { Marginal value product } \\
\text { of arable land }\end{array}$ \\
\hline $1972-74$ & $(5656)$ \\
$1975-77$ & $(3303)$ \\
$1979-81$ & 2890 \\
$1982-86$ & 4607 \\
\hline
\end{tabular}

Notes:

a The assessment of the marginal value product of arable land is based on the use of the formula:

$$
M V P_{x_{i}}=b_{i} \frac{Q}{X_{i}}
$$

b Farms with the same production structure during the cross section period.

periods under examination, except the final one in 1986, some variables were not statistically significant. The marginal value product of arable land, determined at the average level of production input utilization, remained lower in comparison to other periods under examination during the period 1979-1981, resulting principally from the poor crops of 1979 and 1981 .

The preliminary regression models presented above, the linear and the Cobb-Douglas functions for cattle farms and the CobbDouglas function for grain farms, seem to be well adapted to explain the variation in gross return. The benefit of the Cobb-Douglas function, compared to a linear function, is that it can be useful for the study of the returns to scale in production, as estimated by the sum of the parameters of the production inputs.

The Cobb-Douglas function is based on the assumption that elasticities are constant for all input and output levels. The constant elasticity assumption has, nevertheless, been criticized. Despite this, the use of this function is justified, according to HEADY and. JLLON (1972, p. 97), by stressing that the Cobb-Douglas production function is a useful tool for estimation of the productivity of inputs at their mean levels, even though its functional form does not correctly predict the production surface at the extremes.
In the regression models examined above, differences in the quality of arable land have not been considered. The estimate of the regression parameters shows only one class, i.e. the average land value. For those farms on which the production potential of land is greater or lower than the average, land valuation will be inaccurately estimated. The investigation will therefore now examine whether, on the basis of the research data, it is possible to determine differences due to the quality of agricultural land and take them into consideration in the specification of the regression model.

As was shown in the theoretical part of the study, information on the tax grading and classification of arable land has not been revised since 1967. Even the bookkeeping data do not contain this information. Consequently, it was decided that the average feed unit yield of arable land ( $\mathrm{fu} / \mathrm{ha}$ ) should be used. Yields can be used to indicate the long term production potential of arable land under cultivation. In the profitability survey, the feed unit yield does not include the pasture or straw yield, while only those tops of root crops which have been harvested are included in the yield. The feed unit yield consists mainly of grains, cultivated grass, oil seed crops, and sugarbeet. Only the areas of these crops have been employed in calculating the feed unit yields per hectare.

The change in the regression model caused by the inclusion of the variable describing the quality of arable land will now be considered in more detail. The improvement of the quality of arable land is also expected to increase its marginal value product. The inclusion of the feed unit quantity variable describing the production capacity of arable land in the regression models is accomplished with dummy variables. The Cobb-Douglas function then has the following form:

$\mathrm{Y}=\mathrm{AX}_{1} \mathrm{~B}_{1}+\mathrm{B}_{1}{ }^{\prime} \mathrm{D}^{\prime}+\mathrm{B}_{1}{ }^{\prime} \mathrm{D}^{\prime \prime} \mathrm{X}_{2}{ }^{\mathrm{B}_{2}} \ldots \mathrm{X}_{\mathrm{n}}{ }^{\mathrm{B}_{\mathrm{n}}}$, in which dummy variables are noted with D' and D'. 
The marginal value product from arable land can be assessed with the formula:

$$
\left[\left(\mathrm{B}_{1}+\mathrm{B}_{1}{ }^{\prime} \mathrm{D}^{\prime}+\mathrm{B}_{1}{ }^{\prime} \mathrm{D}^{\prime}{ }^{\prime}\right) / \mathrm{X}_{1}\right] \mathrm{Y}
$$

Dummy variables and their limits are determined in the following way:

if yield (fu/ha) is $<2500 \mathrm{fu}, \mathrm{D}^{\prime}=0, \mathrm{D}{ }^{\prime \prime}=0$, the marginal value product from arable land will be $\left(\mathrm{B}_{1} \mathrm{Y} / \mathrm{X}_{1}\right)$,

if yield $\geq 2500 \mathrm{fu}$, but $\leq 3300 \mathrm{fu}$, $\mathrm{D}^{\prime}=1$, D' $=0$ and the marginal value product from arable land will be $\left[\left(\mathrm{B}_{1}+\mathrm{B}_{1}{ }^{\prime}\right) / \mathrm{X}_{1}\right] \mathrm{Y}$, and if yield $>3300 \mathrm{fu}, \mathrm{D}^{\prime}=0, \mathrm{D}$ ' $=1$, then the marginal value product of arable land will be $\left[\left(\mathrm{B}_{1}+\mathrm{B}_{1}{ }^{\prime}\right) / \mathrm{X}_{1}\right] \mathrm{Y}$.

For estimation, the function is expressed in the form:

$$
\begin{aligned}
\log Y= & \log A+B_{1} \log X_{1}+B_{1}{ }^{\prime} D^{\prime} \log X_{1} \\
& +B_{1}{ }^{\prime} D^{\prime}{ }^{\prime} \log X_{1}+B_{2} \log X_{2}+\ldots \\
& +B_{n} \log X_{n} .
\end{aligned}
$$

The results that have been estimated for cattle and grain farms are presented in appendices 2 and 3 . In addition, correlations between gross return and independent variables for the period 1982-1986 are shown in appendix 4. Quite strong correlations occur be- tween some variables and arable land area, but they are not considered to cause a significant bias on the results, because the degrees of determination of models are clearly higher than the correlation between independent variables.

As a general comment on the results of the regression estimations, it can be noted that the integration of dummy variables for the quality of land has somewhat improved the degrees of determination of models compared to those previously estimated. On the other hand, the dummies did not prove statistically significant in all cases, especially in the case of cattle farms. Yet, the estimates of parameters for the dummies of cattle farms were regularly higher than parameters describing their dispersion (=standard deviation). On the other hand, dummy variables for grain farms were statistically significant at a minimum of $5 \%$ risk during all investigated periods. This demonstrates that the dependence of gross return on yield level (measured mostly as the feed unit yield of cash crops) is clearly higher for grain farms than for cattle farms. In addition, for both types of farms under examination, the estimates of parameters for the dummies, describing the capacity of arable lands to produce yields, increased along with the yield level

\begin{tabular}{|c|c|c|c|c|}
\hline \multirow[b]{2}{*}{ Yield, fu/ha } & \multicolumn{4}{|c|}{ Year } \\
\hline & 1972 & 1976 & 1980 & $1982-1986$ \\
\hline & \multicolumn{4}{|c|}{ Cattle farms } \\
\hline$<2500$ & 2187 & 3017 & 3316 & 4013 \\
\hline $2500-3300$ & 2777 & - & 3542 & 4147 \\
\hline \multirow[t]{2}{*}{$>3300$} & 2900 & 3530 & $\overline{3768}$ & $\overline{4294}$ \\
\hline & \multicolumn{4}{|c|}{ Grain farms ${ }^{a}$} \\
\hline$<2500$ & - & 1660 & 2833 & 4089 \\
\hline $2500-3300$ & - & 2925 & 3390 & 4919 \\
\hline$>3300$ & - & $\overline{3457}$ & 3769 & $\overline{5512}$ \\
\hline
\end{tabular}
(fu/ha). Thus, the results can be considered to be logical in this respect.

Table 16. Marginal value product from arable land (FIM/ha) on cattle and grain farms in different years, at 1986 prices.

Notes:

a The investigation of grain farms covered the years 1972 - 1974, 1975 - 1977, 1979 - 1981, and concerned only those farms which have maintained the same production structure throughout the period. The same procedure has been applied to cattle and grain farms for the years 1982-1986. 
According to table 16 the marginal value product of arable land at fixed prices on cattle farms increased from less than 3000 FIM in 1972 to over 4000 FIM at the end of the research period. The integration of dummy variables seemed to increase the marginal value product of arable land for higher quality land. Marginal value product figures underlined in table 16 indicate the class of yield level to which the investigated farms belong according to the average yield of arable land during the investigated years. Even though the dummy variables for cattle farms did not prove in all cases to be statistically significant, their results were logical, except for 1976 when the dummy parameter was attributed a negative sign. To replace missing information, the marginal value product of 3274 FIM per hectare was used ( = average value of the marginal value product of arable land between the lower and the higher quality class in 1976). The average feed unit yield on cattle farms fluctuated between 2500 and $3300 \mathrm{fu} /$ ha during all investigated years.

On grain farms, the degrees of determination improved in the same way as on cattle farms, along with the inclusion of dummy variables. Also worth noting was the greater increase in the marginal value product of arable farms than for cattle farms, when yield levels increased. The results indicate that the variation of marginal value product is clearly related to the gross return, on which weather conditions also have a considerable effect. In order to even out the weather influences, the production functions for grain farms were estimated on the basis of data for three or five years. The results of the first period of examination had to be abandoned because only 14 farms had maintained the same production structure during the period 1972-1974.

In general, it can be stated that the variation of marginal value product of arable land has been more considerable on grain farms than on cattle farms. The marginal value product from arable land fluctuated, depending on yield level, from c. 1700 FIM to c. 3500 FIM in 1976. In 1980, when the research period included two poor crop years, 1979 and 1981 , the average marginal value of arable land decreased slightly in comparison to the previous period. During 1982 - 1986, the marginal value product of arable land on grain farms exceeded 4000 FIM in the lowest quality class, just under 5000 FIM in the middle case, and slightly over 5500 FIM on farms with a yield level of over $3300 \mathrm{fu} / \mathrm{ha}$.

The marginal value product of arable land seems to have continuously increased on cattle farms during the period of investigation. On grain farms, the marginal value product appeared to be more dependent on yield level (fu/ha), as may be observed by the marginal value product in 1980 . On cattle farms, production is largely based on the processing of pasture feed to milk or meat, in which case the variation in crop quantity and quality is not so likely to be reflected as variations in gross return as in the case of grain farms.

\subsection{Returns from supplementary arable land}

\subsubsection{Returns from supplementary arable land by farm types}

The marginal value product of arable land presented in table 16 has been determined with the estimates of parameters of the production function of gross return in agriculture, at the average level of input utilization. The marginal value product of arable land obtained indicates the growth in gross return generated by one supplementary hectare of arable land, when the use of other production inputs included in the model remains unchanged. The additional return estimated in this way is not entirely available for the acquisition of supplementary arable land, because inputs not included in the model must be taken into account. Therefore, those variable costs which are necessary for production, but were not included as explanatory variables in the regression models, must be subtracted from the marginal value product.

For the assessment of variable costs, the structure of production costs of both types of farms in question must be known. The re- 
quired costs may then be determined. When the variable costs are subtracted from the gross return, the operating margin attributed to the fixed means of production of the enterprise is obtained. In principle, this corresponds to the actual concept of value added ${ }^{3}$ used in the system of national accounts for agriculture proper and applied to the conditions of individual farms. In this study, this correspondence does not exist because the cost of equipment on cattle and grain farms also includes the depreciation of these items.

Operating margin was not initially used as an explanatory variable because some of the variables describing labour input and property were strongly correlated and resulted in multicollinearity problems (see appendix 4 , tables 4.1 and 4.2). For this reason, the solution applied above was preferred. In this approach, the part of variable costs not included in the model is only deducted after the marginal value product of arable land has been determined on the basis of the production function.

Only variable costs that have been excluded from regression models will be considered as variable costs. These are:

- cost of purchased supplies

- cost of reparation and maintenance $(=$ buildings and land improvements)

- other costs.

The costs of commercial supplies include not only purchased expenses, but also changes in stocks of supplies. The increment in stock has been deducted from the purchasing cost of the corresponding supplies and the deduction has been added to them. Supplies consist of, e.g. purchased feed, seeds and fertilizers, plant protection and grain drying, as well as fuels and lubricants. The variable costs of purchased supplies on cattle farms do not include the costs of purchased feed and fertilizers, while on grain farms they do not include the cost of purchased seeds.

The costs of reparation and maintenance

${ }^{3}$ Gross output in agriculture proper (livestock production plus crop production) minus intermediate consumption. arising from buildings and land improvements include the expenses generated by the property items in question. Costs due to buildings and land improvements, except depreciations, have been identified as variable costs on cattle and grain farms. Other costs consist of, e.g. costs of maintenance of drains, fences and farm tracks. For a more detailed examination of the costs concerned see, e.g. ANON. (1986 b).

The assessment of variable costs, at 1986 prices, on cattle and grain farms during the period 1982 - 1986 was made for farms that had maintained the same production structure during the whole period. The average variable costs (FIM/farm) not included in the regression models for cattle and grain farms are shown in appendix 5 in table 1. On cattle farms, the proportion of variable costs in gross return reached $15 \%$, while on grain farms it was $32 \%$. The large percentage on grain farms resulted from the inclusion of purchased fertilizers in the variable costs. The operating margin available for land acquisition is obtained after the percentage of variable costs in gross return has been subtracted from the marginal value product of arable land. Then, the marginal productivity of variable inputs that are not included in the model is assumed to equal one, at the point corresponding to the average arable area of cattle and grain farms.

The reality of this assumption is examined in figures 1 and 2 of appendix 6 . The figures depict the variable costs per farm and per hectare as a function of the arable area - costs which were not included in regression models. They show a linear trend. The variable costs per hectare, in both farm types, appear to decrease as the size of the farm increases. This partially results from the fact that large farms have had the possibility to pay less for their materials than the small ones. In particular, this is the case in purchases of fertilizers and feed until 1985. Until then, taxable standard retail prices were used for fertilizer prices, while standard retail prices from the price lists of feed suppliers were used for mixed feed 
prices (Siltanen and Ala-Mantila 1989, p. 36-37). In practice, considerable discounts from these standard retail prices were available, depending upon the purchased quantity. Consequently, in the agricultural total calculations basic prices of fertilizers are used for fertilizers and wholesale prices are used for feed. Even though the investigated farm types benefit from the advantage of scale, due to the size of farm, it is considered necessary to set the marginal productivity of these variables to one at the point of the average arable area of farm groups. For cattle farms this is $\mathbf{2 4 . 0 9}$ ha and on grain farms 30.85 ha. Determined in this way, the operating margin remaining for land acquisition is called the marginal operating margin (table 17). cluding supplementary incomes, was clearly higher on farms in receipt of state grants than the average value on farms in the farm economy statistics used as comparative material. Thus, Siirola's results correspond, to a large extent, to those for the bookkeeping farms. The results indicated that the average marginal tax rate for additional income in agriculture was $34 \%$ on cattle farms in 1980 and $39 \%$ in 1986. On grain farms the corresponding figures at the same points were $39 \%$ and $45 \%$ (Sirrola 1988, p. 55-58).

On grain farms the average marginal tax was clearly higher than on cattle farms. The supplementary income on grain farms mainly increased the taxable income of the farmer, which because of the unequal distribution of

Table 17. Marginal operating margin of arable land (FIM/ha) on cattle and grain farms in different years, at 1986 prices.

\begin{tabular}{|c|c|c|c|c|}
\hline \multirow[b]{2}{*}{ Yield, fu/ha } & \multicolumn{4}{|c|}{ Year } \\
\hline & 1972 & 1976 & 1980 & $1982-1986$ \\
\hline & \multicolumn{4}{|c|}{ Cattle farms } \\
\hline$<2500$ & 1859 & 2564 & 2819 & 3411 \\
\hline $2500-3300$ & 2361 & 2783 & 3011 & 3525 \\
\hline \multirow[t]{2}{*}{$>3300$} & $\overline{2465}$ & $\overline{3001}$ & 3203 & 3650 \\
\hline & \multicolumn{4}{|c|}{ Grain farms } \\
\hline$<2500$ & & 1129 & 1926 & 2781 \\
\hline $2500-3300$ & & 1989 & $\overline{2305}$ & 3345 \\
\hline$>3300$ & & $\overline{2412}$ & 2563 & $\overline{3748}$ \\
\hline
\end{tabular}

Notes:

a See note to table 16 .

The marginal operating margin in table 17 indicates the pre-tax value, in Finnish marks (FIM), that is available for land acquisition. Because the bookkeeping data used in this study do not permit the determination of the marginal tax rate to cattle and grain farms, the conclusions presented by SiIrola (1988) were used to get after tax values.

Based on the panel data of 341 farms from the period 1980-1984, Siirola examined the effect of an increase in income in agriculture on the marginal tax level, as well as the distribution of the returns from labour between spouses. The average taxable net return, in- income, was already characterized by a highly progressive tax rate.

In this study, the relatively low rates of marginal taxation of $30 \%, 40 \%$, and $50 \%$, were employed, on the basis of which effect of taxation was approximately evaluated. When the marginal operating margin of arable land is multiplied by a coefficient ( 1 minus the marginal tax rate) the net marginal operating margin will be obtained. This can be regarded as the return to arable land under cultivation. Table 18 presents the net marginal operating margin of arable land determined in this way.

Results of table 18 employ the same yield 
Table 18. Net marginal operating margin of arable land (FIM/ha) on cattle and grain farms, at 1986 prices.

\begin{tabular}{|c|c|c|c|c|}
\hline \multirow[b]{2}{*}{ Yield, fu/ha } & \multicolumn{4}{|c|}{ Year } \\
\hline & 1972 & 1976 & 1980 & $1982-1986$ \\
\hline & \multicolumn{4}{|c|}{ Cattle farms } \\
\hline 1. & 1301 & 1795 & 1973 & 2388 \\
\hline 2. $<2500$ & 1115 & 1538 & 1691 & 2047 \\
\hline 3. & 930 & 1282 & 1410 & 1706 \\
\hline 1. & 1653 & 1948 & 2108 & 2468 \\
\hline 2. $2500-3300$ & 1417 & $\underline{1670}$ & $\underline{1807}$ & 2115 \\
\hline 3. & $\overline{1181}$ & $\overline{1392}$ & $\overline{1506}$ & $\overline{1763}$ \\
\hline 1. & 1726 & 2101 & 2242 & 2555 \\
\hline 2. $>3300$ & 1479 & 1801 & 1922 & 2190 \\
\hline \multirow[t]{2}{*}{3.} & 1233 & 1501 & 1602 & 1825 \\
\hline & \multicolumn{4}{|c|}{ Grain farms } \\
\hline 1. & & 790 & 1348 & 1947 \\
\hline 2. $<2500$ & & 677 & 1156 & 1669 \\
\hline 3. & & 565 & $\underline{963}$ & 1391 \\
\hline 1. & & 1392 & 1614 & 2342 \\
\hline 2. $2500-3300$ & & 1193 & 1383 & 2007 \\
\hline 3. & & $\underline{995}$ & 1153 & 1673 \\
\hline 1. & & 1688 & 1794 & 2624 \\
\hline 2. $>3300$ & & 1447 & 1538 & 2249 \\
\hline 3. & & 1206 & 1282 & 1874 \\
\hline
\end{tabular}

1. Marginal tax rate $30 \%$.

2. Marginal tax rate $40 \%$.

3. Marginal tax rate $50 \%$.

levels as used in table 17. The marginal tax rate is assumed to be $40 \%$ on cattle farms, and $50 \%$ on grain farms. The corresponding net marginal operating margins are underlined in table 18. The capitalized value assessed from these figures will be compared later to the market prices of supplementary arable land.

The net marginal operating margins presented here have been carefully determined because in the assessment of taxable net returns, the taxable depreciations of different property items are normally deducted from the returns of the tax year. In this study, only depreciations of equipment have been taken into consideration in the assessment of the marginal operating margin and, thus, in the assessment of the net marginal operating margin of arable land. In addition, the rates of marginal tax used in the study are relatively low.

\subsubsection{Return from supplementary arable land as a function of the size of farm}

The profitability gained from an addition of arable area to an existing farm is often justified by the return derived from intensified use of the production inputs. The production inputs of rather small farms, in particular, can be considered to be used at below full capacity. Consequently, additional arable land area should be most profitable on these farms. The increase in returns from the increase of arable land would gradually decrease, according to the theory, along with the growth of the size of farm (figure 11).

Initially, the dependence of returns on the size of farm was examined with a model explaining the gross return of agriculture in the same way for both cattle and grain farms, as shown above. The farm types concerned were divided in two size classes so that there would be a sufficient number of farms in each group 
Table 19. Marginal value product of arable land (FIM/ha) on cattle and grain farms, at 1986 prices $^{\mathrm{a}}$.

\begin{tabular}{|c|c|c|c|c|}
\hline & \multicolumn{2}{|c|}{ Cattle farms } & \multicolumn{2}{|c|}{ Grain farms } \\
\hline & $<25$ ha & $>25$ ha & $<30$ ha & $>30$ ha \\
\hline No. of farms & 74 & 81 & 90 & 105 \\
\hline \multicolumn{5}{|l|}{ Yield fu/ha } \\
\hline$<2500$ & 4775 & 1361 & 3344 & 4319 \\
\hline $2500-3300$ & 4877 & 1572 & 4106 & 4883 \\
\hline$>3300$ & 5183 & 1701 & 4481 & 5382 \\
\hline
\end{tabular}

Notes:

a The assessments are from 1982-1986.

for statistical analyses. The investigation covered the years 1982-1986.

The results in table 19 indicate that the marginal value product of arable land on cattle farms of less than 25 ha is clearly higher than cattle farms on an average (compare table 16). On the other hand, in the larger farm group (over $25 \mathrm{ha}$ ), the marginal value product from arable land had decreased by a third compared to the small farm group. The results show that the increase of marginal value product generated by the extension of arable area is clearly highest on rather small cattle farms. Along with the extension of arable area, the marginal value product starts to decrease. Therefore, it seems that the economic result of large cattle farms is more dependent on other production inputs and their intensity of use than on the increase of arable area.

Contrary to cattle farms, on grain farms the marginal value product of arable land on farms of less than 30 hectares was at a lower level than the average marginal value product of arable farms as a whole (compare table 16), while for rather large ( $>30 \mathrm{ha}$ ) farms, the marginal value product in different yield classes was approximately the same size as for arable farms on average. The marginal value product of grain farms does not seem to decrease with increasing size class as it does on cattle farms.

Another way of analyzing the dependence of the economic result upon farm size is to examine the average taxable net return and its importance in different farm size classes. In other words, the economic result reveals the part of gross return remaining for interest on capital invested in agriculture. In its assessment, depreciable property items have been revised by the cost-of-living index, and depreciations determined on the same basis. The results are shown in table 20 .

Table 20. Average taxable net return in agriculture (FIM/ha) on the investigated farms by size classes, at 1986 pricesa.

\begin{tabular}{|c|c|c|c|c|}
\hline \multirow{2}{*}{$\begin{array}{l}\text { Farm size } \\
\text { class, ha }\end{array}$} & \multicolumn{2}{|c|}{ Cattle farms } & \multicolumn{2}{|c|}{ Grain farms } \\
\hline & FIM/ha & $\begin{array}{l}\text { No. of } \\
\text { farms }\end{array}$ & FIM/ha & $\begin{array}{l}\text { No. of } \\
\text { farms }\end{array}$ \\
\hline$<20$ & -2796 & 43 & 771 & 40 \\
\hline $20-30$ & 416 & 69 & 1129 & 50 \\
\hline $30-50$ & 1318 & 38 & 2228 & 74 \\
\hline$>50$ & (952) & $(5)^{b}$ & 2498 & 31 \\
\hline
\end{tabular}

Notes:

a The assessments are from 1982-1986.

b Only one farm in this class. 
In both farm types the results indicate an increase in the average taxable net return with increasing farm size. The single exception is the largest class of cattle farm, in which the returns per hectare decreased. The difference in the results for cattle farms in relation to grain farms can be largely explained by the different use of labour. Rather small cattle farms are labour-intensive, which is the reason why uniform pricing of labour input in bookkeeping farms, without consideration of differences in labour efficiency, leads to a negative interest on capital on farms of less than 20 hectares.

The average interest on capital on grain farms is positive in classes of size of farm of less than $20 \mathrm{ha}$, and exceeds 1000 FIM in farms of $20-30$ ha. The net return almost doubles when moving to the $30-50$ ha class, and is about 2500 FIM at its highest level, on farms of over 50 hectares.

The average taxable net return can be used to examine the additional return derived from an increase in arable area. The approach follows that presented by ElSTRAND (1980), according to which the net return of two size classes of farm is first multiplied by the arable area, after which the return of the smaller class is deducted from the return of the larger and the difference obtained is divided by the area differences of the farms concerned ${ }^{4}$. Table 21 presents the returns determined in this way.
The results show that the differential returns for the investigated farms are clearly higher than the average taxable net return. In addition, the differential return of small cattle farms was higher than for larger ones. It may therefore be assumed that arable land is not a scarce production factor on larger cattle farms, and that other means of production, together with matters related to management and organization, have a more pronounced effect on economic results than arable area.

On grain farms, the growth in differential return with an increase in arable land continues to be strong, as does the marginal value product. Nevertheless, on rather large ( $>50 \mathrm{ha}$ ) farms, the growth in differential return has been a little slower than between the smaller size classes of $20-30$ ha and $30-50$ ha.

According to the results, cattle farms are labour-intensive enterprises, and farms of less than 30 hectares benefit the most from supplementary arable land. However, on grain farms, which are capital-intensive, it is still economically justified to increase the arable area on farms of over 50 hectares. These differences in economic results between the farming types are partly explained by their differences in labour-intensity and capitalintensity.

${ }^{4} \frac{(37.5 \times 1318)-(25.2 \times 416)}{37.5-25.2}=3166 \mathrm{FIM} / \mathrm{ha}$.

Table 21. Return of arable land (FIM/ha) on the investigated farms, based on the difference approach, at 1986 prices ${ }^{a}$

\begin{tabular}{|c|c|c|c|c|}
\hline \multirow{2}{*}{$\begin{array}{l}\text { Farm size } \\
\text { class, ha }\end{array}$} & \multicolumn{2}{|c|}{ Cattle farms } & \multicolumn{2}{|c|}{ Grain farms } \\
\hline & $\begin{array}{l}\text { Average } \\
\text { arable } \\
\text { area, ha }\end{array}$ & $\begin{array}{c}\text { Differential } \\
\text { return } \\
\text { FIM/ha }\end{array}$ & $\begin{array}{l}\text { Average } \\
\text { arable } \\
\text { area, ha }\end{array}$ & $\begin{array}{c}\text { Differential } \\
\text { return } \\
\text { FIM/ha }\end{array}$ \\
\hline$<20$ & 14.5 & 4769 & 14.0 & 1606 \\
\hline $20-30$ & 25.2 & $\begin{array}{l}4709 \\
3166\end{array}$ & 24.5 & $\begin{array}{l}1000 \\
4023\end{array}$ \\
\hline $30-50$ & 37.5 & $\begin{array}{l}3160 \\
(12)^{b}\end{array}$ & 39.5 & 2689 \\
\hline$>50$ & 52.1 & $(12)^{\circ}$ & 95.1 & 2689 \\
\hline
\end{tabular}

Notes:

a \& b See notes at table 20 . 


\subsection{Assessment of the capitalized value of supplementary arable land}

\subsubsection{The selection of the capitalization rate}

In the determination of the capitalized value of supplementary arable land, the capitalization rate, as well as the size and duration of return, has a considerable effect on the final result. In principle, the more information available on the returns and market prices of real estates, the more reliable the determination of capitalization rate. According to RYY. NÄNEN (1989, p. 46), the evaluation of return and capitalization rate for the lifetime of a permanent real estate proves problematic in a rapidly changing economy. This also concerns arable land under cultivation.

Murray (1969, p. 183-195) has approached the selection of capitalization rate in two ways. First, land is considered as an ordinary investment, in which case interest is determined according to the returns on alternative investments. Because land is considered to be a safe investment, it is compared to bank deposits, bonds, or stable shares. Alternatively, the interest rate can be determined according to the relationship between the return and market value of arable land. The interest rate determined in this way usually remains lower than in the former case.

SUTER (1976, p. 261-262) considers many economic factors which have an effect on capitalization rate. Among them are the general interest rate, tightness of the money market, risks related to different assets, and annual variations in return. Furthermore, Suter (1976, p. 273-275) divides the factors influencing the interest rate into two groups:

\section{A. Factors increasing the interest rate:}

1. The owner has acquired land for investment.

2. The land has been acquired for intensive production.

3. The interest rate is high either because of a strong demand or a weak supply.
4. The alternative investment possibilities provide high returns and seems to have a good future.

5. Whole farms or supplementary arable land can be acquired quite easily.

6. Investors are not interested in acquiring land for protection against inflation.

7. Land is intended for a specialized production and the return is known to have a considerable annual variation, and there is a high level of risk.

B. Factors decreasing the interest rate:

1. The farm is a family farm, or the land is appropriate for supplementary arable land.

2. Factors other than pure business are related to agriculture.

3. When traditional production, appropriate for the region, is practiced there is a low level of related risk.

4. The farm is located in a good farming region and the land quality is good.

5. The general interest rate is low.

6. Changes in land use methods are possible.

7. The return from alternative investments is low.

8. The acquisition of whole farms and/or supplementary arable land is difficult.

9. Inflation is high and investors are willing to invest in land.

If capitalized value is assessed for a separate farm property item, the choice of capitalization rate depends, in the first place, on the generally accepted interest rate and on the risk related to the use of the property item for production activities and the return to be derived from it. In fact, agricultural cost assessment practice has used different interest rates on capital invested in different property items. A preliminary consideration has been the risk of loss inherent in investments in different property items in agriculture (LAUR and Howald 1957 , p. 110 , Хкомкосн 1962, p. 819). In these studies, the risk of loss is related to the importance of the interest requirement. Also, the interest rates on different property items 
discussed by Meimberg (1956, p. 227) are based on the same grounds. He proposes an interest rate of $3.5 \%$ for long-term capital, $7 \%$ for medium term capital, and $9 \%$ for short term capital. LaUR and Howald (1957, p. $110-111)$ recommend a rate of $3 \%$ for land, to which a $1 / 2 \%$ is added when buildings or land improvements are taken into account. For stocks a $5 \%$ interest rate has been proposed and for forest stands a $31 / 2 \%$ interest rate. In more recent studies in agricultural economics (e.g. Elstrand and SønJu 1978, Ylätalo 1978), an interest of $3 \%$ $4 \%$ was used for the determination of the capitalized value of arable land.

In practice, it may be assumed that every farmer subjectively determines the level of the interest used in the capitalization of the return of supplementary arable land. If the farmer uses an $8 \%$ interest rate, he is not willing to pay as much for supplementary arable land as a person who uses a $3 \%$ interest rate. On the other hand, the farmer who cultivates the land he owns and who values his profession more than alternative ones, may pay a high price for land and may be satisfied with a low labour income if the acquisition of supplementary arable land guarantees the continuation of his professional practices. Economic results may also remain low when, after the acquisition of supplementary arable land, the means of production or inputs are deficient; these being essential prerequisites for the efficient use of supplementary arable land.

A high price paid for supplementary arable land may also result in a change in production structure, in which case production is intensified or extensified according to the circumstances.

Supplementary arable land is real property which keeps its value. Therefore, regarding assessments of the capitalized value, KANERVA (1982, p. 111) proposes the use of a real interest, i.e. one that corresponds to the real interest on long term investments. He argues that the capitalization rate should be chosen according to the real interest, as derived from alternative investment opportunities. The in- vestments considered are banking deposits, savings via the equity market, or state bonds. The safety and liquidity of investments also have an effect on interest. According to KANERVA (1982, p. 113), the liquidity of banking deposits is quite good, but the real interest on capital has remained low or even negative. Conversely, returns from shares have varied quite a lot, in addition to which risk factors related to their acquisition are greater than those related to real estate and banking deposits.

The return from quoted shares in Finland has probably followed a similar development to those in Sweden, where GuSTAFSSON et al. (1978, p. 62-63) report the return from quoted shares to be about $5 \%$ during the period $1950-1974$, but less than $2 \%$ in the 1970 's. Taking into consideration the estimated development of return, they propose an interest rate of about $3 \%$ for land.

The above discussion supports the selection of a relatively low interest rate for the capitalization of the return from supplementary arable land, although in practice, the situation is much more complex. In this study the capitalized value of supplementary arable land is being compared to market prices paid for arable land under cultivation. Therefore, three different capitalization rates were finally selected for use in the calculations.

First, the real interest rate is set at $3 \%$, in which case the acquisition of supplementary arable land is assumed to be self-financed. The second alternative sets the interest at $5 \%$. Supplementary arable land would then be acquired by self-financing and loans. In the third alternative for the capitalization of the return of supplementary arable land, a $7 \%$ real interest rate is used, and the acquisition of supplementary arable land is then considered to be entirely financed with external capital, i.e. via ordinary bank financing. Though a real interest of $7 \%$ seems rather high, it can be justified by the present high interest rates, and by the ever-increasing dependence of agriculture on loans at market rates of interest.

Naturally, for individual farms, such sche- 
matic examples are not valid, but the choice of the interest rate used in assessments depends on whether the farmer is granted a farm loan or an interest-subsidized loan. Their rate of interest in the financing instructions of the Farm Act (ANon. 1989) for zone IV, which corresponds approximately to southern Finland, is principally $6 \%$, and the financing percentage is at most $50 \%$ of the market price.

The capitalization rate can also be determined by comparing the return from arable land to the capital that has been instrumental to the realization of the return during the equivalent period. This approach is hindered by the small annual number of purchases of arable land. According to the Farm Register, an average 14900 hectares of arable land a year were purchased in the country as a whole during the period 1982-1986, which corresponds to little more than $0.5 \%$ of the total arable area.

The market prices indicating the return and value of supplementary arable land are therefore based on the use of marginal information on returns and prices. Consequently, they are much more sensitive to changes, e.g. in the money market situation, than the average returns and prices of real estates.

Land rent, which can be compared to return from supplementary arable land, is considered in the system of national accounting as income transfer, in the same way as dividends, interests, and income taxes of enterprises (BJöRK 1984, p. 460). If the landowner does not lease his land to an outsider, but uses it for his own production activities, it may be considered as a production factor from which a return will be implicitly required, corresponding to the rent that would have been obtained in an alternative use. LAURILA $(1988$, p. 35$)$, who compared rents with market prices of arable land under cultivation, also followed this method. In this case, rents paid for arable land represented approximately $5.6 \%$ of the market price of arable land in southern Finland. The market prices of arable land were determined from the loan statistics of the National Board of Agriculture in
1986. As a result, the real capitalization rate of $3 \%-7 \%$, chosen for the study, was justified. The use of a relatively low real interest is also justified in that the taxable values of the depreciable property items of the investigated farms were transformed to better correspond to their real market values (appendix $1)$.

\subsubsection{Capitalized value of supplementary arable land}

According to Found (1971, p. 23-24), the value of land is derived in one of two ways: (i) return derived from productive activities, or (ii) the price obtained or expected from selling the land. For a farmer, land is an indispensable production factor, the absence of which makes farming impossible. In this respect, the determination of land value is based on the value assessed from the return from supplementary arable land. Land value is therefore considered as the present value of all future returns.

Even though the method of capitalized value discussed above is fundamentally simple, its applicability has been controversial, primarily because of difficulties related to the selection of an appropriate interest rate (see section 3.1.1.). The interest rate used in capitalization may vary considerably in different periods of time, Scofield (1965, p. 46). Thus, in periods of relatively stable return from land, the effective interest on capitalization tends to decrease, thereby increasing land values. The opposite situation prevails when there is uncertainty connected to the return from land.

The duration of the capitalization of return has a significant effect on the present value. Because fixed costs vary over time, the operating margin has to be divided among the factors that participate in its formation (RYYNÄ. NEN 1967, p. 61). This is because the benefit from supplementary arable land equals the operating margin only at the beginning of the appraisal moment. Operating margin does not, however, continue to be as high, because 
the adequacy of existing farm buildings and equipment with respect to cultivation at land to be purchased, as well as fixed costs derived from them, remain at their initial level only as long as they are effective.

With respect to the capitalization of the operating margin, the proportions of the fixed costs of each factor contributing to the formation of the operating margin should first be determined, as well as the number of years required by each factor to adapt to the new situation, MĂKI (1963, p. 3). MÄKI (1963, p. 4) also proposes that the interaction of different factors should be assessed as a weighted average value, giving, as a result, a coefficient by which the operating margin will be multiplied for the determination of the capitalized value of return. According to RYYNÄNEN (1967, p. 136), the coefficient is approximately $10-13$ (according to a $4 \%$ interest rate) at the conveyance of the land.

The coefficient of present value, used for capitalization of return from supplementary arable land, is influenced by the period of time during which the acquisition of supplementary arable land should be financed. On the other hand, the age of the farmer at the moment of acquisition also has an effect on the duration of return from supplementary arable land. If the farmer acquires supplementary arable land at the age of 25 , he theoretically has 30 working years left before he reaches retirement age, according to the present statutes of the Farmers' Pension Act.

According to an investigation by HuHTAMÄKI (1985, p. 19), concerning pensions related to generation transfers on farms undertaken by the Farmers' Social Insurance Institution, the age of those taking over farming was, on an average, 29 years. It is probable that those taking over farming will have expensive loans for at least ten years in connection with the acquisition of their farms. The economic burden of the farm transaction can be estimated to ease only at about the age of 40 , after which some 15 years would be left for the financing of the acquisition of supplementary arable land before retirement.
Tolonen (1985, p. 17), examining middle aged farmers who had acquired supplementary arable land via the Farm Closure Pension system, came to similar conclusions. On the other hand, improvements and replacements of buildings and equipment during the years following the farm transaction increase the fixed costs. Thus, the shortening of the duration of fixed costs together with the brevity of the remaining "active life"' of the farmer, demands a relatively short duration for the determination of coefficients of present value. Therefore, durations of 5, 10, and 15 years for different capitalization rates were chosen for use in this study (table 22).

Table 22. Coefficients of capitalization as functions of the duration of return and interest rate.

\begin{tabular}{lrrr}
\hline \multirow{2}{*}{$\begin{array}{l}\text { Duration of return } \\
\text { years }\end{array}$} & \multicolumn{3}{c}{ Interest rate \% } \\
\cline { 2 - 4 } & \multicolumn{1}{c}{3} & \multicolumn{1}{c}{5} & 7 \\
\hline 5 & 4.580 & 4.329 & 4.100 \\
10 & 8.530 & 7.722 & 7.024 \\
15 & 11.938 & 10.380 & 9.108 \\
\hline
\end{tabular}

The lengthening of the duration of return beyond 10 years considerably increases the coefficient of capitalization. Compared with a ten year duration of return, at 15 years, the coefficient of capitalization will be about $40 \%$ greater when using an interest rate of $3 \%$, about $35 \%$ greater when using an interest rate of $5 \%$, and about $30 \%$ greater when using an interest rate of $7 \%$. In addition, the significance of the interest rate is emphasized with the lengthening of the duration of return. Table 23 presents the annual variation of capitalized value for cattle and grain farms in more detail.

The capitalized value of arable land on cattle farms has steadily increased with time (table 23). In real terms, the value of arable land increased almost one and a half times during the years investigated. During the last period investigated, the capitalized value of arable land varied, according to the ten year duration, from approximately 18000 FIM to little less than 15000 FIM, depending on the in- 
Table 23. Average capitalized value of arable land (FIM/ha) for cattle and grain farms for different durations of return: $\mathrm{a}=5$ years, $\mathrm{b}=10$ years, $\mathrm{c}=15$ years ${ }^{\mathrm{a}}$.

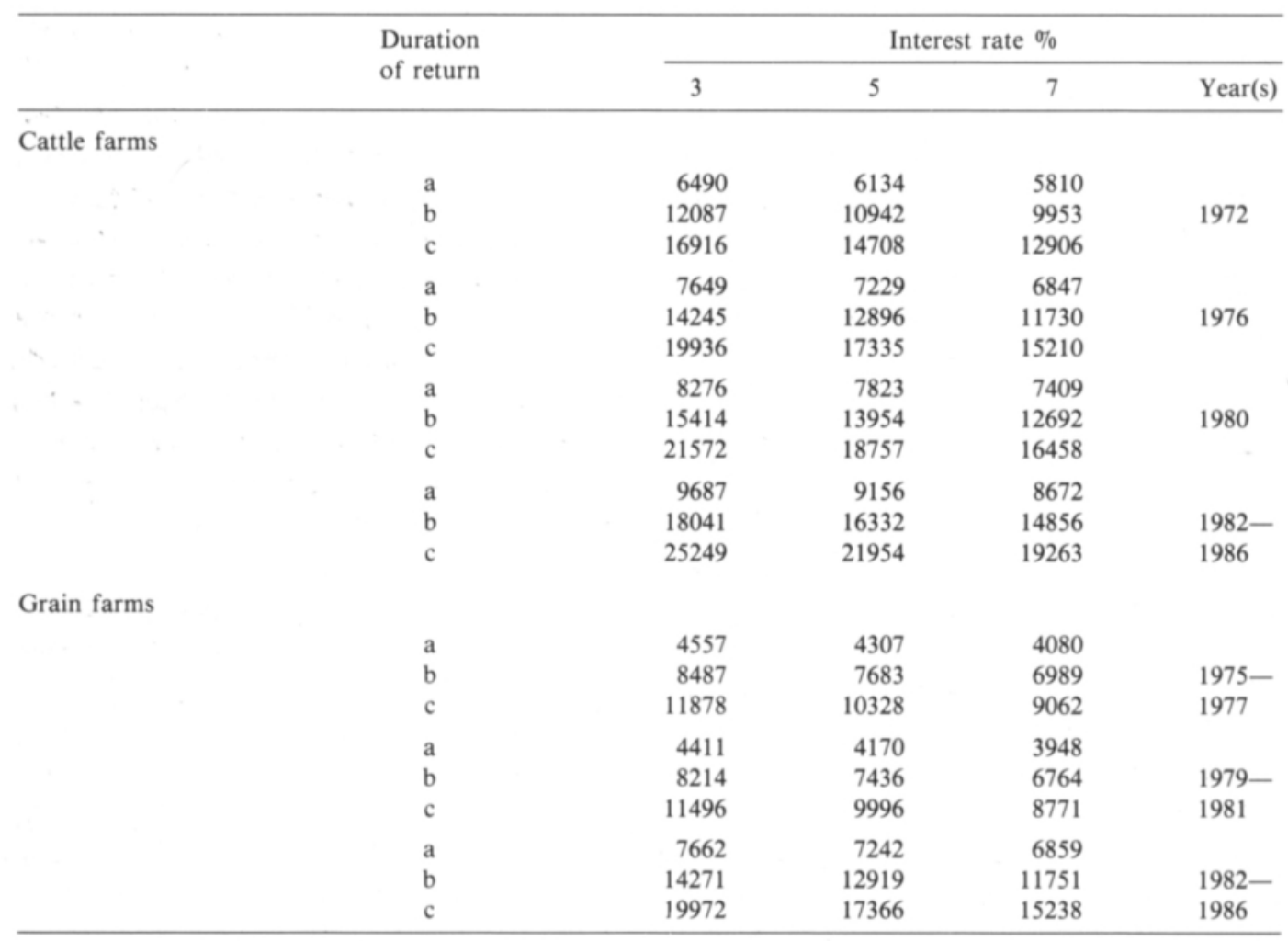

Notes:

a Capitalized values have been calculated by choosing from table 18 the net marginal operating margin that correspond to a $40 \%$ tax rate for cattle farms and a $50 \%$ tax rate for grain farms, which have been capitalized.

terest rate. On the other hand, on grain farms the increase of the capitalized value of arable land was not stable, and was a little lower during the period 1979-1981 than it was during the period 1975-1977, primarily due to poor yields. The capitalized value of both grain and cattle farms was highest during the most re- cently investigated period, and yet the capitalized value of grain farms remained somewhat lower than that of cattle farms, as during previous periods. The real increase in the capitalized value of grain farms was 1.7 -fold, which was clearly more rapid than for cattle farms. 


\section{MARKET VALUE OF SUPPLEMENTARY ARABLE LAND AND ITS DEVELOPMENT IN THE INVESTIGATED REGION}

\subsection{The collection and extent of data}

Price information on arable land under cultivation is available from three different statistical sources: the land acquisition statistics of the National Board of Agriculture; purchases of additional land in accordance with the Farm Act; and the market price register of the National Board of Land Surveying. Each of these statistics has its particular advantages and shortcomings (see e.g. LAURILA 1986 , p. 15-16). In this study, the market price register was chosen for price information on arable lands. In principle, it includes land acquisitions of the National Board of Agriculture and transactions of supplementary arable lands financed in accordance with the Farm Act. The data concern transactions of over 2.0 hectares, made during 1982-1986, consisting principally of cultivated land.

Another set of data on market prices consists of price statistics on land purchased for the state by the National Board of Agriculture. Because the purchasing activities of the National Board of Agriculture have continued for so long, information from the market price statistics is used for the description of the price development of arable land during 1972-1986.

The National Board of Land Surveying's real estate market price register contains the following information on all arable land transactions:

- time of conveyance

- location of the object of transaction
- the area of land involved

- total market price and unit price

- buildings on the area

- classification of buyers and sellers.

In addition, information on the distance between the lot and the additional real estate is also available for some transactions. Yet, the market price register does not include information on soil quality, the workability of the land, drainage, or other related activities. Transactions between relatives are also omitted from the market price register.

In the research region of southern Finland, the number of arable land transactions has continuously increased. In 1982, 197 arable land transactions were specifically of cultivated land ${ }^{1}$. In 1986, the number of these transactions reached 271 , when land divisions and obviously underpriced transactions were discarded from the material. In 1982, prices of under $1500 \mathrm{FIM} / \mathrm{ha}$ were considered to be underpriced. The limit of underpricing was raised in proportion to the rise of the cost-ofliving index. Some of the transactions also included buildings, the values of which were not declared separately. The number of transactions of supplementary arable land and the areas involved are given in table 24 .

The table indicates a slight increase in the mean area of transactions concerning solely supplementary arable land. On the other hand, there has been a slight decrease in the mean area of transactions including buildings. During the investigated period, the area of transactions of supplementary arable lands

\footnotetext{
1 In this study these transactions are called supplementary purchases, although the information whether the purchase concerned supplementary area was not available for each case.
} 
Table 24. Transactions of supplementary arable land by number and size, 1982-1986.

\begin{tabular}{|c|c|c|c|c|c|c|c|}
\hline \multirow[t]{2}{*}{ Year } & \multicolumn{2}{|c|}{ No buildings } & \multicolumn{2}{|c|}{ With buildings } & \multicolumn{3}{|c|}{ Total } \\
\hline & No. & $\begin{array}{c}\text { Mean } \\
\text { area } \\
\text { ha }\end{array}$ & No. & $\begin{array}{c}\text { Mean } \\
\text { area } \\
\text { ha }\end{array}$ & No. & $\begin{array}{c}\text { Mean } \\
\text { area } \\
\text { ha }\end{array}$ & $\begin{array}{c}\text { Total } \\
\text { area } \\
\text { ha }\end{array}$ \\
\hline 1982 & 156 & 4.91 & 41 & 7.61 & 197 & 5.48 & 1078.6 \\
\hline 1983 & 176 & 5.07 & 32 & 7.90 & 208 & 5.50 & 1144.5 \\
\hline 1984 & 192 & 4.87 & 25 & 5.39 & 217 & 4.93 & 1070.4 \\
\hline 1985 & 220 & 5.44 & 36 & 6.57 & 256 & 5.60 & 1432.7 \\
\hline 1986 & 222 & 5.09 & 49 & 6.28 & 271 & 5.30 & 1437.1 \\
\hline
\end{tabular}

has increased from c. 1100 hectares to 1440 hectares a year in southern Finland. The average arable land area entering the market during the period 1982-1986 was $1233 \mathrm{ha} /$ year, which represents slightly over $0.1 \%$ of the total arable land area in southern Finland (1.1 mill. ha). Almost 6200 hectares of land were exchanged in arable land transactions. Even though most transactions concern only supplementary arable lands, a considerable number of transactions included buildings. Their part in the exchanged total area increased from $13 \%$ to $29 \%$. The annual area transac- tions of supplementary arable land including buildings is shown as follows:

\begin{tabular}{ll}
$\frac{\text { Year }}{1982}$ & Total \\
\cline { 2 - 2 } 1983 & 312 ha \\
1984 & 253 ha \\
1985 & 135 ha \\
1986 & 237 ha \\
308 ha.
\end{tabular}

Table 25 presents the number and average area of transactions of supplementary arable land by Agricultural Advisory Centers. It can been seen that most transactions were made

Table 25. Number of transactions of supplementary arable land and average area (ha) by Agricultural Advisory Centers in southern Finland, 1982-1986.

\begin{tabular}{|c|c|c|c|c|c|c|c|c|c|}
\hline \multirow{2}{*}{$\begin{array}{l}\text { Agric. } \\
\text { Adv. } \\
\text { Center }\end{array}$} & \multicolumn{3}{|c|}{ No buildings } & \multicolumn{3}{|c|}{ With buildings } & \multicolumn{3}{|c|}{ All transactions } \\
\hline & No. & ha & $\begin{array}{c}\text { Total } \\
\text { ha }\end{array}$ & No. & ha & $\begin{array}{c}\text { Total } \\
\text { ha }\end{array}$ & No. & ha & $\begin{array}{c}\text { Total } \\
\text { ha }\end{array}$ \\
\hline Uusimaa & 101 & 5.31 & 536.49 & 26 & 7.66 & 199.26 & 127 & 5.79 & 735.75 \\
\hline $\begin{array}{l}\text { Nylands } \\
\text { Svenska }\end{array}$ & 55 & 6.91 & 380.22 & 7 & 6.42 & 44.97 & 62 & 6.86 & 425.90 \\
\hline Vars.-Suomi & 215 & 5.27 & 1132.26 & 26 & 8.21 & 213.51 & 241 & 5.58 & 1345.77 \\
\hline $\begin{array}{l}\text { Finska Hus- } \\
\text { hállningss. }\end{array}$ & 5 & 6.88 & 34.40 & 2 & 14.75 & 29.50 & 7 & 9.13 & 63.90 \\
\hline Satakunta & 172 & 4.45 & 765.42 & 46 & 5.81 & 267.32 & 218 & 4.74 & 1032.74 \\
\hline Pirkanmaa & 81 & 4.67 & 373.20 & 8 & 7.26 & 58.07 & 89 & 4.90 & 345.27 \\
\hline $\begin{array}{l}\text { Province } \\
\text { of Häme }\end{array}$ & 126 & 5.42 & 682.96 & 39 & 5.89 & 229.56 & 165 & 5.53 & 912.52 \\
\hline Ită-Hăme & 45 & 6.29 & 283.23 & 9 & 10.40 & 93.63 & 54 & 6.98 & 376.86 \\
\hline Kymenlaakso & 97 & 4.82 & 467.37 & 10 & 6.32 & 63.18 & 107 & 4.96 & 530.55 \\
\hline Etelä-Karjala & 69 & 3.76 & 259.10 & 10 & 4.46 & 44.61 & 79 & 3.84 & 303.71 \\
\hline $\begin{array}{l}\text { Southern } \\
\text { Finland } \\
\text { Total }\end{array}$ & 966 & 5.09 & 4919.65 & 183 & 6.80 & 1243.61 & 1149 & 5.36 & 6163.26 \\
\hline
\end{tabular}


in the Agricultural Advisory Center areas of Varsinais-Suomi and Satakunta. The quantity of sold land in these areas exceeded 1000 hectares during the five years investigated. The smallest number of transactions reported by the market price register was observed in the area of Finska Hushållningssällskapet. In the Agricultural Advisory Center areas of ItäHäme and Etelä-Karjala the number of transactions also remained small; nevertheless, the total area of transactions of supplementary arable lands exceeded 300 hectares.

Thus, 966 transactions of solely supplementary arable land were concluded during the period 1982 - 1986. The average area was 5.09 ha, while in transactions of supplementary arable land including buildings the area was considerably larger, 6.8 ha. During the investigated period, there were 183 transactions of supplementary arable lands including buildings and 1244 ha of land were exchanged, which represents about a fifth of the total area of supplementary arable land.
The activities of land acquisition by the National Board of Agriculture are principally controlled by the Farm Act, implemented on April 1, 1977. The National Board of Agriculture is able to acquire land areas destined for the expansion of farms by making voluntary transactions or by exchanging land. The cost of transactions, which must not exceed the current price, is paid from the funds of the Agricultural Development Fund. Land which is not able to be used immediately for the expansion of farms can also be purchased. Nevertheless, the main objective is to acquire land that is suitable as additional land or for improving the structure of holdings (ANON. 1977). When making purchases, the priorities are for farms whose arable land area is considerable and for land related to the farm closure pension scheme. Table 26 shows how the purchases of arable land by the National Board of Agriculture in the bookkeeping region of southern Finland developed during the period 1972-1986.

Table 26. Quantity of arable land (ha) purchased by the National Board of Agriculture in southern Finland, $1972-1986$.

\begin{tabular}{|c|c|c|c|c|c|}
\hline Year & $\begin{array}{l}\text { Total } \\
\text { trans- } \\
\text { actions }\end{array}$ & ha & $\begin{array}{c}\text { I cl.a } \\
(>120 \text { pts }) \\
\text { ha }\end{array}$ & $\begin{array}{c}\text { II cl.a } \\
(70-120 \text { pts }) \\
\text { ha }\end{array}$ & $\begin{array}{c}\text { III cl.a } \\
(<70 \text { pts }) \\
\text { ha }\end{array}$ \\
\hline 1972 & 37 & 299.40 & 118.15 & 140.55 & 40.70 \\
\hline 1973 & 20 & 209.27 & 97.38 & 98.37 & 13.70 \\
\hline 1974 & 65 & 657.23 & 412.87 & 215.96 & 28.40 \\
\hline 1975 & 70 & 529.49 & 247.56 & 241.14 & 40.79 \\
\hline 1976 & 50 & 384.21 & 147.62 & 190.49 & 46.10 \\
\hline 1977 & 55 & 638.27 & 263.00 & 303.15 & 72.12 \\
\hline & & & \multicolumn{2}{|c|}{ Subsurface drainage } & ige \\
\hline 1978 & 77 & 849.40 & \multicolumn{2}{|c|}{200.90} & \\
\hline 1979 & 80 & 903.90 & \multicolumn{2}{|c|}{264.40} & \\
\hline 1980 & 73 & 667.85 & \multicolumn{2}{|c|}{84.81} & \\
\hline 1981 & 57 & 648.52 & \multicolumn{2}{|c|}{244.24} & \\
\hline 1982 & 40 & 448.43 & \multicolumn{2}{|c|}{167.14} & \\
\hline 1983 & 32 & 249.52 & \multicolumn{2}{|c|}{88.82} & \\
\hline 1984 & 35 & 407.32 & \multicolumn{2}{|c|}{172.70} & \\
\hline 1985 & 34 & 212.67 & \multicolumn{2}{|c|}{30.50} & \\
\hline 1986 & 37 & 469.45 & \multicolumn{2}{|c|}{310.36} & \\
\hline \multicolumn{6}{|c|}{$\begin{array}{l}\text { Period } \\
1972-\end{array}$} \\
\hline 1986 & 762 & 7574.90 & & & \\
\hline
\end{tabular}

Notes:

a These points are from tax grading during the period 1972-1977. 
Table 26 shows an increase in land purchases until 1979 and a decrease thereafter. The number of land purchases was particularly small in 1983 and 1985 when the state purchased less than 250 ha annually. The annual average quantity of arable land purchased by the state was 505 ha during the investigated period, i.e. less than half of the annual area of supplementary arable land purchased according to the market price register. In the land acquisitions of the National Board of Agriculture, the quality of arable land has been given as an index according to the tax grading. Since 1978, transactions have been classified according to whether arable land has open or subsurface drainage. Arable land is considered to be subsurface drained, if over half of the area is so drained.

The arable land purchased by the National Board of Agriculture has mostly been open drained, except in 1986. The area of land purchased with subsurface drainage amounted to 1563 hectares during the period 1978-1986, which represents $32 \%$ of the total area of purchased arable land. The relation between open and subsurface drained arable land varies annually. Naturally, this has an effect on prices weighted by surface areas. Class I included $47.3 \%$ of the arable land purchased during 1972-1977, class II $43.8 \%$, and class III $8.9 \%$.

\subsection{Price level of supplementary arable land and its development}

\subsubsection{Questions concerning the use and assessment of data on market prices}

In the market data approach, the value of real estate is defined, in most cases, according to market price data. This approach requires that enough observations on free market transactions are available and that they are sufficiently homogenous. In addition to price comparisons, the market value of arable land under cultivation can be determined by using expert appraisals of the price level. This is the approach applied by the National Board of
Agriculture in its land purchases; experts in agricultural administration appraise the property items of the real estates. The value of arable land is then based on the subjective view of the assessor concerning local current price.

The market value of arable land depends on whether it is purchased together with a farm as a whole, or as supplementary arabie land. The value of supplementary arable land is determined according to the additional benefit it brings, which may be considerable in individual cases. When connected with a farm as a whole, the value of arable land is determined according to an average level of benefit. In the market price data, the price of arable land purchased in connection with a farm as a whole is determined by subtracting the value of other property parts from the total market price. If the total value of property parts is higher than the market price actually paid, the value of property parts is reduced by the same proportion (MÄKI 1964, p. 105).

This situation is common in appraisals of farms as a whole based on the summation of separately assessed property parts. After a wholesale discount on the total value of property parts, the current price can be appraised. The discount is lower, the greater the proportion of arable land of the total area. Correspondingly, the discount percentage is increased when there is a large proportion of forest land and buildings in the total area. Transactions of arable land alone contain little or no discount, depending on the scale of the transaction (compare RYYNÄNEN 1978 b, p. 11).

In appraisals based on market prices, some compromises are made concerning the representativeness of the data, otherwise the number of observations would not be sufficient. According to Wilala (1976, p. 15-21), a representative real estate transaction meets the following requirements:

- similarity,

- equivalence of the type of real estate,

- consistency of potential use,

- similarity of size, 
- same location,

- congruence of transaction time, and

- freedom of transaction.

Compulsory auctions, family transactions, and transactions including so-called "backhanders"' are not included in the market price data. Even though the non-representative transactions could be discarded on the abovementioned grounds, the material would still contain variations in unit prices that derive from the heterogeneity of the objects in transactions and from the individual decisions of the parties involved. The variations in market prices are represented by average figures, as well as by parameters for dispersion and for skewness in distribution. The probable market price, concerning comparable transactions, can be indicated as either arithmetical average price, area-weighted average price, mode price, or median price.

In fact, the probable market price corresponds to the mode price, which signifies the class containing most observations. Mode is adapted for use with classified materials, and the choice of the interval of the class has an effect on its numerical value.

The arithmetical average value, the weighted average price, and median are adapted for continuous data. The median price divides the data in half, thus, it is not as sensitive to extreme values as are average values. Often just low extreme values are non-representative (containing hidden relationship, black market price, etc.). Wilala (1976, p. 21) recommends the use of the median price as the market value.

However, matters related to appraisals support the use of the arithmetical average value. The average value is required for the calculation of several statistical parameters. The areaweighted average value takes into consideration the size of the transaction. Consequently, high unit prices paid for small areas do not raise the average price as much as the use of the arithmetical average value would do. On the other hand, a few large transactions re- ceive considerable weight when a small material is weighted.

One prerequisite for the application of the market data approach is the equivalence of the size of observations and the objects appraised. In this case, the market value of additional areas should be determined on the basis of transactions already made in the district concerning supplementary arable land of similar areas. In practice, all transactions of supplementary arable land have to be considered for the appraisal, because the total number of transactions is low.

In this study, an approach was selected in which the total market price of an arable land area is divided by its area. The distribution of the unit price (FIM/ha), determined in this way, is described by averages and dispersion measures. The average figure aims to represent the average size or quality of the variable, or the position of the distribution in the continuum. The dispersion describes the scatter around the average figure.

Average prices, determined in the following way, are employed in this investigation:

1. arithmetical average price $\bar{x}=\frac{\Sigma x_{j}}{\mathrm{~N}}$

2. area-weighted average price $\bar{x}=\frac{\Sigma p_{j} x_{j}}{\Sigma p_{j}}$,

in which

$\mathrm{x}_{\mathrm{j}}=$ price per hectare transacted

$\mathrm{p}_{\mathrm{j}}=$ area of the additional land

$\mathrm{N}=$ number of transactions.

3. median price which divides the market price data in half. If the number of observations is even, the median price is the mean value of the two middle observations.

Dispersion figures

1. standard deviation $s=\sqrt{\Sigma\left(x_{j}-\bar{x}\right)^{2} /(n-1)}$

2. interval of variation $w=\left(x_{j}^{\min }, x_{j}^{\max }\right)$ 


\subsubsection{Price of supplementary arable land and its development according to the market price register}

The prices of supplementary arable land, appraised on the basis of data from the market price register, and expressed with different average figures for the bookkeeping region of southern Finland, are presented in table 27. A strong variation in the price of supplementary arable land in districts belonging to different Agricultural Advisory Centers is apparent. The year 1982 has been chosen for closer examination, because it is the first year from which data from the market price register concerning the whole year are available. Appraisals are made on the same basis as those for subsequent years, even though their conclusions will not be presented in detail.
The median price remained lower than the average prices. Thus, there is skewness in the distribution to the right, i.e. there are relatively more transactions of low per hectare price in the data. Consequently, the choice of approach has a considerable effect on the final results of the search for the average price and probable market price of arable land.

The price of supplementary arable land proved highest in the Agricultural Advisory Center of Varsinais-Suomi (24 650 FIM/ha), while in Satakunta, the price was also almost on the same level. The price of supplementary arable land was lowest in the Agricultural Advisory Centers of Etelä-Karjala, Kymenlaakso, and Pirkanmaa, where it varied from 13900 FIM to 14700 FIM per hectare.

Standard deviations of per hectare prices were relatively large. The standard deviation

Table 27. Price of arable land (FIM/ha) in transactions of solely supplementary arable land in 1982 in southern Finland, calculated by different measures.

\begin{tabular}{lrccccc}
\hline $\begin{array}{l}\text { Agricultural } \\
\text { Advisory } \\
\text { Center }\end{array}$ & No. & $\begin{array}{c}\text { Arithmetical } \\
\text { average } \\
\text { price }\end{array}$ & $\begin{array}{c}\text { Standard } \\
\text { deviation }\end{array}$ & $\begin{array}{c}\text { Variance } \\
\% \text { from } \\
\text { the average } \\
\text { price }\end{array}$ & $\begin{array}{c}\text { Weighted } \\
\text { average } \\
\text { price }\end{array}$ & $\begin{array}{c}\text { Median } \\
\text { price }\end{array}$ \\
\hline Uusimaa & 17 & 17912 & 4518 & 25.7 & 17114 & 17200 \\
Nylands Svenska & 7 & 17571 & 6628 & 37.7 & 16219 & 15500 \\
Varsinais-Suomi & 44 & 24725 & 9253 & 37.4 & 24650 & 23650 \\
Satakunta & 26 & 23708 & 8537 & 36.0 & 24344 & 23250 \\
Pirkanmaa & 14 & 14671 & 4981 & 33.9 & 14720 & 13850 \\
Province of Häme & 14 & 17571 & 6252 & 35.6 & 18247 & 17500 \\
Itä-Hăme & 7 & 16786 & 10931 & 65.1 & 16907 & 14000 \\
Kymenlaakso & 16 & 12831 & 5072 & 39.0 & 14217 & 14000 \\
Etelä-Karjala & 11 & 14182 & 5011 & 35.3 & 13877 & 15000 \\
Southern Finland & 156 & 19628 & 8602 & 43.8 & 19872 & 17000 \\
\hline
\end{tabular}

Table 27 shows that the area-weighted average price (19872 $\mathrm{FIM} / \mathrm{ha})$ is a little higher than the price determined as an arithmetical average value (19628 FIM/ha). In fact, the average price of arable land represents the average price of arable land for sale, for which the price of each hectare of arable land is assessed separately, i.e. by weighting the unit area price of each transaction by the area for sale. As for the arithmetical, non-weighted average value, it represents the average price of transactions of arable land. Transactions of areas of different size do not have an effect. in the whole data was 8602 FIM. The largest dispersion was noted in the Agricultural Advisory Center of Itä-Häme which had the smallest number of observations.

Figure 12 shows the price development of supplementary arable land by Agricultural Advisory Centers and a sharp price rise during the period 1982-1986. During the period in question, the price of arable land increased by $60 \%$ in southern Finland. On the other hand, in 1986 the nominal price level of arable land increased at a yearly rate of $12.5 \%$, as determined by the formula calculating the 


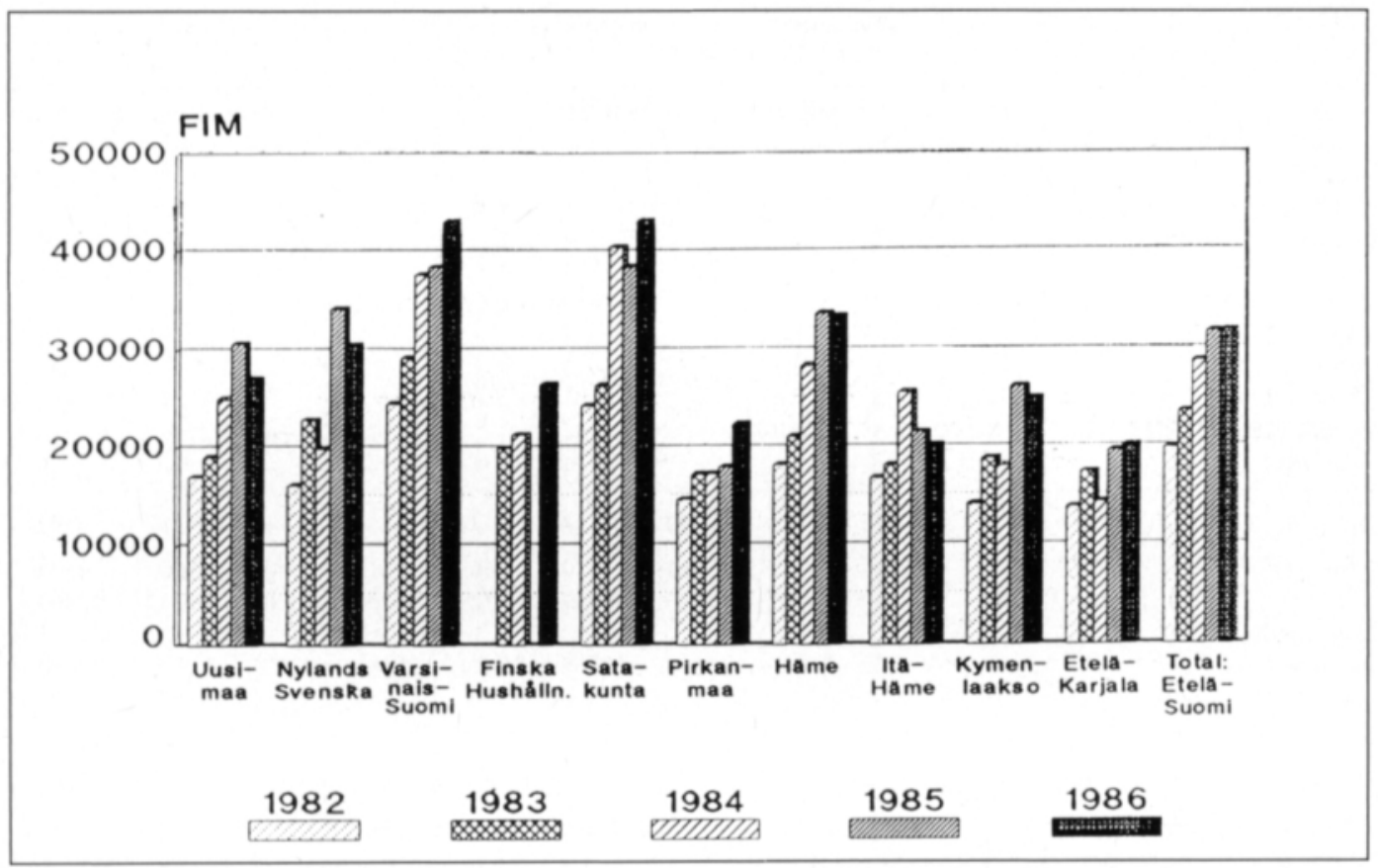

Figure 12. Weighted average price of transactions of supplementary arable land (FIM/ha) by Agricultural Advisory Centers in southern Finland, 1982-1986.

compound interest of the value for the first and the last year ${ }^{2}$.

In the regional examination, the Agricultural Advisory Centers of Satakunta and Varsinais-Suomi are of interest because the prices of supplementary arable land rose during each year investigated and the price levels were the highest. The prices of transactions of supplementary arable land were the lowest in Etelä-Karjala, Itä-Häme, and Pirkanmaa.

When examining prices and their development by Agricultural Advisory Centers, it must be kept in mind that there have been few annual transactions in some of the districts. As a result, a more reliable picture of the price development can be gained from centers with the greatest number of transactions. Table 28 describes the classification of transactions of supplementary arable land in eight different price classes with respect to the central year of the investigated period.

$$
2\left[\left(\frac{y_{n}}{y_{o}}\right)^{\left(\frac{1}{n-1}\right)}-1\right] \times 100, \begin{aligned}
& \text { in which } \mathrm{y}_{\mathrm{n}}=\text { value of the } \\
& \text { last year, and in which } \mathrm{y}_{\mathrm{o}}= \\
& \text { value of the first year }
\end{aligned}
$$

Most transactions were made in Satakunta, Varsinais-Suomi, and Uusimaa. In addition, it is worth noting that in the first two centers almost half of the transactions belonged to the upper price class. In Finska Hushållningsällskapet only one transaction was made. Similarly, in Itä-Häme and EteläKarjala only a few transactions were made in 1984. Despite these inadequacies, a conception of the price differences of arable land in different centers can be formed.

Earlier in this chapter, the price of supplementary arable land and its development was examined as nominal price. This indicated the regional price differences and the changes in price development. However, inflation can considerably alter the picture conveyed by prices and their development. Therefore, in figure 13, the price level of supplementary arable land and its development is based on 1986 prices. The cost-of-living index has been used as the deflator.

The figure shows that the real price of supplementary arable land was highest in 1985 . The following year the average price of ara- 
Table 28. Division of transactions of supplementary arable land (without buildings) in price classes and lowest and highest per hectare prices by Agricultural Advisory Centers in 1984.

\begin{tabular}{|c|c|c|c|c|c|c|c|c|c|c|c|}
\hline $\begin{array}{l}\text { Price } \\
\text { FIM/ha }\end{array}$ & $\begin{array}{l}\text { Uusi- } \\
\text { maa }\end{array}$ & $\begin{array}{c}\text { Nyl. } \\
\text { svenska }\end{array}$ & $\begin{array}{l}\text { Vars. } \\
\text { Suomi }\end{array}$ & $\begin{array}{c}\text { Finska } \\
\text { Hush. }\end{array}$ & $\begin{array}{l}\text { Sata- } \\
\text { kunta }\end{array}$ & $\begin{array}{c}\text { Pirkan- } \\
\text { maa }\end{array}$ & Hăme & $\begin{array}{l}\text { Itä- } \\
\text { Häme }\end{array}$ & $\begin{array}{c}\text { Kymen- } \\
\text { laakso }\end{array}$ & $\begin{array}{c}\text { Etelä- } \\
\text { Karjala }\end{array}$ & $\begin{array}{c}\text { Southern } \\
\text { Finland } \\
\text { total }\end{array}$ \\
\hline$<15000$ & 1 & 3 & 2 & - & 2 & 4 & 2 & 2 & 2 & 5 & 24 \\
\hline $15000-19999$ & 3 & 5 & 1 & - & 2 & 1 & 5 & 1 & 6 & 5 & 29 \\
\hline $20000-24999$ & 5 & 1 & 3 & 1 & 2 & 4 & 6 & 1 & 2 & 1 & 26 \\
\hline $25000-29999$ & 10 & 1 & - & - & 5 & 4 & 5 & - & 1 & 1 & 27 \\
\hline $30000-34999$ & 2 & 1 & 8 & - & 2 & 2 & 3 & 2 & - & - & 20 \\
\hline $35000-39999$ & 3 & - & 4 & - & 3 & - & 3 & 2 & 1 & - & 16 \\
\hline $40000-44999$ & - & - & 2 & - & 4 & - & 3 & - & 1 & - & 10 \\
\hline$>45000$ & - & 2 & 16 & - & 17 & 1 & 4 & - & - & - & 40 \\
\hline Total & 24 & 13 & 36 & 1 & 37 & 16 & 31 & 8 & 14 & 12 & 192 \\
\hline Min & 8831 & 12889 & 5269 & 23132 & 10961 & 4324 & 5463 & 9613 & 9682 & 8602 & 4324 \\
\hline Max & 39568 & 51958 & 92869 & 23132 & 80663 & 56967 & 65729 & 38364 & 43008 & 27242 & 92869 \\
\hline $\begin{array}{l}\text { Weighted } \\
\text { average price }\end{array}$ & 25120 & 19996 & 37713 & 21400 & 40554 & 17368 & 28471 & 25691 & 18105 & 14373 & 28850 \\
\hline
\end{tabular}

ble land in the research region was c. 1000 FIM/ha lower.

The average real price of arable land in the research region varied from 25000 FIM to 33000 FIM during the period 1982-1986. Though the real price of arable land mainly decreased during the last year, the price of arable land reached its peak value in 1986 in Varsinais-Suomi. During this same year, the price of arable land exceeded $43000 \mathrm{FIM} / \mathrm{ha}$ in Satakunta and Varsinais-Suomi. In these areas, the per hectare prices of arable land were the highest in each year. The next highest prices were found in the Agricultural Advisory

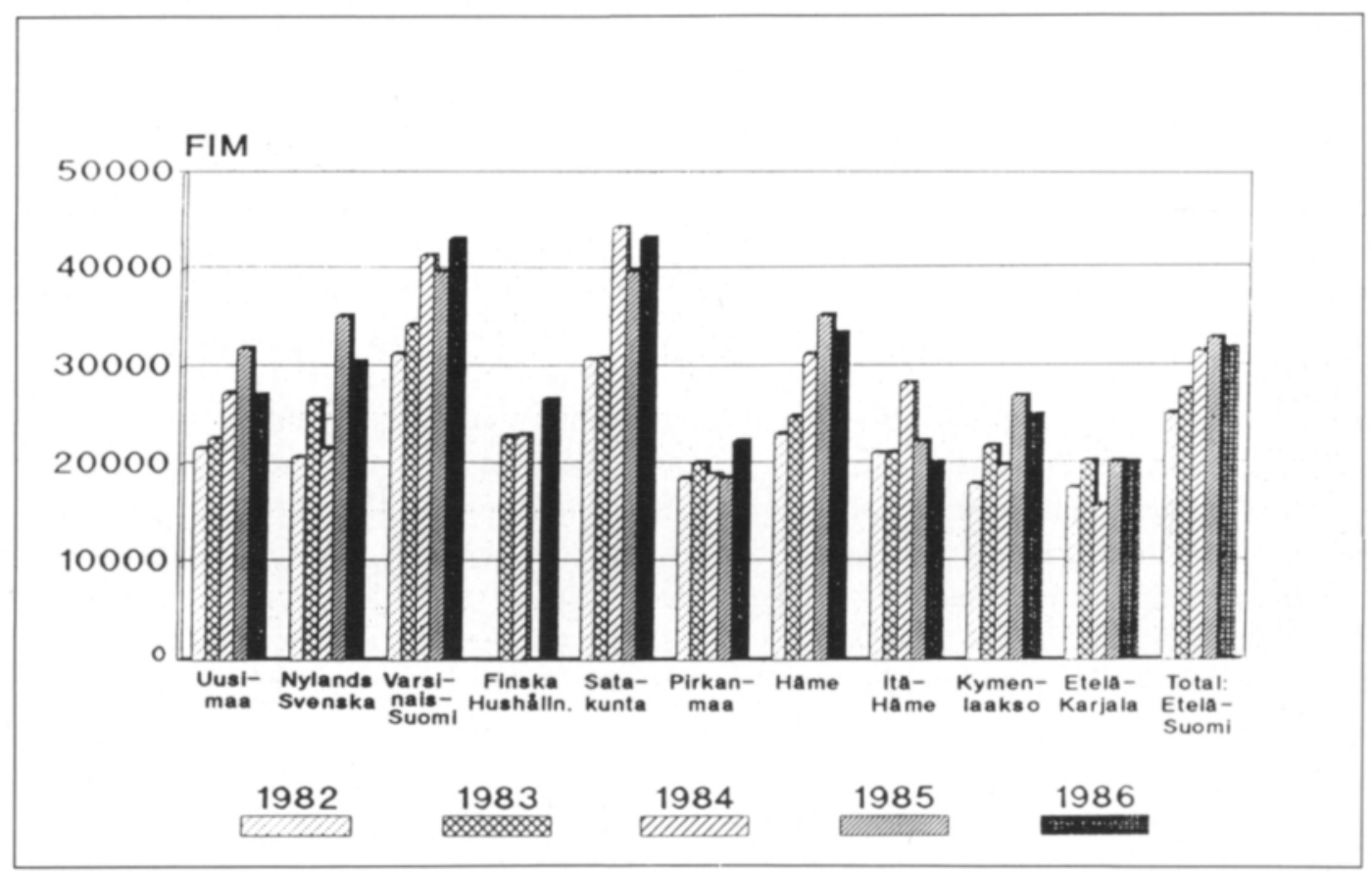

Figure 13. Real weighted average price (FIM/ha) of transactions of supplementary arable land, by Agricultural Advisory Centers, in southern Finland, 1982-1986, at 1986 prices. 
Center of Häme, the annual price variation being between $23000 \mathrm{FIM} / \mathrm{ha}$ and 35000 FIM/ha. On the other hand, in Pirkanmaa the prices (18600-22500 FIM/ha) remained lower than those of Häme as a whole. The lowest prices for arable land were paid in ItäHäme, Etelä-Karjala, and Kymenlaakso. The prices in these areas and Pirkanmaa were clearly lower than in the Finnish and Swedish speaking areas of Uusimaa.

In addition to the transactions of solely arable land examined above, the market price register also includes transactions of supplementary arable land with buildings. The number of transactions including buildings developed in the following way:

$\begin{array}{cc}\frac{\text { Year }}{1982} & \text { Number of transactions } \\ 1983 & 41 \\ 1984 & 32 \\ 1985 & 25 \\ 1986 & 36 \\ & 49 .\end{array}$

In three cases, transactions included only dwellings. Dwellings and farm buildings were included in 14 transactions, farm buildings in 38 transactions, and other buildings in 128 transactions. There was no specification of the value of buildings, but they were included in the price declared in the market price register. Table 29 indicates the weighted average prices of transactions of supplementary arable land including buildings, at 1986 prices.
The prices in transactions of supplementary arable land areas including buildings were not significantly higher than those in transactions of solely arable land areas, during 1982 and 1983. However, during the period 1984-1986 buildings, especially dwellings and farm buildings, have been a source of considerable price rises. It is worth noting that the real prices of transactions, including farm buildings, were higher only during the last two years than the prices of supplementary arable land without farm buildings. Nonetheless, the real prices of transactions, including other buildings, exceeded in every year the prices of supplementary arable land without buildings.

A general picture of the price level of arable land can be seen in table 30 which presents appraised weighted average prices by Agricultural Advisory Centers during the period 1984-1986. Except for Finska Hushållningssällskapet, arable land transactions in different areas have been so numerous that the average prices in each area can be considered as reliable indicators of the price level.

Table 30 indicates that during the period 1984-1986, arable land price has been clearly highest (41 600 - 42 400 FIM) in Satakunta and Varsinais-Suomi. In these centers the price was $30 \%$ higher than the average level in southern Finland. Also in the Häme area, the price level was higher than the average level in the research region as a whole. The fourth highest price level was observed in the Finnish- and Swedish-speaking areas of Uusi-

Table 29. Weighted average price of transactions including buildings (FIM/ha) during 1982-1986a .

\begin{tabular}{lccccc}
\hline Year & $\begin{array}{c}\text { No } \\
\text { buildings }\end{array}$ & \multicolumn{3}{c}{ Including buildings } \\
\cline { 3 - 6 } & & Dwellings & $\begin{array}{l}\text { Dwellings } \\
\text { and farm } \\
\text { buildings }\end{array}$ & $\begin{array}{c}\text { Farm } \\
\text { buildings }\end{array}$ & $\begin{array}{c}\text { Other } \\
\text { buildings }\end{array}$ \\
\hline 1982 & 25240 & 24326 & 22814 & 24875 & 27907 \\
1983 & 27692 & & 37193 & 21149 & 31815 \\
1984 & 31641 & 114307 & 55817 & 31922 & 39532 \\
1985 & 33004 & & 59915 & 33648 & 36246 \\
1986 & 31920 & & 38792 & 3838 \\
\hline
\end{tabular}

Notes :

a Prices are deflated to the 1986 level by the cost-of-living index. 
Table 30. Prices of arable land (FIM/ha) in transactions of supplementary arable land without buildings during the period 1984-1986, by Agricultural Advisory Centersa.

\begin{tabular}{lccc}
\hline $\begin{array}{l}\text { Agr. Adv. } \\
\text { Center }\end{array}$ & $\begin{array}{c}\text { Number } \\
\text { of trans- } \\
\text { actions }\end{array}$ & $\begin{array}{c}\text { Weighted } \\
\text { average } \\
\text { price }\end{array}$ & $\begin{array}{c}\text { Relative price } \\
\text { of arable land } \\
\text { (Southern } \\
\text { Finland }=100 \text { ) }\end{array}$ \\
\hline Uusimaa & 68 & 28832 & 89 \\
Nylands Svenska & 36 & 29706 & 92 \\
Varsinais-Suomi & 127 & 41592 & 129 \\
Finska Hushállningss. & 4 & 25369 & 79 \\
Satakunta & 116 & 42376 & 131 \\
Pirkanmaa & 48 & 20243 & 63 \\
Häme & 90 & 22746 & -105 \\
Itä-Häme & 31 & 24767 & 68 \\
Kymenlaakso & 64 & 19381 & 77 \\
Etelä-Karjala & 50 & 32238 & 60 \\
\hline Southern Finland & 634 & 100 \\
\hline
\end{tabular}

Notes:

a Prices are deflated to the 1986 level by the cost-of-living index.

maa, where the weighted price of arable land remained $10 \%$ lower than the average level in southern Finland.

The prices of transactions of supplementary arable land were lowest in Pirkanmaa, ItäHäme, Kymenlaakso, and Etelä-Karjala. In these centers, prices were about a third lower than the average level.

\subsubsection{The price of supplementary arable land and its development according to purchases of arable land by the National Board of Agriculture}

In purchases by the National Board of Agriculture the appraisal of arable land is based on the local general price level of free

Table 31. Price of arable land (FIM/ha) in the purchases of the National Board of Agriculture in southern Finland, 1972-1986.

\begin{tabular}{|c|c|c|c|c|c|}
\hline \multirow[t]{2}{*}{ Year } & \multicolumn{2}{|c|}{ All transactions } & \multicolumn{3}{|c|}{ Quality classes of arable land } \\
\hline & $\begin{array}{c}\text { Average } \\
\text { price }\end{array}$ & $\begin{array}{c}\text { Change from } \\
\text { preceding } \\
\text { year } \%\end{array}$ & I class & II class & III class \\
\hline 1972 & 3127 & & 3830 & 2866 & 1985 \\
\hline 1973 & 4811 & +53.9 & 5136 & 4631 & 3788 \\
\hline 1974 & 5516 & +14.7 & 5906 & 4971 & 3989 \\
\hline 1975 & 5694 & +3.2 & 6657 & 5036 & 3739 \\
\hline 1976 & 6575 & +15.5 & 7724 & 6027 & 4413 \\
\hline \multirow[t]{2}{*}{1977} & 8129 & +23.6 & 9323 & 7564 & 6153 \\
\hline & & & \multicolumn{3}{|c|}{ Subsurface drained Open drainage } \\
\hline 1978 & 8973 & +10.4 & \multicolumn{2}{|c|}{11298} & 8252 \\
\hline 1979 & 10091 & +12.5 & \multicolumn{2}{|c|}{12952} & 8907 \\
\hline 1980 & 9236 & +8.5 & \multicolumn{2}{|c|}{12715} & 8730 \\
\hline 1981 & 11912 & +29.0 & \multicolumn{2}{|c|}{15088} & 9993 \\
\hline 1982 & 13655 & +14.6 & \multicolumn{2}{|c|}{17777} & 11206 \\
\hline 1983 & 13557 & -0.7 & \multicolumn{2}{|c|}{17893} & 11185 \\
\hline 1984 & 15968 & +17.8 & \multicolumn{2}{|c|}{19067} & 13686 \\
\hline 1985 & 15315 & -4.1 & \multicolumn{2}{|c|}{$23 \quad 224$} & 13991 \\
\hline 1986 & 22993 & +50.1 & \multicolumn{2}{|c|}{25642} & 17826 \\
\hline
\end{tabular}


market transactions. Appraising the arable land price by the local current price means that appraisals are based on the price level of transactions of supplementary arable land.

Thus, the National Board of Agriculture is excercising extreme caution with respect to the pricing of purchases. It has the policy that pricing must not be the cause of a rise in the price of land. Those prices are not considered which result from price competition between different buyer groups. The average prices of the purchases of the National Board of Agriculture, weighted by area, are given in table 31.

In the purchases of the National Board of Agriculture, from 1972 to 1986, the price of arable land has risen 7.4-fold. The average price rise of arable land in purchases was $15.3 \%$ a year. The price difference between subsurface drained and open drained arable land developed in the following way during the research period:

$\begin{array}{llcl}1978 & 3046 \text { ha/FIM } & 37 \% \\ 1979 & 4045 & ” & 45 \% \\ 1980 & 3985 & " & 46 \% \\ 1981 & 5095 & " & 51 \% \\ 1982 & 6571 & " & 58 \% \\ 1983 & 6708 & " & 60 \% \\ 1984 & 5381 & " & 39 \% \\ 1985 & 9233 & " & 66 \% \\ 1986 & 7816 & " & 44 \% .\end{array}$

In 1978, subsurface drained arable land cost $37 \%$ more and in 1983, $60 \%$ more than open drained arable land. In 1984 the difference was less, but increased again during the last two years investigated to a level that almost corresponded to the drainage cost per hectare.

If the prices paid annually by the National Board of Agriculture for arable land are transformed to 1986 prices, the real price development of arable land can be determined (appendix 7, table 7.1). The table shows that the price of arable land was the highest in 1973, 1979, 1982, 1984, and 1986. During the latter

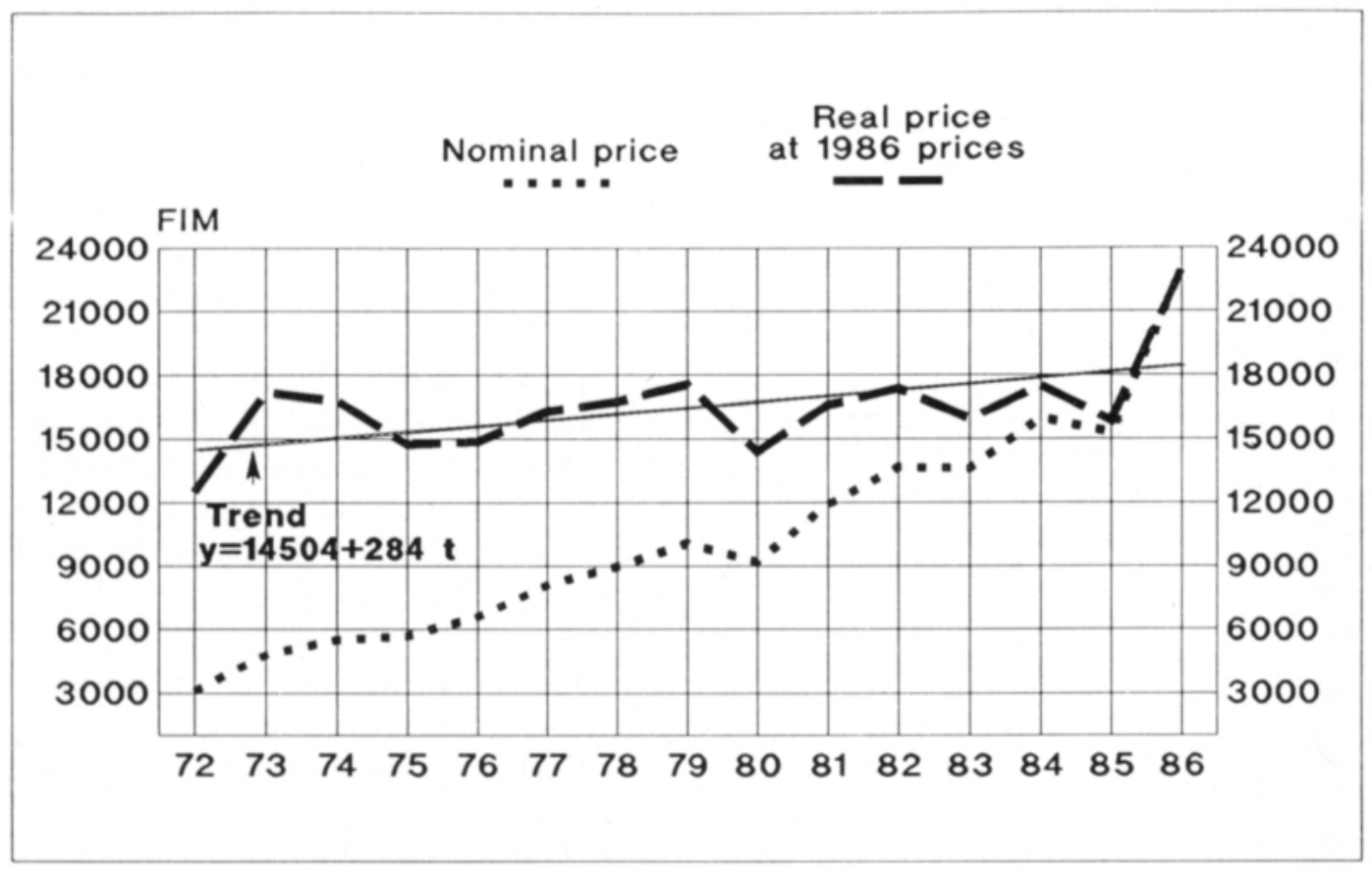

Figure 14. The development of nominal and real prices of arable land (FIM/ha) and the real price trend, 1972-1986, according to the purchases by the National Board of Agriculture. 
year, the price of arable land was exceptionally high, i.e. about $40 \%$ higher than the 1980-1985 level. The real price of arable land, as a three year mean for the last three investigated years (1984-1986), was 18800 FIM/ha. All in all, the real price of arable land in the purchases of the National Board of Agriculture, despite rather large annual variations, has undergone only a slight increase (figure 14).

The trend line in figure 14 is estimated from the following model:

$$
\begin{aligned}
\mathrm{y}= & 14504+284 \mathrm{t}, \text { where } \mathrm{t}=0 \ldots 14 \text { (years } \\
& 1972-1986) .
\end{aligned}
$$

The yearly change was on an average $1.7 \%$, calculated as compound interest.

In the pricing of arable land purchased by the National Board of Agriculture, the average value (above), weighted by area, has been used along with data from the market price register. If the arable land purchased by the National Board of Agriculture was representative with respect to the proportion of subsurface drainage, approximately $50 \%$ in southern Finland (ANON. 1980 b), the price level it paid for arable land rises closer to the general price level (when appraisals are made by the arithmetical average value of subsurface or open drained arable land).

Table 32. The average value of prices of subsurface and open drained arable land in the purchases of the National Board of Agriculture, 19781986a.

\begin{tabular}{lc}
\hline Year & Price level of arable land (FIM/ha) \\
\hline 1978 & 9775 \\
1979 & 10930 \\
1980 & 10723 \\
1981 & 12541 \\
1982 & 12492 \\
1983 & 14539 \\
1984 & 16377 \\
1985 & 18608 \\
1986 & 21734 \\
\hline
\end{tabular}

a The percentage of subsurface drained arable land for free sale does not correspond to the subsurface drained percentage of the cultivated arable land as a whole (compare Ala-KantTI 1981, p. 38).
The results in table 32 indicate that the price level examined in this way was, except in 1986, higher than the price level shown in table 31 . At the same time, annual price changes are smaller than when using the weighted average price, because in the figures of table 32 , the ratio between subsurface and open drained arable land prices remains constant.

\subsubsection{Price differences between transactions of supplementary arable land in the market price register and the purchases of arable land by the National Board of Agriculture}

Transactions of arable land under cultivation (without buildings) in the period 19821986 , derived from the statistics of the National Board of Land Surveying, primarily describe the prices paid for land by farmers. On the other hand, the market price register also includes transactions, by the National Board of Agriculture, concerning supplementary arable land (including arable land under cultivation). Thus, the price information of the register does not entirely represent the price level on the free market. In addition, transactions between farmers also include transactions financed with loans in accordance with the Farm Act.

In transactions of supplementary arable land without buildings, the area-weighted average price in southern Finland has been determined using both nominal and real prices. By comparing arable land prices paid $b$ the National Board of Agriculture, with info mation given by the market price register, the general relationship between these two price statistics and price development can be found (table 33).

Table 33 shows that the price level in the purchases of arable land by the National Board of Agriculture is clearly lower than the price level in the market price register. Arable land purchases by the National Board of Agriculture have varied on a yearly basis from $48 \%$ to $72 \%$ of the prices in the market price register. The price ratio was the lowest $(0.48)$ 
in 1985, when the purchases of arable land by the National Board of Agriculture remained relatively insignificant, as well as being weighted towards open drained land. The correspondence between market prices was the highest during 1986 when about two thirds of the land purchases of the National Board of Agriculture concerned subsurface drained arable land, while during the preceding years the arable land purchased by the National Board of Agriculture mainly concerned open drained arable land. The average price level of the purchases of the National Board of Agriculture represented $60 \%$ of the level of the market price register during the period 1982-1986.

Table 33. A comparison of the price of arable land (FIM/ha) according to the National Board of Land Surveying (NBLS) and the National Board of Agriculture (NBA), for the period $1982-1986$ in the investigated region.

\begin{tabular}{lccc}
\hline Year & $\begin{array}{c}\text { Transactions of } \\
\text { supplementary } \\
\text { arable land by } \\
\text { NBLS }\end{array}$ & $\begin{array}{c}\text { Purchases } \\
\text { by NBA }\end{array}$ & $\begin{array}{c}\text { NBA/ } \\
\text { NBLS }\end{array}$ \\
\hline 1982 & 19872 & 13655 & 0.69 \\
1983 & 23636 & 13557 & 0.57 \\
1984 & 28850 & 15968 & 0.55 \\
1985 & 31823 & 15315 & 0.48 \\
1986 & 31926 & 22993 & 0.72 \\
\hline Average & & & 0.60 \\
\hline
\end{tabular}

It would seem that the differences related to the quality and location of arable land have had an effect on the rather considerable differences between the market price register (NBLS) and the National Board of Agriculture concerning the annual market prices. A more detailed examination of these effects would have required complementary information and was not possible within the framework of this investigation.

Comparisons in different regions between arable land prices paid by the National Board of Agriculture and price information from the market price register are impeded by the $\mathrm{Na}$ tional Board of Agriculture's small number of transactions. To improve the situation, a price comparison is made by using three year moving averages; the total number of purchases amounting to 106 during the three years. First, the prices of 1984 and 1985 are converted to the 1986 price level. The average value, weighted by the area of purchases of arable land by the National Board of Agriculture, was then assessed at $19555 \mathrm{FIM} / \mathrm{ha}$, which is about 12700 FIM lower than the arable land price appraised in a corresponding way from the market price register. There are also rather large regional variations in the price level (table 34).

Table 34. Regional variations in the price of arable land (FIM/ha) appraised according to data from the market price register (NBLS) and the National Board of Agriculture (NBA), 1984-1986, at 1986 prices.

\begin{tabular}{lccc}
\hline $\begin{array}{l}\text { Agr. Adv. } \\
\text { Center }\end{array}$ & $\begin{array}{c}\text { Transactions of } \\
\text { supplementary } \\
\text { arable land by } \\
\text { NBLS }\end{array}$ & $\begin{array}{c}\text { Purchases by } \\
\text { NBA }\end{array}$ & NBA/NBLS \\
\hline Uusimaa & 28832 & 19134 & 0.66 \\
Nylands Svenska & 29706 & 16431 & 0.55 \\
Varsinais-Suomi & 41592 & 20197 & 0.49 \\
Finska Hushállningss. & 25369 & 22908 & 0.90 \\
Satakunta & 42376 & 16781 & 0.40 \\
Pirkanmaa & 20243 & 19854 & 0.98 \\
Hăme & 33746 & 24679 & 0.73 \\
Itä-Häme & 22028 & 14032 & 0.64 \\
Kymenlaakso & 24767 & 20870 & 0.84 \\
Etelä-Karjala & 19381 & 15972 & 0.82 \\
\hline Southern Finland & 32238 & 19555 & 0.61 \\
\hline
\end{tabular}


Thus, in transactions for supplementary arable land, the National Board of Agriculture paid approximately $61 \%$ of the price paid in transactions in the market price register, with a regional variation of $40 \%$ to $98 \%$. It is worth noting that the relative prices paid by the National Board of Agriculture were particularly low in Varsinais-Suomi and Satakunta, where the price level of transactions of supplementary arable land in the market price register were the highest.

Besides the small number of arable land transactions by the National Board of Agriculture, price differences were mostly influenced by the lack of competition in the purchases of the National Board of Agriculture. In addition, it is commonly believed that the purchases of the National Board of Agriculture concern remotely located arable land and land otherwise of low market value. 


\section{COMPARISON BETWEEN}

\section{CAPITALIZED VALUE AND}

MARKET PRICES OF

SUPPLEMENTARY ARABLE LAND

The comparison between capitalized value and market prices can only be an approximation. It is clear that productive and economic conditions on individual farms may vary considerably. The comparisons that will be presented cannot therefore be generalized for all farms. Similarly, factors related to production structures, or types of farms, and the size of arable lands, prevent the generalization of the results. Capitalized value is defined above only for two typs of farms, cattle farms specialized in dairying and grain farms.

In the appraisal of the capitalized value of supplementary arable land, the final results depend on, in addition to the importance of return, its duration and the capitalization rate employed. Consequently, appraisals were made using three different interest rates and durations. The marginal tax rate was also taken into consideration for the determination of the net marginal operating margin that is to be capitalized on the basis of the results of the regression models. For cattle farms a marginal tax rate of $40 \%$ was selected, and $50 \%$ for grain farms.
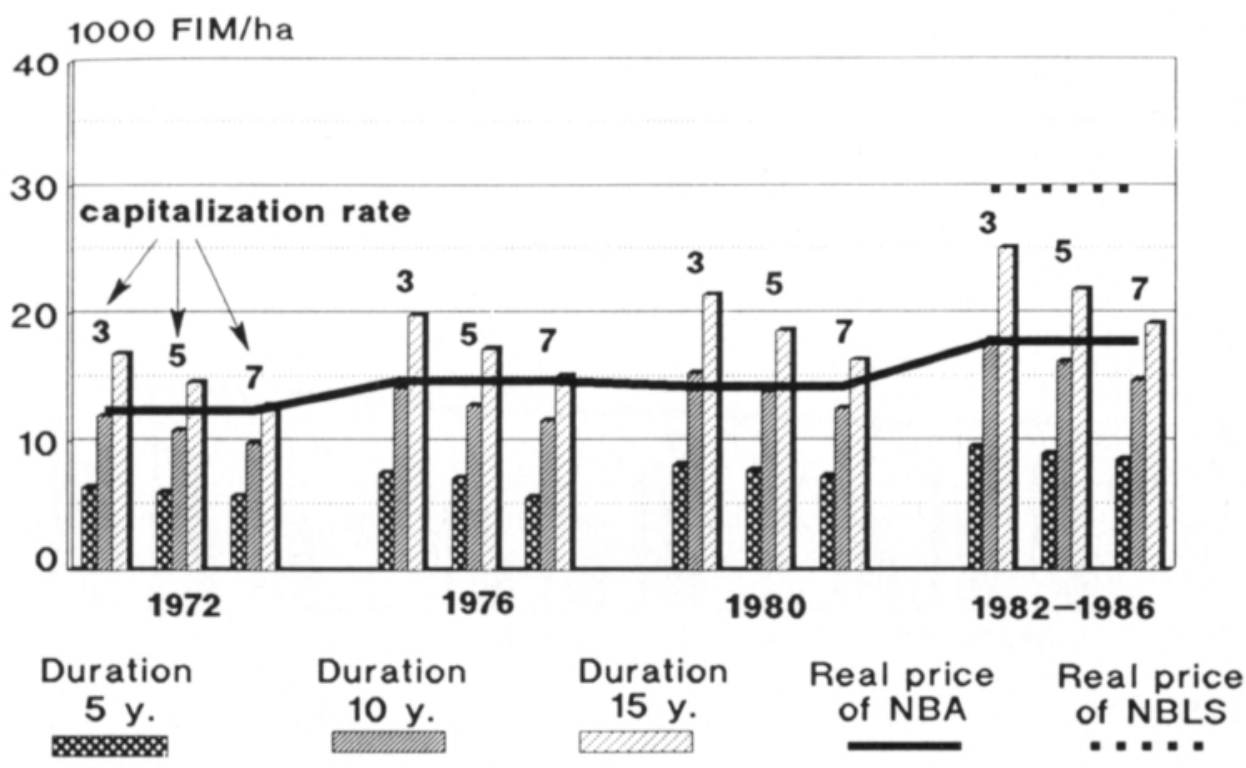

Figure 15. Comparison between the capitalized value of supplementary arable land and market prices on cattle farms, at 1986 prices. 
Market prices for supplementary arable land are based on the prices of arable land purchased by the National Board of Agriculture during the period 1972-1986, as well as market price statistics of the National Board of Land Surveying from 1982 to 1986 . The level of the capitalized value and market prices are described in figure 15 .

In figure 15 , the columns for each year describe present values capitalized at interest rates of $3 \%, 5 \%$, and $7 \%$ for different durations. The results indicate a continuous increase of the capitalized value of the arable land on cattle farms during the research period. In general, when the returns from supplementary arable land were capitalized for a period of 15 years, the capitalized value of supplementary arable land on cattle farms increased at least to the price of arable land paid by the National Board of Agriculture. The capitalized value determined for ten years did not reach the price level paid by the National Board of Agriculture during all the years investigated. Further, a duration of five years proved too short for the capitalized value to rise to the market price level in any of the years investigated.

The capitalized value of supplementary arable land, determined for the period 19821986 (which describes the value of arable land in the most reliable way, rather than for separate years), exceeded the price paid for arable land by the National Board of Agriculture when appraised at each interest rate and for a duration of 15 years. On the other hand, when an interest rate of $5 \%$ and a duration of 10 years were used for capitalization, the capitalized value did not reach the market price level. On the basis of these comparisons, it may be noted that the relationship between the capitalized value of supplementary arable land on cattle farms, and the price of land paid by the National Board of Agriculture, has remained almost unchanged during the years investigated. On the other hand, the price according to the market price register of the National Board of Land Surveying, almost $30000 \mathrm{FIM} / \mathrm{ha}$, proved to be clearly higher than the capitalized value of supplementary arable land.

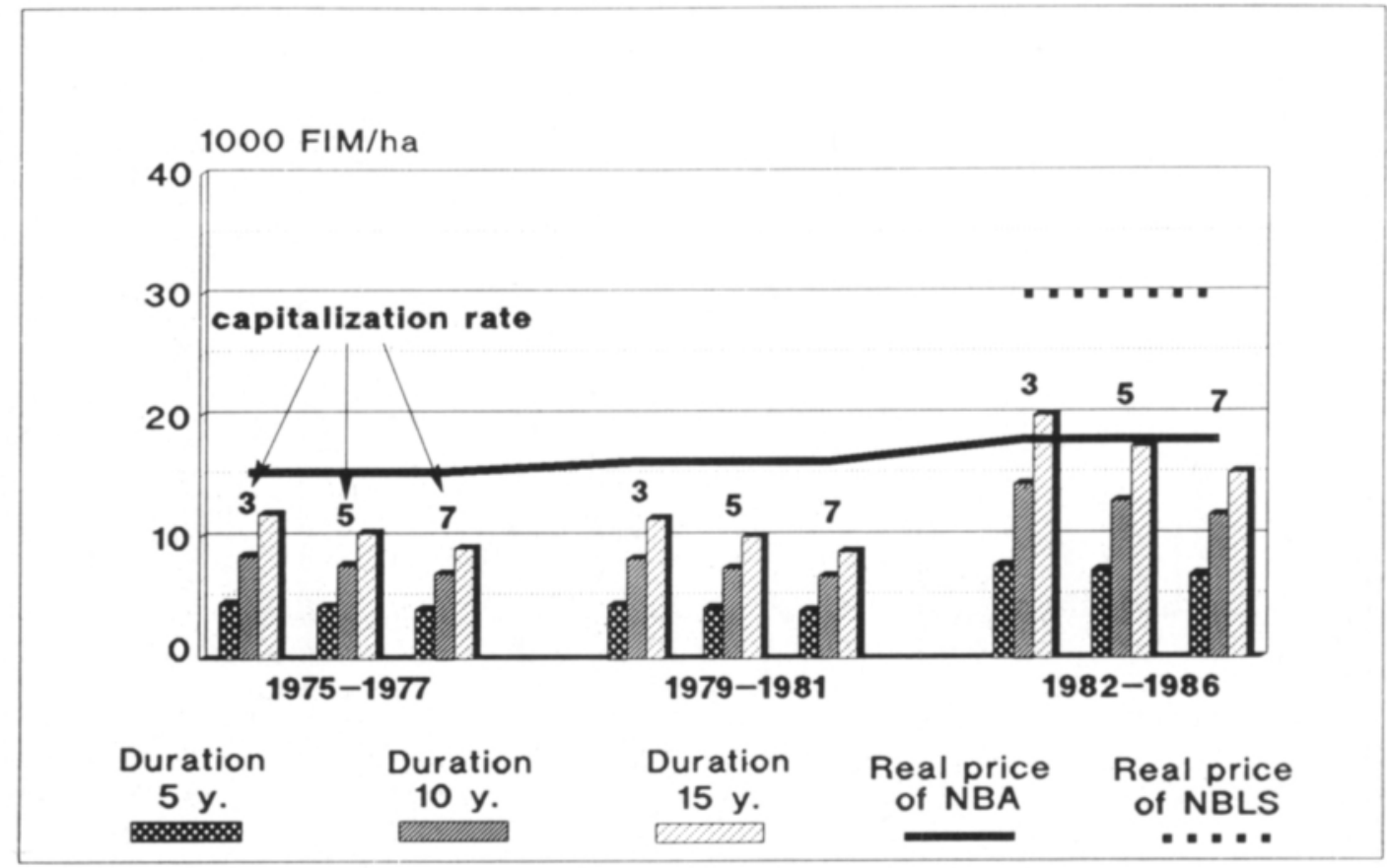

Figure 16. Comparison between capitalized value and market prices of supplementary arable land on grain farms, at 1986 prices. 
The correspondence between the capitalized value and market prices of supplementary arable land on grain farms is presented in figure 16. The return from supplementary arable land on grain farms was assessed for three consecutive years to avoid yield variation problems, but excluding the last period of examination. Farms that had maintained the same production structure during the three or five year periods were accepted for consideration. Because the capitalized values of arable land on grain farms remained generally lower than for cattle farms, they reached the level of prices paid by the National Board of Agriculture only during 1982-1986 when using a capitalization rate of $3 \%$ and a duration of 15 years. During all other investigated periods, the capitalized value of supplementary arable land on grain farms remained lower than the market prices of the National Board of Agriculture and still lower than the market prices of the National Board of Land Surveying. 


\section{RESULTS AND CONCLUSIONS}

\subsection{Return from supplementary arable land}

Returns from supplementary arable land have been determined, for given periods, for cattle and grain farms using the Cobb-Douglas production functions. The farms considered were those which had practiced continuous bookkeeping since 1968. During this period, the current tax system in agriculture has been in force. The results of the study are based on both cross sectional and time series data.

In both farm types examined, production functions analyses showed an obvious increase in return from supplementary arable land as a function of time. After dummy variables (fu/ha) were added to the regression model, the effect of yield level on return from supplementary arable land was assessed. Especially, the marginal value product on grain farms proved, according to expectations, sensible to variations in yield level. On the other hand, on cattle farms, yield levels had a smaller effect on the return from supplementary arable land. This is understandable, because during rainy summers, crop yields may remain low, while pasture and grass yields increase with no notable deterioration in quality.

The results of cattle farms for the years 1972, 1976, and 1980 are based on the use of cross sectional data for those years. However, because of the rather large annual variation in yields on grain farms, the determination of their marginal value product demanded the use of three-year means. Therefore, the return from supplementary arable land on grain farms was estimated for the periods 19751977 and 1979-1981. Thus, the return from supplementary arable land in both farm groups could be reliably determined only for the last reseach period, 1982-1986. Only farms that had continuously maintained the same production structure during the research period were accepted for analysis. The effect of the yield level variable describing the quality of arable land on the marginal value product from arable land during 1982 - 1986 is shown in table 35 .

Table 35. The effect of the yield level variable.

\begin{tabular}{lcc}
\hline & $\begin{array}{c}\text { Marginal value } \\
\text { product } \\
\text { (FIM/ha) }\end{array}$ & Yield (fu/ha) \\
\hline Cattle farms & 4013 & $<2500$ \\
& 4147 & $2500-3300$ \\
Grain farms & 4294 & $>3300$ \\
& 4089 & $<2500$ \\
& 4919 & $2500-3300$ \\
& 5512 & $>3300$ \\
\hline
\end{tabular}

The average feed unit yield ( $\mathrm{fu} / \mathrm{ha}$ ) in both farm types was $2500-3300 \mathrm{fu} /$ ha during the period concerned. The variation in arable land quality on cattle farms, measured by yield level, appeared to be smaller than on grain farms. With an increase in yield level, the marginal value product also increased in both farm groups. Consequently, the use of the yield level dummy variable to describe the quality of agricultural land proved a viable solution. The solution had, in fact, been successfully applied previously, e.g. by LOCKEN et al. (1978). In addition, the results given by the present investigation regarding the return from supplementary arable land receive support from the results of ELSTRAND (1980). Elstrand applied production functions to the analysis of the importance of land rent on 
Norwegian dairy and grain farms. Cross-sectional data were used concerning Norwegian bookkeeping farms. For these two farm types, the return from supplementary arable land on grain farms also showed itself to be higher than on dairy farms.

The estimation of the return from supplementary arable land has been based on the use of a production function explaining gross return in agriculture. Therefore, the marginal value product from supplementary arable land, assessed by parameter estimates, describes the growth in gross return in agriculture when the arable land area is increased by one hectare. The farmer is unable to use the additional gross return exclusively for the acquisition of supplementary arable land, but variable costs derived from cultivating the supplementary land must be subtracted. As a result, those variable costs that were not included as independent variables in the regression models, were subtracted from the marginal value product of supplementary arable land. The operating margin assessed in this way does not, by definition, absolutely correspond to the concept of operating margin, which represents a compensation for the fixed production factors of the farm. The operating margin so determined indicates the compensation per hectare that remains for arable land acquisition before taxation.

In practice, arable land acquisition is financed either in totality or partially by taxable income. Therefore, taxes were subtracted from the marginal operating margin. In the determination of taxes, reference was made to Sirrola (1988, p. 55-58). On this basis, the marginal tax rate, due to additional income in agriculture, was set at $40 \%$ for cattle farms and $50 \%$ for grain farms. The marginal tax rates were selected because the investigated bookkeeping farms can be considered to be rationally managed and practicing intensive production, i.e. they have participated in bookkeeping activities for a long period of time.

The dependency between the marginal value product from arable land and the size of farm is of interest. The benefit gained from supplementary arable land is supposed, following theory, to be the highest in the smaller farm size classes. This contention was investigated by dividing the research data into two size classes. By using production function analysis, the marginal value product from supplementary arable land on cattle farms of less than 25 ha, determined for the period 19821986, varied from 4775 FIM to almost 5200 FIM. On larger farms, the marginal value product was no more than $1360-1700$ FIM. The results, therefore, supported the expectations, and indicated that economic results on cattle farms in the larger size class are probably more dependent on other production inputs and their utilization than on supplementary arable land.

On the other hand, on grain farms, the addition of arable land seemed to favour the larger farm size class. On farms of less than 30 hectares, the marginal value product from supplementary arable land per hectare varied from 3400 to 4500 FIM, while the variation in larger farms was between 4300 and 5400 FIM. The different development of marginal value product from supplementary arable land between the farm types results because rather small grain farms are, to a large extent, a secondary occupation for the farmer. Further, grain farms have more machinery, with their attendant costs, compared to cattle farms, and unit costs decrease along with an increase in the area of arable land. Moreover, the years 1982-1986 were characterized by good weather conditions and satisfactory yield levels. Thus, an increase in arable land area on rather large grain farms proved economically justified within the framework of the production technology employed.

The analysis of the differential return, calculated on the basis of the taxable net return in agriculture, also supported the different development of the return from supplementary arable land as a function of farm size with respect to both cattle and grain farms. The analysis was based on the method presented by Elstrand (1980), which showed that the 
differential return from supplementary arable land was largest (4 $769 \mathrm{FIM} / \mathrm{ha}$ ) when moving from the smallest size-class of cattle farms, less than 20 ha, to a larger class. As for grain farms, the greatest increase in differential return (4023 FIM/ha) was realized when moving from the $20-30$ ha class to the $30-50$ ha class. It is worth noting that the differential return, remaining as interest on capital invested in agriculture on farms of 30 ha or larger, was still higher than the average taxable net return for the farm groups in question.

\subsection{Market prices of supplementary arable land}

Two different price statistics were used when price information on arable land was collected: the market price register of real estates of the National Board of Land Surveying, and the statistics on land acquisitions of the National Board of Agriculture. From the former statistics, only information concerning the years 1982 - 1986 was available, while the arable land acquisitions of the $\mathrm{Na}$ tional Board of Agriculture have been recorded since the 1960's. The market price register also includes the land acquisitions by the National Board of Agriculture, as well as transactions on supplementary arable land financed according to the Farm Act (arable land areas of more than 2 ha). The characteristics of both price statistics have been examined in more detail in section 5.1.

The price development of arabie land in southern Finland can be determined for the period beginning in the early 1970's only by using the price statistics on transactions on supplementary arable land by the National Board of Agriculture (figure 14) This indicates a considerable rise in nom: ial prices, but it is rather moderate in real terms.

The price development of supplementary arable land in land acquisitions of the $\mathrm{Na}$ tional Board of Agriculture therefore diverges considerably from the price development in Sweden, Denmark, Holland, or France. In these countries, the real rise in land prices was rapid during the final years of the 1970's (ANDERSSON 1989, p. 1-4). ANDERSSON (1989 p. $88-89$ ) considered that the main reason for the rise of land prices in Sweden was the low real interest rate prevailing during that period and the simultaneous price rise of agricultural products on the world markets. The downturn in the trend of land price in the 1980's was connected with the decrease in prices of agricultural products. This would mean that Swedish agricultural protectionism did not completely guarantee profitability in an agricultural sector that was facing price effects from international markets.

Comparisons show that the price level of arable land in acquisitions by the National Board of Agriculture was c. $60 \%$ of the prices recorded in the market price register. The majority of additional land is acquired, in practice, by transactions between farmers, and financed by the National Board of Agriculture. Thus, the statistics on loans involved in purchases of supplementary arable land would have been, in principle, a useful source material for price comparisons of arable land.

During the period 1982-1983, in transactions in accordance with the loan statistics, the price of arable land was even higher than prices recorded by the market price register. The price development during these years suggests that loans granted for the purchase of additional land contributed to the increase in the price of arable land. A more probable interpretation might be that the loan-related price statistics include agricultural properties (not just land), the price effect of which is reflected in price per hectare. Therefore, because of the duration of the investigated period and the unambiguous interpretation of the price statistics, the price statistics representing purchases of arable land by the National Board of Agriculture were chosen for the study and not the loan statistics.

The market prices of supplementary arable land in Finland can be explained by factors endogenous to agriculture (LAURILA 1988). These endogenous factors (market activity, 
profitability in agriculture, quality of arable land, and yield level) explained $63 \%$ of the variation of arable land prices. After an external factor (employment) was integrated in the price model, the degree of determination of the model increased only by 4 percentage points. In this respect, the situation differs considerably from the price development of agricultural land in the United States, where CASTle and Hoch (1982) have shown that capital gains explain half of the increase in land prices. Even though expectation values near large population centers in southern Finland have had some impact on the prices paid for land, the significance of such land acquisition on the agricultural land prices seems to be rather doubtful.

\subsection{Correspondence between the capitalized and market values}

Capitalized value depends on both the interest rate used for capitalization and the duration of the return. In this study, the capitalization of return was realized at $3 \%, 5 \%$, and $7 \%$ interest rates while the corresponding durations were 5,10 , and 15 years. The depreciable agricultural property items were adjusted to correspond better with real market value (appendix 1). If bookkeeping values for property had been used, the value of depreciable property items would have decreased from 1968 to 1986 , even though investments were, on average, higher than tax depreciations (compare LatUKKa 1989, p. 81-82). Thus, the depreciable property, adjusted by the cost-of-living index, on cattle and grain farms, clearly increased. In fact, it doubled in 1986 compared to the taxable depreciable property items. Yet, according to KUKKONEN (1990), a real interest of $5 \%$ or $7 \%$ may be considered to be quite high because, the level of real interest in the long term should follow the annual growth percentage of the gross national product.

The results of the study by the Farmers' Social Insurance Institution were taken into consideration when selecting the duration of the return for the assessment of capitalized value. Within the framework of the Farm Closure Pension Act and those farmers continuing agriculture, following generation transfers, the mean age of farmers who had acquired supplementary arable land was found to be 44 years (TolONEN 1985, p. 17). In addition, with respect to loans via the Farm Act, the amortization period of loans for acquisition of supplementary arable land proved to be relatively short, mainly five to eighteen years in southern Finland. On the other hand, the social time preference for the capitalization of return is essentially longer than the individual time preference. In this case, returns are supposed to continue infinitely.

Comparisons between capitalized and market values showed that the capitalized value of supplementary arable land on cattle farms, during the whole period investigated, attained the market price paid by the National Board of Agriculture when the duration of return was 15 years. When a duration of return of 10 years was employed, the capitalized value of land no longer reached the price paid by the National Board of Agriculture in all periods during the investigated years. The results for cattle farms are shown in figure 17.

Each set of three columns in figure 17 represents a single time period or year and the column on the left of each triad describes the case in which the net marginal operating margin of supplementary arable land is capitalized at $3 \%$ interest. The darkest part of the column describes a capitalized present value for a duration of 5 years to which have been added the cumulative difference of capitalized present values between 10 and 5 years, and between 15 and 10 years. The height of the column indicates the capitalized present value for a duration of 15 years, at an interest rate of $3 \%$. Correspondingly, the middlemost column describes the cumulative present value at $5 \%$ and the one on the right at $7 \%$ interest.

On the other hand, the present value on grain farms (figure 18) has remained clearly lower than the market prices paid by the $\mathrm{Na}$ tional Board of Agriculture, except during the 


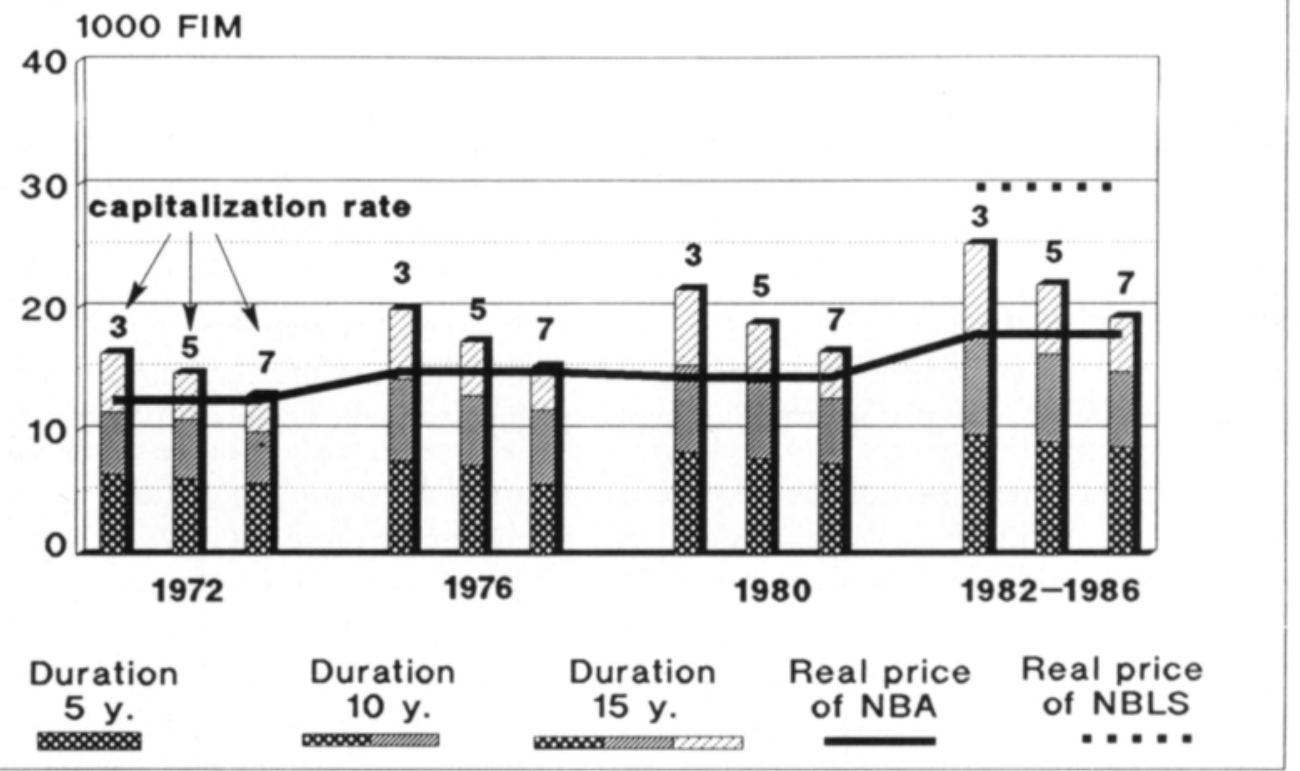

Figure 17. Cumulative capitalized value (FIM/ha) of arable land on cattle farms and the price of arable land in purchases by the National Board of Agriculture, at 1986 prices.

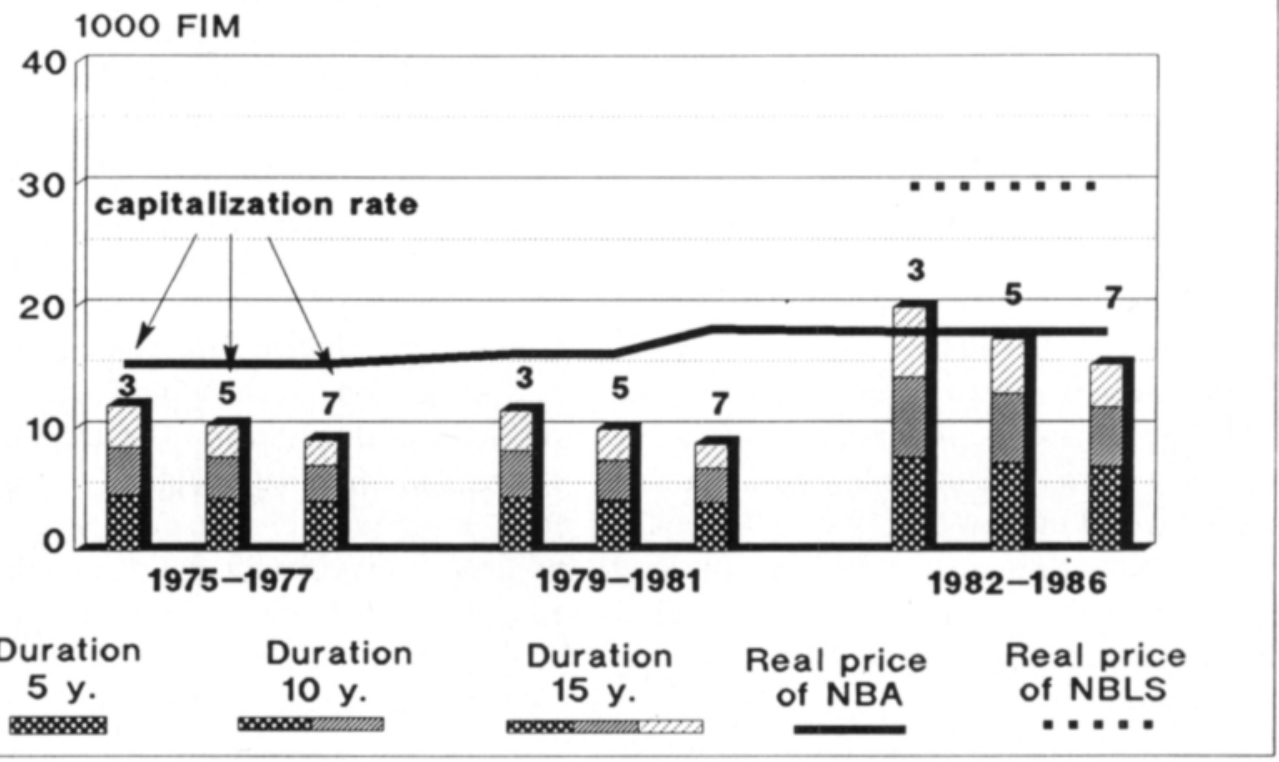

Figure 18. Cumulative capitalized value (FIM/ha) of arable land on grain farms and price of arable land in purchases by the National Board of Agriculture, at 1986 prices. 
period 1982 - 1986. Only during this latter period did the present value on grain farms reach the level of market prices paid by the National Board of Agriculture.

Yield level has only a small effect on the capitalized value of cattle farms. If the average feed unit yield during 1982-1986 was lower than $2500 \mathrm{fu} / \mathrm{ha}$, the capitalized value of arable land would decrease by little more than $3 \%$. If the quality of arable land, measured by yield level, exceeded the productivity of $3300 \mathrm{fu} / \mathrm{ha}$, the present value of supplementary arable land would be increased by $3.5 \%$, as may be observed in table 18 . On the other hand, the impact of yield level was obviously greater on grain farms than on cattle farms. If yield levels remain below the median class, the present value would decrease by almost $17 \%$. If the yield level per hectare exceeded $3300 \mathrm{fu}$, capitalized value would increase by approximately $12 \%$.

Consequently, the effects of variation in yield level were manifested quite differently in the farm types investigated. Nevertheless, the variation did not change the general picture concerning the capitalized value in the farm groups. On cattle farms, throughout the periods investigated, capitalized value reached the price level for arable land paid by the $\mathrm{Na}$ tional Board of Agriculture when the return was capitalized using all three capitalization rates based on a 15 year duration. On the other hand, the present value of supplementary arable land on grain farms reached the price level of purchases by the National Board of Agriculture only during the period 1982 - 1986, and when the capitalization rate was $3 \%$ and $5 \%$ for a duration of 15 years. During the earlier periods investigated, the present value of supplementary arable land on grain farms remained lower, even for the best land, than the prices paid by the National Board of Agriculture.

It should be noted that many other factors, besides return on the cultivation of arable land, have an influence on the level of market prices paid for arable land. These other factors may be changes in Finnish agricultural policy and the financial means of its implementation.

Because southern Finland has been chosen as the research region, the regional support scheme for agriculture is only weakly effective in the areas investigated. On the other hand, different voluntary agreements, as well as legislation, concerning changes in production aimed at decreasing livestock production, have somewhat restrained agricultural practices. The dual price system for milk, implemented in the beginning of 1985 , has been effective in controlling milk production, although its impact can be observed only during the two last years researched.

Thus, the conditions of neoclassical theory, requiring perfect competition are not fully realized in dairy farming. On grain farms these conditions are better realized, because production has not been so affected by agricultural policy means. Nonetheless, even on grain farms, the cultivation of special crops has long been based on contracts.

As for financial factors, real interest will be considered in more detail. Real interest rate was $4.5 \%$ negative during the period 19751977 , while for the period 1979-1981 real interest was only slightly negative, turning clearly positive $(3.2 \%)$ during the period 1982-1986. The turning point was 1982 and a continuous growth of real interest followed during the subsequent years. By 1986, a real interest of $5.4 \%$ had to be paid on loans granted by cooperative and savings banks (appendix 8, figure 8.1.).

Moreover, the price development of cash crops appeared less favourable than for animal products during the 1970's (appendix 8, table 8.1.). With crop yields also remaining low and quality poor, the 1970 's saw a decrease in profitability, and consequently, in capitalized value. Therefore, in both farm groups examined, but especially grain farms, there may have been some speculative demand for supplementary arable land, despite the low level of capitalized value. It was possible to pay a higher price for arable land than its capitalized value when the project was financed with 
external capital and the real interest for the loan was negative. Further, the expectations on return from agriculture, and the expected increase in the value of land near population centers, could have encouraged higher prices for supplementary arable land than that assessed on the basis of their productive value.

Since 1984 , the state has tried to stabilize the increase in land prices by changing the financial practices concerning land acquisitions by not issuing loans for land acquisition, if the market price exceeded the estimated current price. It is probable that landowners reacted to this “financing ceiling"'. It can therefore be supposed that in at least some of the arable land transactions not involving state loans, higher prices were knowingly paid than in transactions which qualified for financing, even though it meant losing the exemption from stamp duty. This supposition is supported by the fact that prices in transactions recorded in the market price register of the National Board of Land Surveying exceeded the prices of farm-loan financed transactions during the years investigated.

\subsection{Conclusions}

The capitalized value of supplementary arable land depends not only on the amount of return, but also on its duration and the interest rate used for capitalization. If the duration of return is assumed to be 100 years, capitalized value on cattle and grain farms during the period 1982-1986 would be as follows:

\begin{tabular}{cll} 
Capitalization rate \% & Cattle farms & Grain farms \\
\hline 3 & $66832 \mathrm{FIM} / \mathrm{ha}$ & $52865 \mathrm{FIM} / \mathrm{ha}$ \\
5 & $41979 \mathrm{FIM} / \mathrm{ha}$ & $33206 \mathrm{FIM} / \mathrm{ha}$ \\
7 & $30179 \mathrm{FIM} / \mathrm{ha}$ & $23872 \mathrm{FIM} / \mathrm{ha}$.
\end{tabular}

As may be observed from this, the capitalized value of supplementary arable land would reach the market value (c. $30000 \mathrm{FIM} / \mathrm{ha}$ ) recorded by the National Board of Land Surveying, except at the $7 \%$ capitalization rate on grain farms. Such a long period of time is not realistic for an individual farmer, even with the hypothesis of constant return and interest. Also, generation transfers in farming occur approximately every 30 years, and this led to the choice of shorter durations of return for the assessment of the present values of supplementary arable land, as was explained in more detail in section 4.6.2.

Problems that impede the determination of the capitalized value of supplementary arable land, and the use of the market prices paid for them, are related to the representiveness and properties of the statistical data. The empirical data in this study are based on information collected from different sources. Each statistical source has its special characteristics, as discussed earlier. Common to these sources are problems created when generalizing the results assessed with them. For example, the capitalized values of supplementary arable land assessed for the bookkeeping farms of southern Finland might be somewhat higher than the values of all other farms in the same region. This hypothesis is derived from SuoMELA (1958, p. 81-82), who estimated that gross return, production cost, and agricultural surplus on bookkeeping farms during the 1950's were approximately $20 \%$ higher than on other farms of more than two hectares of arable land in the country as a whole. Consequently, the capitalized values of supplementary arable land on cattle and grain farms as determined in this investigation may be considered to be about one fifth too high, and therefore primarily indicative.

The representativeness of the data on market prices partly involves the same problems encountered with the use of bookkeeping data, namely, the majority of annual transactions of agricultural land concerns the transfer of whole farms from parents to children as part of the normal generation transfer process. According to the Farm Register, purchases of arable land destined for supplementary arable land in southern Finland amounted to a little over $7300 \mathrm{ha}$ /year during the period 1982 - 1986. The market price register of the National Board of Land Surveying, the source of prices in this study, consisted of en- 
tries of only 1233 ha per year, on average, for the same period. Conversely, in the statistics on purchases of arable land by the National Board of Agriculture, the state only acquired c. $500 \mathrm{ha} /$ annum during the whole period of investigation, 1972-1986. These statistics are nonetheless considered to best describe the price of arable land in the research region.

The National Board of Land Surveying's information on supplementary arable land prices represents the highest and that of the National Board of Agriculture the lowest level of prices paid for arable land.

Previous studies concerning land value and price (chapter 3 ) focused on the determination of either capitalized value or market value, at the exclusion of each other. The investigation in hand has sought to determine both the capitalized value of supplementary arable land and its market value, thereby enabling mutual comparisons. The results have shown that the average capitalized value on cattle farms reached, on the average, the price level of purchases of arable land by the National Board of Agriculture, given the reservation that the results of bookkeeping farms were still about a fifth higher than in other farms in southern Finland. On the other hand, the average capitalized value on grain farms remained, af- ter the adjustment in level, clearly lower than the market prices paid by the National Board of Agriculture. The prices in accordance with the market price register of the National Board of Land Surveying therefore exceed even the highest capitalized value on cattle farms by 10000 FIM during 1982-1986, while the corresponding difference with respect to grain farms reached 14000 FIM.

Capitalized value and market prices are subject to variations, both regionally and between different types of farms. Consequently, the results presented in this study are not valid in other regions or for other types of farms. It must also be emphasized that the results of the study indicate the average capitalized value and the development and level of market values in southern Finland only in an indicative way. Deviations concerning individual farms may be considerable.

On the other hand, the state's agricultural policy and social actions may also have an impact on the determination of land value. The economic conditions prevailing in society at any given time are reflected or capitalized in land value. Decreasing prices of agricultural products or diminishing agricultural support both decrease land prices, while probably a freer land market would have the opposite effect. 


\section{SUMMARY}

The aim of the study was to determine the capitalized and market values of supplementary arable land in the bookkeeping regions of southern Finland during the period 19721986.

The starting point was an examination of appraisal methods and the assessment of their applicability to the task in hand. The value of arable land was considered to be determined exclusively by the return from its cultivation. Also, the prices paid for arable land were considered to describe the value of arable land acquired for cultivation purposes only, without taking into consideration questions of expectation value.

First, central concepts of value and price used in appraisals of arable land were examined, as well as their applicability for different purposes. According to the terminology accepted by the Association of Finnish Real Estate Valuers, present value means “"current value determined as the capital value of return assessed on the basis of present use or potential use'”. Correspondingly, market value means current value or current price determined on the basis of market prices. Supplementary arable land means arable land already acquired or to be acquired, which is used or to be used exclusively for agricultural production. These definitions were applied in this study.

In chapter 2, the central factors influencing the value and price of supplementary arable land were examined. First, the effect of the quality of arable land, as well as that of demand and supply, were examined. It was observed that the effect of measures related to cultivation techniques and economic measures affecting the economic result in agriculture received emphasis and, thus, had an impact on land value. Conversely, the significance of land quality has weakened over time.

The strong demand for supplementary arable land, in comparison to its weak supply, increased the price level of arable land, especially when related to technological developments in agriculture and the increased use of machines, which have enabled the management of large-sized farms. The gap between the prevailing size of farm and the size of farm employing modern technology proved to be considerable.

Previous investigations indicated that factors affecting agricultural production and its profitability are also reflected in land values. Consequently, the distinct effect on the price of supplementary arable land of each of the contributing factors is difficult to define, even though they could be divided into general, quality, and individual factors.

The third chapter examined former studies dealing with present value and market value, as well as the procedures applied. First, the fundamentals of the appraisal of capitalized value and its dependence on different factors were examined, following which, an approach based on land rent, which has had application in both economics and agricultural economics, was presented.

The most common method for appraising the value of supplementary arable land has been to assess the return of supplementary arable land as a residual when the costs of other factors and production inputs have been subtracted from the gross return. In this approach, a central problem is the differences in the use of inputs and the difficulties related to their pricing. This method results in low or 
even a negative return for land for small farms.

A third method of appraising the return of supplementary arable land employs an approach based on the theory of marginal productivity, in which production inputs receive compensation equal to their marginal value product.

The second part of chapter 3 (section 3.2.), examined investigations which have dealt with market value. Problems concerning the availability and validity of data on market prices were also discussed. Several price investigations on supplementary arable land have been made in Finland, but long time-series of prices are available only in national statistics concerning land acquisitions and from the price statistics of notaries. Consequently, former Finnish price investigations usually focused on the examination of market prices of a small area or locality during specific years.

The empirical part of this investigation concerned southern Finland, where the natural conditions for agriculture (soil and climate) are the most favorable. For the determination of the capitalized value of supplementary arable land, the records of bookkeeping farms were used as a starting point. These farms have continuously participated in the profitability survey in agriculture since 1968. The data finally employed consisted of only those cattle and grain farms which were based principally on the use of arable land.

Before estimation, the taxable values of the depreciable property items (machines, buildings, and land improvements) on the bookkeeping farms were adjusted by the cost-ofliving index to the price level of 1986. The choice of variables was mainly based on the use of correlation analyses and experiments. First, a linear, Cobb-Douglas function, and a transcendental function were tested. The Cobb-Douglas function was chosen for the assessment of the marginal value product of supplementary arable land. Estimations were made by using both cross section and time series analyses from the years 1972-1986. The marginal value product on cattle farms was determined for 1972, 1976, 1980, and the period 1982 - 1986. Due to the annual variations in the yields on grain farms, estimations were made on the basis of three- to five-year data: 1975-1977, 1979-1981, and 1982-1986. Only farms that had maintained the same production structure throughout the period were included in the data. The average marginal value product of supplementary arable land was estimated most accurately for the period 1982 - 1986 for both farm groups. Yield level dummies were used in regression models as indicators of the quality of arable land (table 16).

Next, such variable costs that were not included in the explaining variables were subtracted from the marginal value product of arable land on both cattle and grain farms. The marginal operating margin so assessed indicated the pre-tax compensation, in Finnish marks per hectare, available for arable land acquisition.

For the determination of the taxable part of the additional income consequent upon the acquisition of additional land, a marginal tax rate of $40 \%$ was chosen for cattle farms and $50 \%$ for grain farms. By multiplying the marginal operating margin by a coefficient (1-marginal tax rate), the net marginal operating margin per hectare of arable land could be derived for both farming types (table 18).

For the capitalization of the capitalized value of supplementary arable land $3 \%, 5 \%$, and $7 \%$ interest rates were used with corresponding durations of return of 5,10 , and 15 years. The capitalized values assessed in this way increased continuously with time on cattle farms. Conversely, the capitalized value remained very low on grain farms, except during the last part of the research period (table 23).

When the dependency between the marginal value product of arable land and the area of arable land was examined, farms of both types were classified into two size classes. The results indicated that the marginal value product of arable land on cattle farms of less 
than 25 hectares was approximately three times greater than for the larger farm group. On grain farms, the marginal value product of arable land continued to increase with increasing farm size. In addition, the evaluation of differential return, based on the average taxable net return, similarly showed that the return gained from supplementary arable land was highest in the smallest farm-size class in the case of cattle farms. On the other hand, on grain farms, the marginal value product of arable land and the differential return remained high as the size of the farm increased.

The market prices paid for supplementary arable land were collected from the statistics on land acquisitions of the National Board of Agriculture from 1972-1986 and from the market price register of the National Board of Land Surveying. The latter statistics only covered the period 1982-1986, during which the number of transactions amounted to approximately 1233 ha a year, while the acquisitions of the National Board of Agriculture amounted to only 505 ha per year. As a result, the annual purchases of arable land represented a little over one thousandth of the total 1.1 million hectares of arable land in the research region.

The average price, weighted by the area of supplementary arable land in the transactions of the National Board of Agriculture, increased considerably until 1985 , but decreased during the last year investigated, (prices deflated by the cost-of-living index to 1986 values):

$\begin{array}{ll}\frac{\text { Year }}{1982} & \frac{\text { FIM/ha }}{25240} \\ 1983 & 27692 \\ 1984 & 31641 \\ 1985 & 33004 \\ 1986 & 31920 .\end{array}$

The average price per hectare of supplementary arable land in the study region area was 29899 FIM during the investigated years. In 1986, the highest prices for arable land were paid in the Agricultural Advisory Centres of
Satakunta and Varsinais-Suomi, in which the price of arable land exceeded 43000 FIM per hectare. During other years, the prices of arable land in these areas were also the highest. The next highest price for arable land during the period 1982-1986 was observed in the area of the Agricultural Advisory Center of Häme, the range being $23000-35300$ FIM/ ha. The lowest price for arable land was paid in the areas of the Agricultural Advisory Centers of Etelä-Karjala, Pirkanmaa, ItäHäme, and Kymenlaakso. The real price of arable land varied from 15700 to 28300 FIM/ha during the years in question.

The increase in the real prices of the purchases of the National Board of Agriculture were very moderate during $1972-1986$. The average value of the annual changes was assessed to be $1.7 \%$. The quantity of subsurface drained and open drained arable land had a strong effect on the price of arable land acquired by the National Board of Agriculture. During the period 1978-1986, subsurface drained arable land cost $37 \%-60 \%$ more than open drained arable land. In the purchases of the National Board of Agriculture, the price level was about $60 \%$ of that recorded by the National Board of Land Surveying.

Because the results of bookkeeping farms are about a fifth higher than for other farms of the region, a corresponding reduction in level was made in the capitalized values of supplementary arable land. When the reduction in level was taken into consideration, the comparison between capitalized value and market prices showed that the capitalized value of supplementary arable land on cattle farms reached the level of prices paid by the National Board of Agriculture during all investigated years when a duration of return of 15 years and a capitalization rate of $3 \%$ (compare figure 15) were employed. The capitalized value assessed on a duration of ten years failed to attain the price level paid by the National Board of Agriculture. In addition, the level of market prices recorded by the National Board of Land Surveying exceeded, by about 
10000 FIM, the highest capitalized value of cattle farms during the period 1982-1986.

For grain farms, the capitalized value of supplementary arable land did not reach the level of market prices paid by the National Board of Agriculture during the investigated period as a whole (compare figure 16). The capitalized value of supplementary arable land on grain farms was clearly at its highest during 1982-1986, when, despite the reduction, it almost reached the level of market prices paid by the National Board of Agriculture with a duration of return of 15 years and a capitalization rate of $3 \%$. The highest capitalized value of supplementary arable land on grain farms was approximately 16000 FIM/ ha and the market prices recorded by the $\mathrm{Na}-$ tional Board of Land Surveying almost 30000
FIM. Market prices were thus almost twice as high. The capitalized value of supplementary arable land on grain farms proved to be more sensitive to variations in yield level than on cattle farms.

In the assessment of the results of this investigation, it should be noted that bookkeeping farms represent farms that are larger than average, in addition to which they are managed in a rational and intensive way. For this reason, caution is required when generalizing the results. The same argument applies to market prices. Consequently, the results of the investigation only indicate the average capitalized value and market prices of supplementary arable land in southern Finland and there nay be considerable deviations at the individual farm level. 


\section{REFERENCES}

Aalstad, S., Bjorá, E., Holm, A., Hustad, T., Kaurin, T., Stokke, K. \& GrønN, A. 1979. Bruksverdi i landbruket. 134 p. Oslo.

Aalto, W. 1951. Tilusten jyvitys maanjakotoimituksissa. Maanmittaus 26: 71-139.

ABEL, W. 1958. Agrarpolitik. 465 p. 2. Aufl. Göttingen. Aereboe, F. 1919. Die Beurteilung von Landgütern und Grundstücken. 532 p. 52 Tafeln. 2. Aufl. Berlin.

- 1923. Allgemeine landwirtschaftliche Betriebslehre. 691 p. Berlin.

Ahonen, L. 1970. Diskonttausarvo metsän hinnoitusinformaationa. Acta Forest. Fenn. 105: 1-81.

AlA-KANTTI, E. 1981. Lisäpellon hinta ja siihen vaikuttavia tekijöită eräissä Varsinais-Suomen kunnissa vuosina 1975-1978. Hels. yliop. maat.ekon. lait. Pro gradu-työ. 83 p. + 11 liit.

Andersson, Y. 1989. Markpriser i jordbruket. En teoretisk studie belyst med svenska data. Inst. för ekon. och stat. Rapport 15: 1-97.

ANON. 1967. Suomen Asetusk. 1967; 543.

- 1972-1986. Maatalouden taloudellisen tutkimuslaitoksen laskemat tuottaja- ja tarvikehintaindeksit. Maat. tilast. kuuk.kats. Maatilahall. julk. vv. 19731987.

- 1974-1989. Maat. tal. tutk.lait. julk. 31, 32, 34, 36, $41,42,44,46$ ja 59. Tilivuodet $1972-1987$.

- 1977. Maatilalaki. Annettu 18.2. 1977/188.

- 1978. Laki oikeudesta hankkia maa- ja metsătalousmaata 26.5.1978/391.

- 1980 a). Peltojen inventointitutkimus. Maatilahall. julk. 3: 1-26, 2 liit.

- 1980 b). Sara 2000. Salaojitusohjelma 1980-2000. Salaojakeskus 48 p. Helsinki.

- 1980 c). Maatilarekisteri. SVT XLIII:1. Maatilahallitus. Helsinki.

- 1982. Ajankohtaista maatalousekonomiaa. Eri tuotantosuuntaa harjoittavien kirjanpitotilojen tuloksia. Tilivuosi 1980. Maat. tal. tutk.lait. tied.ant. 88: 1-39.

- 1986 a) Kiinteistöarviointisanasto. Suomen kiinteistöarviointiyhdistys r.y. 54 p. Helsinki.

- 1986 b). Tutkimuksia Suomen maatalouden kannattavuudesta. Tilivuodet 1982-1984. Maat. tal. tutk. lait. julk. 51: 1-135.

- 1987. Suomen Tilast. Vuosik. 557 p. Helsinki.

- 1989. Maatilalain lainoitusohje. Maatilahallituksen rahoitustoimiston 1.1.1989 laatima ohje.
Barlowe, R. 1958. Land resource economics. 585 p. New Jersey.

BarNaRd, L. \& Nix, J. 1973. Farm planning and control. 549 p. Cambridge.

BJóR, B-C. 1984. Kansantaloudellinen laskentakorkokannan empiirinen määrittäminen. Liiketal. Aikak. 4: $446-472$.

Вцонм, G. 1966. Die Neuorientierung der Landwirtschaft. 143 p. Stuttgart.

Brandes, W. \& Woermann, E. 1969. Landwirtschaftliche Betriebslehre. Allgemeiner Teil. 234 p. Hamburg und Berlin.

Brown, M. 1968. On the theory and measurement of technological change. $\mathrm{XII}+214$ p. Cambridge.

Busch, N. 1969. Taxationslehre für Landwirtschaft und Gartenbau. 407 p. Hamburg und Berlin.

Carey, H. C. (ref. Abel, W. 1958).

Cassel, G. 1938. Teoretisk sosialekonomi. 692 p. Stockholm.

Castle, E. N. \& Носн, J. 1982. Farm real estate price components 1920-1978. Amer. J. Agr. Econ. 2: $8-18$.

CLARK, C. 1973. The value of agricultural land. $117 \mathrm{p}$. New York.

Clark, J. B. 1923. The distribution of wealth. A theory of wages, interest and profits. XXVIII +445 p. New York.

Crowley, W. 1974 a. Farmland use value versus market prices in the three Oregon land markets. U.S. Dept. Agric. 550: 1-19.

- 1974 b. Actual versus apparent rates of return on farmland investment. Agric. Finance Rev. 35, 10: 52-57.

Dolı, J. P. 1974. On exact multicollinearity and estimation of the Cobb-Douglas production function. Amer. J. Agr. Econ. 56: 556-563.

Doll, J., Widdows, R. \& Velde, P. 1983. The value of agricultural land in the United States. A report on research. Agr. Econ. Res. 2: 39-44.

Elstrand, E. 1962. Økonomisk klassifisering av jord. Et metodestudie. Norg. Landbr.økon. Inst. Stensilert særmeld. 8: 1-77.

- 1980. Verdsetting av landbrukseiendommer og jordarealer. Norg. Landbr.økon. Inst. 156 p. Oslo.

— \& Sønıu, K. 1978. Bruksverdier og kostnadsverdier for landbrukseiendommer. Prinsipper for verdsetting 
og eksempler på verdier for hele eiendommer. Norg. Landbr.økon. Inst. 129 p. Oslo.

Feuerstein, H. 1970. Bestimmungründe der Preise und des Transfers land-und forstwirtschaftlich genuzten Bodens. Eine ókonometrische Analyse des schleswigholsteinischen Bodenmarktes von 1954 bis 1968. Diss. 184 p. Kiel.

Found, W. 1971. A theoretical approach to rural landuse patterns. 189 p. London.

GABR, M. 1972. Modelle zur Charakterisierung der Grenzertragsböden bei landwirtschaftlicher Nutzung. Diss. 165 p. Giessen.

Goltz, T. von der 1905. Handbuch der landwirtschaftlichen Betriebslehre. 706 p. 3. Aufl. Berlin.

GoNNER, E. C. K. 1891. Kansantalouden ja verotuksen periaatteet. Suom. B. Tuunanen v. 1937. 451 p. Porvoo.

Griesbach, H. 1966. Der Einfluss des technischen Fortschritts auf die Preise landwirtschaftlich genutzten Bodens in Industrieländern. Volksw. Schr. 104: 1126.

Gryst, W. \& Timmons, J. 1961. The economic role of land resource institutions in agricultural adjustment. In Iowa State University of Science and Technology. Center for Agricultural and Economic Adjustment. Dynamics of land use: needed adjustment. p. 252277. Ames, Iowa.

Gulbrandsen, O. \& LindBeck, A. 1969. Jordbruksnäringens ekonomi. 284 p. Stockholm.

Gustafsson, C., Lind. h., lundstróm, S. \& Persson, E. 1978. Vărdering av landbruksfastigheter. Metoder och principiella frågor. Tekn. högsk. Medd. 5: 6. 221 p. Stockholm.

HanNILA, P. 1980. Lisămaaksi ostetun pellon hinta Seinăjoen maatalouspiirin alueella. Hels. yliop. maat. ekon. lait. Pro gradu-työ. 74 p. +12 liit.

Hayami, Y. \& Ruttan, V. W. 1971. Agricultural development. An international perspective. XIv +367 p. Baltimore and London.

Heady, E. O. 1949. Basic economic and welfare aspects of farm technological advance. J. Farm Econ. 31: 296-297.

Heady, E. O. \& Dillon, J. L. 1972. Agricultural production functions. 667 p. Ames, Iowa.

Heertje, A. 1977. Economics \& technical change. VII + 334 p. London.

HeıKKILĀ, A-M. 1987. Lypsykarjayritysten optimaalinen koko. Maat. tal. tutk.lait. tied.ant. 132: 1-70+ liitt.

HeıkKınen, J. 1978. Lisämaan hinta eräissä Kainuun kunnissa vuosina 1973-75. Hels. yliop. maat.ekon. lait. Pro gradu-työ. 82 p. +2 liit.

Heinonen, S. 1980. Peltoalan kasvun vaikutuksista maatilan talouteen. Maatilahall. julk. 1: $1-138+25$ liit.

Heiskanen, O. 1977. Maa- ja metsätalousmaan hinnanmuodostuksesta Mikkelin läänissä 1.4.1975-31.8. 1976 tehdyissä kaupoissa. Maanmitt.hall. moniste. $67 \mathrm{p}$.
- 1983. Maa- ja metsătalousmaan jyvitysperusteisen arvon määrittäminen. Maanmitt. hall. julk. 50: 1-153.

- 1987. Maa- ja metsătalousmaan jyvitysperusteisen arvon mäărittămisestä (jatkotutkimus). Maanmitt.hall. 116 p. Helsinki.

HemilÃ, K. 1983. Measuring technological change in agriculture. An application based on the ces production function. Maatal.tiet. Aikak. 54: 165-223.

Herdt, R. W. \& Cochrane, W. W. 1966. Farm land prices and farm technological advance. J. Farm. Econ. 48: $243-263$.

HJELM, L. 1952. Jordbruksfastigheternas prisutveckling. Medd. från Jordbr. Utredningsinst. 7: 1-32.

- 1963. Det svenska lantbrukets efektiviseringsvägar. Undersökning utförd på uppdrag av 1960 års jordbruksutredning av professor Lennart Hjelm i samråd med en expertgrupp inom utredningen. Stat. off. utredningar 66: 1-241.

Holmsten, M. \& Myrrberg, O. 1986. Pellon hinta Suomessa vv. 1981-85. Maanmitt.hall.julk. $55.43 \mathrm{p}+13$ liit.

Hovı, L. \& Jokinen, O. 1974. Peltoalueen ja talouskeskuksen vălisten kulku- ja kuljetuskustannusten määrittelemisestä. Valt.tekn.tutk.kesk.Maank.labor. 9: $1-35$.

Нинтамӓкı, A. 1985. Sukupolvenvaihdos maatilalla. Maatal.yritt. elăkelait. julk. 4: $1-93+$ liitteet.

HYvönEn, V. 1982. Kiinteistőjärjestelmä ja kiinteistönmuodostamisoikeus. 767 p. Espoo.

IHAMUOTILA, R. 1968. Viljelijöiden työtulojen taso kirjanpitotiloilla 1956-1965. Maat. tal. tutk.lait. julk. 10: $1-172$.

- 1971. Păăoman merkityksestä tuotannontekijănä Suomen maataloudessa vuosina 1948-1970. Osuuspankkijärjestön taloudellinen katsaus 2: 1-8.

- 1983. Suomen maatalouselinkeinon paaamakanta ja velkaisuusaste vuosina 1961-1980. Hels. yliop. maat.ekon.lait.julk. 10: 1-138.

- \& Stanton, B. F. 1970. A balance sheet of agriculture for Finland 1948-1967. Maat. tal. tutk.lait. julk. 20: $1-122$

IкÄнеІмо, Е. 1979. Taаjamien lievealueiden maatalous. Maatal.hall. Aikak. 9, 1: 27-32.

JAGGI, E. 1945. Methodik und Technik der Ertragswertschătzung landwirtschaftlicher Betriebe und Grundstücke. 138 p. Brugg.

Johsson, R. W. M. 1971. Trends in rural land prices in New Zealand 19541969. Agric. econ. res. unit techn. pap. 4: 1-44.

Johnston, W. E. \& Bischoff, T. 1971. Zur Betriebsgrösse auf Ackerbaustandorten unter Berücksichtigung neuer technischer Fortschritte. Agrarwirtschaft 20: $117-125$.

Jergensen, A. \& Jørgensen, N. 1971. Nogle faktorers indvirkning pá ejendomspriserne $\mathrm{i}$ landbruget. Det landøkon. Driftsbur. 70 p. København.

JUVONEN, E. 1983. Työn ja pääoman vaikutus maatalous- 
tuloon. Maat. tal. tutk.lait. tied.ant. 101: 1-61.

KAARLEhto, P. 1954. Maatalousmaan arvioimisesta Yhdysvalloissa. Maatal.tiet. Aikak. 2: 61-78.

Kanerva, V. 1974. Asunto- ja liiketonttien hintojen ja niihin vaikuttavien tekijöiden määrittäminen monimuuttujamenetelmän avulla. VTT:n rak.tal. lab. tied.ant. 35: 1-109.

- 1978. Tontin hinta ja rakennuskustannukset. Valt. tekn. tutk.kesk. Rakennus- ja yhdyskuntatekniikka. Julk. 21: $1-84+11$ liites.

- 1980. Kiinteistön arviointi. 144 p. Helsinki.

Kantola, J. 1967. Tutkimus asunto- ja liiketonttien hinnanmuodostuksesta eräissä Uudenmaan läänin asutuskeskuksissa. Tekn. korkeak. maanmitt.os. Lis.työ. $185 \mathrm{p}$.

- 1977. Rakennusarvioinnin käsikirja. Maanmitt.hall. julk. 43: 1-105.

- 1978. Ekonometrinen tutkimus käytännön arvioinnissa. Insinöörijärj. koulutuskesk. julk. 87-78, II: $1-15$.

- 1979. Tutkimus maan hinnasta sekä rakennuksen omaisuusosa-arvon ja nykyarvon suhteesta Hämeenlinnan ympäristössä. Maanmitt.hall. julk. 46: 1-172.

Kehrberg, E. \& Reisch, E. 1969. Wirtschaftslehre der landwirtschaftlichen Produktion. 263 p. München.

Kettunen, L. 1966. Om produktionfunktionens form. NJF:s sært. 48,1: 1-19.

— \& Rouniainen, J. 1972. Aggregate livestock and total production functions in Finnnish agriculture in 1956/ 57-1969/70. Maat. tal. tutk.lait. julk. 28, 2: 1-54.

- \& Torvela, M. 1969. Tuoton ja tuotantopanosten intensiteettitaso ja keskimäăräinen riippuvuus maataloudessa. Hels. yliop. kansantal.tiet. lait. tutk. 7: $1-80$.

Korpela, A. 1978. Taloutemme rakenne ja toiminta. 210 p. Helsinki.

Koutsoyiannis, A. 1985. Modern microeconomics. 581 p. London.

KuKKonen, P. 1990. Suullinen tiedonanto.

KulhiA, H. P. 1943. Mallitilusten jyvitys. Suom. maanmitt.yhd. Aikak. 6-8: 160193.

KURKı, M. 1982. Suomen peltojen viljavuudesta 3. 181 p. Helsinki.

LARSSON, G. 1954. Värdering av fastighetens jordbruksdel. Svensk lantmäteritidskr. 1: 56-76.

LAtukKa, A. 1989. Poistonalaisten omaisuusosien arvostaminen ja sen vaikutus maatalouden liiketuloksiin vuosina 1968-1986. Hels. yliop. maatal.ekon. lait. Pro-gradu-tyő. 120 p.

LAUR, E. 1928. Grundlagen und Methoden der Bevertung, Buchhaltung und Kalkulation in der Landwirtschaft. 857 p. 3. Aufl. Berlin.

- 1930. Einführung in die Wirtschaftslehre des Landbaues. 346 p. 2. Aufl. Berlin.

- \& Howald, O. 1957. Bewertung, Buchhaltung und Kalkulation in der Landwirtschaft. 243 p. 4. Aufl. Hamburg und Berlin.
Laurila, I. 1986. Pellolla on monta hintatasoa. Maatal.hall. Aikak. 3: 15-23.

- 1988. Pellon markkinahinta. Johdatus teoreettiseen keskusteluun ja empiiriseen analyysiin. Maatilahall. julk. 15: 1-134.

Leponiemi, A. \& LAmmi, K. 1968. Maatalouskiinteistöjen kauppahinnat Suomessa 1961, 1962 ja 1966. Kyösti Haatajan rah. tutk.tston julk. D. 1968: 1: 1-44. Mimeogr.

— \& LindBERG, J. 1966. Tilastollinen selvitys maatalouskiinteistőjen hinnoista v. 1961. Osuuskassajärjestön tal. kats. 1966, 4: 141-145.

Locken, G., Bills, N. \& Boiswert, N. 1978. Estimating agricultural use values in New York state. Land Economics 54, 1: 50-63.

- 1979. Estimating agricultural use values in New York state: Reply. Land Economics 55, 3: 408-410.

Marshall, A. 1920. Principles of economics. An introductory volume. 871 p. 8 th Ed. London.

Matikainen, K. 1980. Maa- ja metsătalousmaa-alueiden arvioiminen. Ohje. Valt. tekn. tutk.kesk. Rakennustal. laborat. Moniste. 8 p. +3 liit.

Meimberg, P. 1956. Landwirtschaftliches Rechnungswesen. 540 p. Stuttgart.

Murray, W. G. 1969. Farm appraisal and valuation. 534 p. Ames, Iowa.

Myrrberg, O. 1969. Tutkimus omakoti- ja ranta-asutuksen kehityksestä sekä kieltojen ja rajoitusten vaikutuksesta siihen eräissä Uudenmaan läänin kunnissa. Tekn. korkeak. maanmitt. os. Lis.tyő. 160 p.

- 1981. Raakamaan arvioinnin perusteet. Valt. tekn. tutk.kesk. tied. 31: $1-62$.

Myhrberg, O. \& VăAñănen, J. 1988. Pellon ja hajaasutusrakennuspaikkojen hintaindeksit. Maan.mitt. hall. julk. 63:1-51 p. + liitt.

MĀKELĀ, E. 1977. Lisämaaksi ostetun pellon hinta eräissä Kymenlaakson kunnissa vuosina 1973-1975. Hels. yliop. maanvilj.tal. lait. Laudaturtyö. 75 p.

MĀKı, A. 1945. Viljelysmaan pakkolunastuksen vaikutuksesta luovuttavan viljelmăn maatalouteen ja sen kannattavaisuuteen. Suom. Maatal.tiet. Seur. julk. 58: $1-59$.

- 1963. Maatalouden korvauskysymykset tietoimituksissa. Maanmittausinsinööri 4. Erip. 12 p. Turku.

- 1964. Maatalouden tuotantovälineet. Maanvilj. tietok. 3: 89-159. Porvoo.

MÄKINEN, P. 1988. Suomen maatalouden rakennemuutos. Tutkimus rakennemuutokseen vaikuttaneista tekijöistä ja Markovin ketjujen käyttömahdollisuuksista rakennekehityksen ennustamisessa. Hels. yliop. maat. ekon. lait. Lis. tyő. 178 p.

Neuкомм, W. 1947. Untersuchung über die Anwendbarkeit der Rohertragsmethode. 87 p. Bern.

NiEHANS, J. 1966. Eine vernachlässigste Beziehung zwischen Bodenpreis, Wirtschaftswachstum und Kapitalzins. Schw. Z. für Volkw. und Statistik. 102: 195200. 
Nıтамо, O. 1969. Tuotantofunktio, sen jäännöstermi ja teknillinen kehitys. Tilast. päătoim. monist. tutk. 9: $1-49$.

NosıtschKa, H. 1973. Ein Beitrag zur Erklărung der Preisbildung landwirtschaftlich genuzten Bodens. Diss. 211 p. Frankfurt.

OTt, A. E. 1959. Technischer Fortschritt. Handwörterbuch der Sozialwissenschaften. p. 302-316. Stuttgart.

Pekkarinen, J. \& Sutela, P. 1981. Kansantaloustiede. Johdatus perusteisiin. 261 p. Porvoo.

Penrose, E. 1959. The theory of the growth of the firm. 272 p. Oxford.

Pessı, Y. 1964. Suomen ilmasto ja saăolot. Maanvilj. tietok. 1: 19-34. Porvoo.

Petrini, F. 1964. Competition between agriculture and forestry under Swedish conditions. Lantbr.högsk. Ann. 30: 1-333.

PihKala, K. U. 1965. Possibilities of comparing land use for farming and forestry. Acta Agric. Scand., Suppl. 14: $1-56$.

- 1975. Economics of forest land clearing for agriculture. J. Sci. Agric. Soc. Finland. 47, 4: 283-368.

- \& Lasola, T. 1973. Kainuulaisen uudistilan edullisin suuruus ja tuotantosuunta. Maatal.tiet. Aikak. 45, 4: $325-460$.

Plaxico, J. S. \& Kletke, D. D. 1979. The value of unrealized farm land capital gains. Amer. J. Agr. Econ. 5: $327-330$.

Preuschen, G. 1968. Zweckmässig rationalisieren. 131 p. Hamburg.

RASMUSSEN, S. 1981. Beregning af en landbrugsejendoms brugsværdi. Jordbr.økon. Inst. Rapp. 1: 1-34.

Reichel, H. 1973. Überprüfung der Ergebnisse der Reichsbodenschătzung auf ihren ökonomischen Aussagewert unter heutigen Produktionsbedingungen. Diss. 101 p. Hohenheim.

RenBorg, U. \& Karlsson, H. 1969. Företagets tillvăxt. Akt. från lantbr.högsk. 142: 1-43.

RenNe, R. 1947. Land economics. Principles, problems and policies in utilizing land resources. $736 \mathrm{p}$. New York.

Reynolds, J. E. 1966. An econometric investigation of farmland values in the United States. Diss. 185 p. Iowa.

— \& Timmons, F. 1969. Factors affecting farmland values in the United States. Agr. and home econ. exp. stat., Iowa State Univ. Sci and Techn., Res. Bull. 566: 324-351.

Ricardo, D. (ref. Gonner, E.C.K. 1891).

RothKegel, W. 1950. Geschichtliche Entwicklung der Bodenbonitiering und Wesen und Bedeutung der deutschen Bodenschätzung. $147 \mathrm{p}$. Stuttgart.

- 1952. Landwirtschaftliche Schătzungslehre. 188 p. 2. Aufl. Stuttgart.

Roumiainen, J. 1972. Aggregate crop production functions in Finnish agriculture in 1956/57-1968/69. Maat. tal. tutk.lait. julk. 28:1-71.
RYYNĀNEN, V. 1962. Maatalousmaan luovutus yleisiin tarpeisiin ja sen vaikutus viljelmän omaisuuden arvoon sekă viljelmältă saatavaan tuloon eräissă Pohjois-Karjalan kunnissa. Hels. yliop. maan.vilj.tal. lait. Lis.työ. 188 p.

- 1967. Viljelmäăn kuuluvan maatalousmaan osittaisen pakkolunastuksen aiheuttamien menetysten arvioiminen. Suom. Maatal.tiet. Seur. Julk. 110: 1-165.

- 1970. Tutkimuksia maatalouden tuotantofunktioista Sisă-Suomen kirjanpitoviljelmillă vuosina 19601966. Acta Agr. Fenn. 120: 1-65.

- 1972. Teknisen kehityksen edellyttămän tilakoon ja vallitsevan tilakoon vălinen kuilu. Virkaanastujaisesitelmä. Hels. yliop. maatal.ekon. lait. julk. 9: 1-11.

- 1978 a. Maatalouskiinteistőjen arvo ja arvioimisongelmat. Maatalouspolitiikan saroilta. Samuli Suomelan 60-vuotisjuhlajulk. p. 77-85.

- 1978 b. Arvioimistieteen perusteita ja menetelmiă. Hels. yliop. maatal.ekon. lait. julk. 1: 1-58, 11 liit.

- 1981. Tavoitteena yritystoiminta ja elämänmuoto. Maatalouden kaksi roolia tekevăt elinkeinosta vakaan. Lyh. Studia Agraria-sarjan luennosta. Erip. Maaseudun Tulevaisuus n:o 123.

- 1989. Laskentakorkokanta kiinteistöarvioinnin sovellutuksissa. Suom. kiint.arv.yhd. juhlajulk. 10 vuotta. p. $40-47$.

— \& POL.KKı, L. 1982. Maanviljelystalous. 265 p. Helsinki.

Schun, G. E. \& Scharlach, W. C. 1966. Quantitative analysis of some farm and non-farm determinants of agricultural land values - impact of economic development. Res. bull. 821: 1-24.

SCOFIELD, W. 1957. Prevailing land market forces. J. Farm Econ. Vol. 39, 5: 1500-1523.

- 1964. Land prices and farm earnings. Farm real estate market developments. U.S.D.A. Econ. Res. Serv. 66: 39-45.

- 1965 a. Land prices and farm earnings. Appraisal J. 33: $100-113$.

- 1965 b. Land return and farm income. Farm real estate market developments. U.S.D.A. Econ. Res. Serv. 67: 44-52.

Siebert, H. 1969. Einführung in die Volkswirtschaftslehre. Teil I: Preistheorie. 180 p. Stuttgart-BerlinKöln-Mainz.

Sırrola, J. 1988. Ansiotulojen verotus maatalousverotuksessa. Hels.yliop.maatal.ekon. lait. Pro-gradu-tyō. $68 \mathrm{p}$.

Siltanen, L. \& Ala-Mantila, O. 1989. Maatalouden kokonaislaskelmat 1980-1988. Maat. tal. tutk.lait. tied.ant. 151: 1-56.

Sкомrосн, W. 1962. Bestimmungsgründe und Berechnung des Zinsanspruchs. Ber. über Landw. 40, 4: 813-844.

Strobehn, R. 1966. Resource productivity and income distribution with implications for farm tenure adjustment. III. Agr. Exp. Sta. Bull. 720: 1-35. 
Suomela, S. 1958. Tuottavuuden kehityksestä Suomen maataloudessa. Maat. tal.tutk.lait. julk. 1: 1-128

Suter, R. 1976. The appraisal of farm real estate. 613 p. Illinois.

ThaER, A. 1880. Grundsätze der rationellen Landwirtschaft. 1100 p. Berlin.

Thúnen, G. H. von 1875. Isolierte Staat in Beziehung auf Landwirtschaft und Nationalekonomie. 876 p. 3. Aufl. Berlin.

Tolonen, S. 1985. Lisămaiksi siirtyneiden peltojen käyttö. Maatal.yritt.eläkelait. julk. 5a: 1-43.

TORVELA, M. 1966. Tuotantopanosten käytöstä ja käytön edullisuudesta maataloudessa Etelă-Suomen kirjanpitoviljelmillä. Maat. tal. tutk.lait. julk. 8: 1-141.

- 1980. Yrityskoko kotieläintaloudessa. Maatalous 73: 104-106.

— \& MĂKı, S. 1974. Perheviljelmăn koko rationaalisessa maataloustuotannossa Maat. tal. tutk.lait. julk. 30: $1-79$.

TURKKı, A. 1982. Tuotantopanosten käytön vaikutus maidontuotannon kannattavuuteen. Hels. yliop. maat.ekon. lait. julk. 8: 1-68.

Tweeten, L. 1969. Theories explaining the persistance of low resource returns in a growing farm economy. Amer. J. Agr. Econ. 51: 798-81.

Ulvinen, O. 1980. Siemenviljan ja öljykasvien siementavaran tuotannon alueellinen jakauma vuoden 1979 viljelystarkastuksissa. Kylvősiemen 2: 27-29.

Upton, M. 1976. Agricultural production economics and resource use. 357 p. Oxford University Press.

VALKAMA, H. 1979. Pellon hinnan kehityksestă maamme eri alueilla 1960-1977 sekä lisämaan käyvästä hintatasosta v. 1978. Pellervon tal. tutk.lait. raportteja ja artikkeleita 1: 1-38, 6 liit.

VARTIAINEN, H. 1963. Hinnanmuodostus. Yhteiskuntatieteiden käsikirja I:135-151. Helsinki.

Virolainen, J. 1950. Maatalousmaan arvioimisesta ja arvosta Suomessa vuosina 1934-1938. Suom. Maatal. tiet. Seur. Julk. 72: 1-283.

VIRTANEN, P. V. 1966. Maan arvoon vaikuttavat seikat kaupungissa. Suomen kaupunkiliitto. 98 p. Karhula.

- 1978. Kaupunkimaan arvonmuodostuksen teoriaa. Maanmittaus 3-4:14-48.

- 1979. Kaupunkimaan arvioinnin perusteet. 189 p. Espoo.

VUORINEn, J. 1952. Peltojen luokitus ja arvosuhteet viljavuustutkimuksen valossa. Maanmitt.ins. Liiton Aikak. 10-11:419-427.

Weber, A. 1973. Arbeit- und Bodensparende Technologien. Agrarwirtschaft 2:57-68.

Weckman, K. J. 1970. Production allocation in Finnish agriculture. Suom. Maatal.tiet. Seur. Julk. 117: 1116

WentruP, C. 1978. Bestimmungsgründe für Bodenpreise. Bonner Hefte für Agrarpolitik und Agrarsoziologie. Heft 5. 101 p. Stuttgart.

Westermarck, N. 1967. Ohjeita katetuotto-menetelmän mukaisen taloussuunnitelman laatimiseksi. Maatal. seur. Keskusl. Julk. 534: 1-55.

WiralA, A. 1958. Tiluslaji- ja jyvitysoppi. Maanjaon arvioimisoppi I: 1-108.

- 1960. Tiekorvaukset. Maanjaon arvioimisoppi III. 202 p. Vammala.

- 1966. Pakkolunastus- ja tilikorvaukset. Maanjaon arvioimisoppi II. 249 p. Vammala.

- 1976. Kiinteistöarvioinnin käsikirja. 275 p. Otaniemi.

WILleR, H. 1967. Technischer Fortschritt und Landwirtschaft. 218 p. Hamburg und Berlin.

YLĀTALO, M. 1978. Maan tuottoarvo ja siihen vaikuttavat tekijăt eräillă Etelä-Suomen kirjanpitotiloilla vuosina 1968-1972. Hels. yliop. maanvilj.tal. lait. julk. 5: $1-107$.

- 1987. Maatalouden investoinnit ja tuottavuus. Pellervon tal. tutk.lait. julk. 8:1-94.

ÄNKo, O. 1968. Maan hintataso Helsingin seudulla v. 1967. Valt. tekn. tutk. lait. julk. 143: 1-75. 


\section{Basis for the assessment of capital values}

The estimation of production functions on the basis of farm data is made particularly problematic by the revaluation of agricultural property values. Following the fiscal reform of 1968, agricultural accounting adopted the same property values as used in taxing the values of farm buildings, equipment, and land improvements. Accordingly, depreciations in accordance with the taxation of the property parts concerned were implemented in bookkeeping activities.

Because the profitability survey, as well as other bookkeeping activities, does not take into consideration the effect of inflation, agricultural property values have, little by little, fallen behind their real market value. This is particularly the case regarding the values of machines, equipment, farm buildings, and subsurface drainage, on which the estimations of production function are based. It was therefore, considered important in this study to adjust the tax depreciable property values in order to prevent the decrease in real value of properties caused by inflation.

In this case, the adjustment of property items, in accordance with bookkeeping practice, is made separately for farm buildings, machines, and land improvements ${ }^{1}$. The value determined for the depreciable property items in agriculture, in connection with the fiscal reform of 1968 , is used as a starting point. The adjustment is made by multiplying the non-depreciated investment of each farm and property item at the beginning of 1968 , by a coefficient of correction that corresponds to the percentile rise of the cost-of-living index or inflation in 1968. After that, the revised depreciation is subtracted from the revaluated assets, and, thus, the non-depreciated investment at the end of the year is obtained.

Investments and sales (mainly machines) are adjusted in the following way: investments and sales in accordance with agriculture taxation are assumed to have occurred in the middle of the fiscal year and, thus, their difference is multiplied by a coefficient of correction that corresponds to six month's inflation. After this, the depreciation on six months is subtracted from the revaluated

I In this respect, the possibility to use the investment accumulation approach, in accordance with national accounting, was examined. It required gross investment accumulation series for the properties in question corresponding to their duration. The bookkeeping data used in this study does not contain information on investment accumulation for far enough back in time, especially concerning buildings and subsurface drainage. investments, giving the value of investments at the end of the year. The sum of depreciations on investments and depreciations on non-depreciated investment are the revaluated real depreciations of 1968. Correspondingly, the sum of investments at the end of the year and nondepreciated investments are non-depreciated investments in the beginning of 1969 that are to be adjusted. In this way, adjustment is continued until 1986 .

Agricultural investments are considered in accordance with taxation practices, i.e. they include costs of investments, the value of own timber, and the value of external labour used for investments. Sales consist of sales income, compensation for damage, insurance and others, as well as grants. The revaluated procedure is shown as follows:

$\begin{aligned} A_{1+1}= & {\left[A_{t}\left(1+p_{1}\right)-A_{t}\left(1+p_{1}\right) p_{0}\right]+\left[I_{t}\left(1+p_{1} / 2\right)-\right.} \\ & \left.I_{t}\left(1+p_{1} / 2\right)\left(p_{0} / 2\right)\right]- \\ A_{1+1}= & A_{t}\left(1+p_{1}\right)\left(1-p_{0}\right)+I_{t}\left(1+p_{1} / 2\right)\left(1-p_{0} / 2\right), \text { in which }\end{aligned}$

$A_{1}=$ value at the beginning of the year

$A_{t+1}=$ value at the beginning of the following year

$I_{t} \quad=$ net investment (total investment-sales)

$\mathrm{p}_{1} \quad=$ percentage signifying increase in cost level each year

$\mathrm{p}_{0} \quad=$ percentage of depreciations.

For the determination of costs due to equipment, farm buildings and, land improvements, depreciations are assessed from the revaluated capital values as equal percentages $^{2}$.

The depreciation applied was $19 \%$ for machines, $8 \%$ for buildings, and $6 \%$ for land improvements. It is to be noted that the size of the adjusted depreciations depends on the rate of increase of the index used for adjusting the capital values for inflation, as well as on the percentage of depreciation. The cost-of-living index was chosen for the adjustment because the special indexes (the index of equipment costs and the index of building costs) describe the price development of new property items and therefore include a certain price rise due to technological development, independent of inflation.

The adjusted capital values and the depreciations estimated from them are used in this investigation for the assessment of costs derived from the cost of equipment, farm buildings, and land improvements.

2 The problems of capital value adjustment and depreciation have been discussed in more detail by YLÁTALO (1987) and LATUKKA (1989); papers which form the basis of the method applied in the present investigation. 


\section{APPENDIX 2}

Estimates of parameters of the Cobb-Douglas function on cattle farms for different years, at 1986 prices.

Table 2.1. Estimates of parameters in 1972.

\begin{tabular}{lccc}
\hline Production input & Parameter & Estimate & t-value \\
\hline Constant & $\log \mathrm{A}$ & 5.18966 & $6.98^{* * *}$ \\
Arable land area & $\mathrm{B}_{1}$, & 0.249253 & $3.36^{* *}$ \\
& $\mathrm{~B}_{1}$, & 0.066866 & $3.37^{* *}$ \\
& $\mathrm{~B}_{1}$, & 0.080809 & $3.74^{* * *}$ \\
Cost of purchased feed & $\mathrm{B}_{2}$ & 0.098730 & $3.03^{* *}$ \\
Cost of purchased fertilizers & $\mathrm{B}_{3}$ & 0.055866 & 1.23 \\
Livestock cost & $\mathrm{B}_{4}$ & 0.198038 & $3.73^{* * *}$ \\
Cost of equipment & $\mathrm{B}_{5}$ & 0.110874 & $2.25^{*}$ \\
Agricultural works & $\mathrm{B}_{6}$ & 0.187752 & $2.50^{* * *}$ \\
Number of farms $=39$ & & & \\
$\mathrm{R}^{2}=0.927$ & & & \\
\hline
\end{tabular}

Table 2.2. Estimates of parameters in 1976.

\begin{tabular}{lccc}
\hline Production input & Parameter & Estimate & t-value \\
\hline Constant & $\log \mathrm{A}$ & 5.093482 & $4.89^{* * *}$ \\
Arable land area & $\mathrm{B}_{1}$, & 0.240730 & $3.07^{* *}$ \\
& $\mathrm{~B}_{1}{ }^{\prime}$, & -0.013142 & -0.78 \\
& $\mathrm{~B}_{1}{ }^{\prime}$ & 0.040965 & $2.12^{*}$ \\
Cost of purchased feed & $\mathrm{B}_{2}$ & 0.175740 & $6.03^{* * *}$ \\
Cost of purchased fertilizer & $\mathrm{B}_{3}$ & 0.157887 & $2.91^{* *}$ \\
Livestock cost & $\mathrm{B}_{4}$ & 0.161474 & $3.33^{* *}$ \\
Cost of equipment & $\mathrm{B}_{5}$ & 0.047505 & 0.84 \\
Agricultural works & $\mathrm{B}_{6}$ & 0.157545 & 1.31 \\
Number of farms $=44$ & & & \\
$\mathrm{R}^{2}=0.938$ & & & \\
\hline
\end{tabular}

Table 2.3. Estimates of parameters in 1980 .

\begin{tabular}{lccc}
\hline Production input & Parameter & Estimate & t-value \\
\hline Constant & $\log \mathrm{A}$ & 4.704700 & $6.87^{* * *}$ \\
Arable land area & $\mathrm{B}_{1}, 1^{* * *}$ \\
& $\mathrm{~B}_{{ }^{\prime}}$, & 0.292734 & 1.43 \\
& $\mathrm{~B}_{1}{ }^{\prime}$ & 0.019995 & $2.61^{* * *}$ \\
Cost of purchased feed & $\mathrm{B}_{2}$ & 0.040190 & $8.29^{* * *}$ \\
Cost of purchased fertilizer & $\mathrm{B}_{3}$ & 0.239892 & $3.15^{* * *}$ \\
Livestock cost & $\mathrm{B}_{4}$ & 0.122267 & $2.43^{* * *}$ \\
Cost of equipment & $\mathrm{B}_{5}$ & 0.084304 & $2.68^{* * *}$ \\
Agricultural works & $\mathrm{B}_{6}$ & 0.153962 & 1.04 \\
Number of farms $=51$ & & 0.078493 & \\
$\mathbf{R}^{2}=0.954$ & & & \\
\hline
\end{tabular}


Table 2.4. Estimates of parameters for the period 1982-1986.

\begin{tabular}{lccc}
\hline Production input & Parameter & Estimate & t-value \\
\hline Constant & $\log \mathrm{A}$ & 5.259936 & $11.66^{* * *}$ \\
Arable land area & $\mathrm{B}_{1}$, & 0.323629 & $6.89^{* * *}$ \\
& $\mathrm{~B}_{1}{ }^{\prime \prime}$ & 0.011470 & 1.25 \\
& $\mathrm{~B}_{1}{ }^{* *}$ & $2.36^{* *}$ \\
Cost of purchased feed & $\mathrm{B}_{2}$ & 0.023014 & $9.27^{* * *}$ \\
Cost of purchased fertilizer & $\mathrm{B}_{3}$ & 0.199133 & $4.32^{* * *}$ \\
Livestock cost & $\mathrm{B}_{4}$ & 0.151382 & $3.11^{* * *}$ \\
Cost of equipment & $\mathrm{B}_{5}$ & 0.102256 & 1.51 \\
Agricultural works & $\mathrm{B}_{6}$ & 0.070035 & $2.01^{* *}$ \\
Number of farms $=155$ & & 0.114403 & \\
$\mathrm{R}^{2}=0.896$ & & & \\
\hline
\end{tabular}




\section{APPENDIX 3}

Estimates of parameters of the Cobb-Douglas production on grain farms for different periods, at 1986 prices.

Table 3.1. Estimates of parameters for the period 1975-1977.

\begin{tabular}{lccc}
\hline Production input & Parameter & Estimate & t-value \\
\hline Constant & $\log \mathrm{A}$ & 5.354686 & $7.79 * * *$ \\
Arable land area & $\mathrm{B}_{1}$ & 0.303332 & $3.28^{* *}$ \\
& $\mathrm{~B}_{1}$, & 0.231422 & $5.80^{* * *}$ \\
& $\mathrm{~B}_{1}{ }^{*}$ & 0.328492 & $7.93^{* * *}$ \\
Cost of purchased seeds & $\mathrm{B}_{2}$ & 0.004665 & 0.87 \\
Cost of equipment & $\mathrm{B}_{3}$ & 0.288103 & $3.41^{* * *}$ \\
Agricultural works & $\mathrm{B}_{4}$ & 0.230291 & $4.92^{* * *}$ \\
Number of farms $=99$ & & & \\
$\mathrm{R}^{2}=0.922$ & & & \\
\hline
\end{tabular}

Table 3.2. Estimates of parameters for the period 1979-1981.

\begin{tabular}{lccc}
\hline Production input & Parameter & Estimate & t-value \\
\hline Constant & $\log \mathrm{A}$ & 6.693207 & $8.79 * * *$ \\
Arable land area & $\mathrm{B}_{1}$ & 0.589511 & $6.52^{* * *}$ \\
& $\mathrm{~B}_{1}$, & 0.115958 & $5.80^{* * *}$ \\
Cost of purchased seeds & $\mathrm{B}_{1}{ }^{*}$ & 0.194612 & $6.68^{* * *}$ \\
Cost of equipment & $\mathrm{B}_{2}$ & 0.010625 & 1.43 \\
Agricultural works & $\mathrm{B}_{3}$ & 0.184585 & $2.01^{* *}$ \\
Number of farms $=102$ & $\mathrm{~B}_{4}$ & 0.113499 & 1.87 \\
$\mathrm{R}^{2}=0.895$ & & & \\
\hline
\end{tabular}

Table 3.3. Estimates of parameters for the period 1982-1986.

\begin{tabular}{lccc}
\hline Production input & Parameter & Estimate & t-value \\
\hline Constant & $\log \mathrm{A}$ & 7.855445 & $24.14^{* * *}$ \\
Arable land area & $\mathrm{B}_{1}$, & 0.585661 & $11.88^{* * *}$ \\
& $\mathrm{~B}_{1}{ }^{*}$, & 0.119776 & $6.11^{* * *}$ \\
& $\mathrm{~B}_{1}{ }^{*}$ & 0.204096 & $10.16^{* * *}$ \\
Cost of purchased seeds & $\mathrm{B}_{2}$ & 0.011301 & $2.52^{*}$ \\
Cost of equipment & $\mathrm{B}_{3}$ & 0.120806 & $3.05^{* *}$ \\
Agricultural works & $\mathrm{B}_{4}$ & 0.073688 & $2.66^{* *}$ \\
Number of farms $=195$ & & & \\
$\mathrm{R}^{2}=0.936$ & & & \\
\hline
\end{tabular}




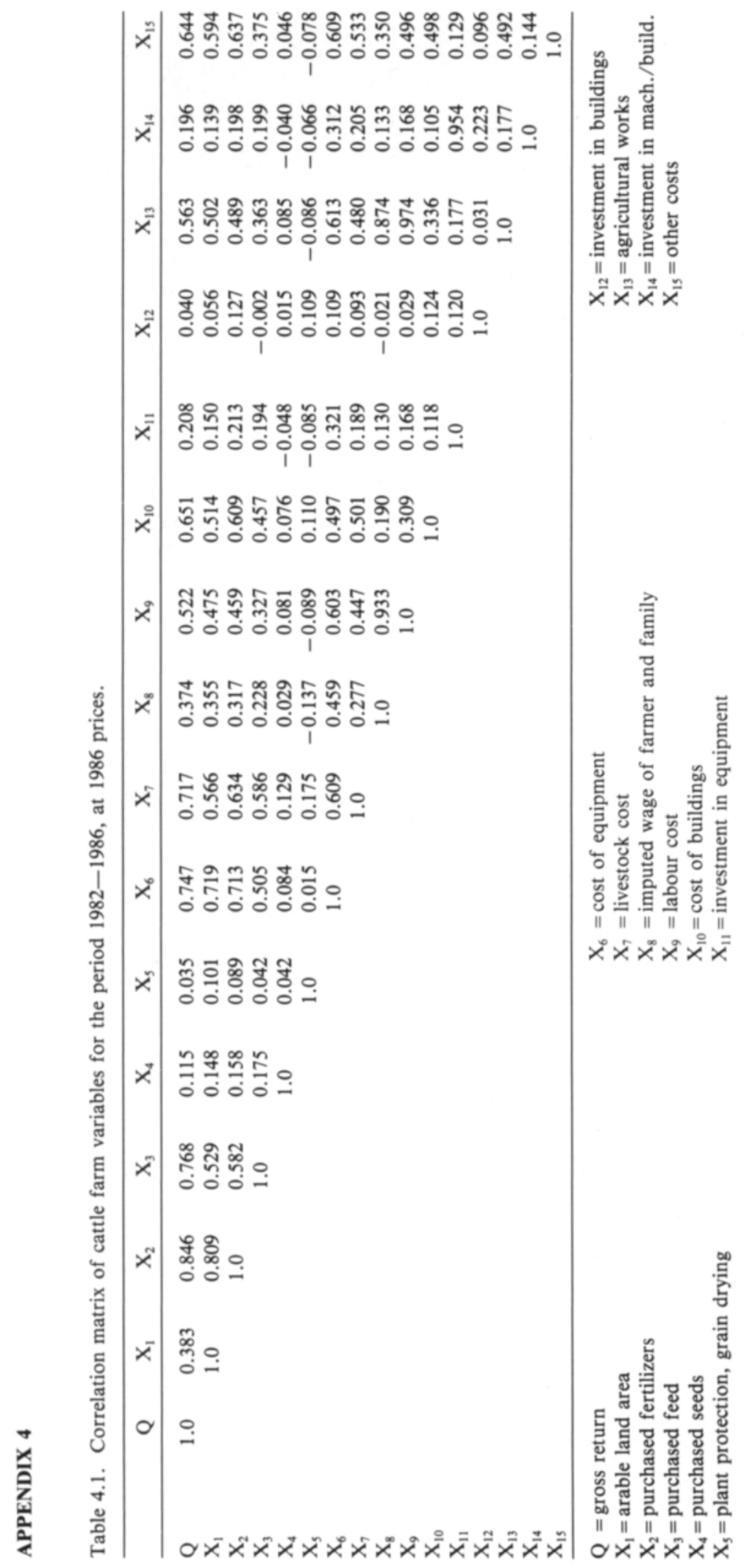




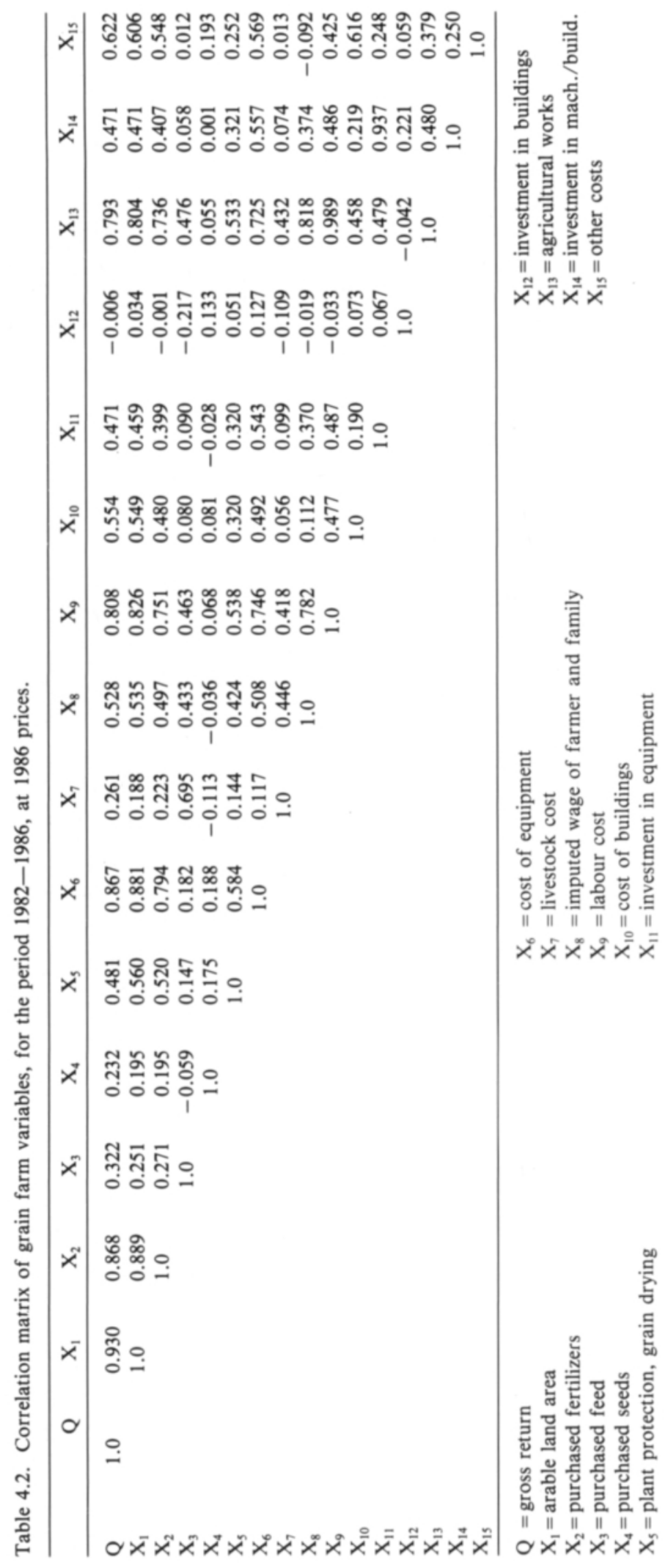


Table 5.1. Average variable costs (FIM/farm) on cattle and grain farms during the period 1982-1986

\begin{tabular}{|c|c|c|c|}
\hline Variable & Cattle farms & Variable & Grain farms \\
\hline $\begin{array}{l}\text { Cost of supplies: } \\
\text { (exl. purchased feed } \\
\text { and fertilizers) }\end{array}$ & 27141.70 & $\begin{array}{l}\text { Cost of supplies: } \\
\text { (exl. purchased } \\
\text { seeds) }\end{array}$ & 67456.71 \\
\hline $\begin{array}{l}\text { Repair and maintenance: } \\
\text { farm buildings } \\
\text { Other costs (exl. } \\
\text { depreciations of } \\
\text { land improvements) }\end{array}$ & 12525.75 & $\begin{array}{l}\text { Repair and maintenance: } \\
\text { farm buildings } \\
\text { Other costs (exl. } \\
\text { depreciation of } \\
\text { land improvements) }\end{array}$ & 14991.87 \\
\hline Total variable costs & 48666.43 & Total variable costs & 91809.05 \\
\hline Gross return & 318958.30 & Gross return & 283905.04 \\
\hline $\begin{array}{l}\text { Variable costs } \% \\
\text { from gross return }\end{array}$ & 15.26 & $\begin{array}{l}\text { Variable costs } \% \\
\text { from gross return }\end{array}$ & 32.33 \\
\hline
\end{tabular}

Notes:

a Assessments are made at 1986 prices. The examination covers only those variable costs that have been excluded from the regression model. Consequently, purchased fertilizers and feed, for example, are not considered as variable costs on cattle farms. 


\section{APPENDIX 6}

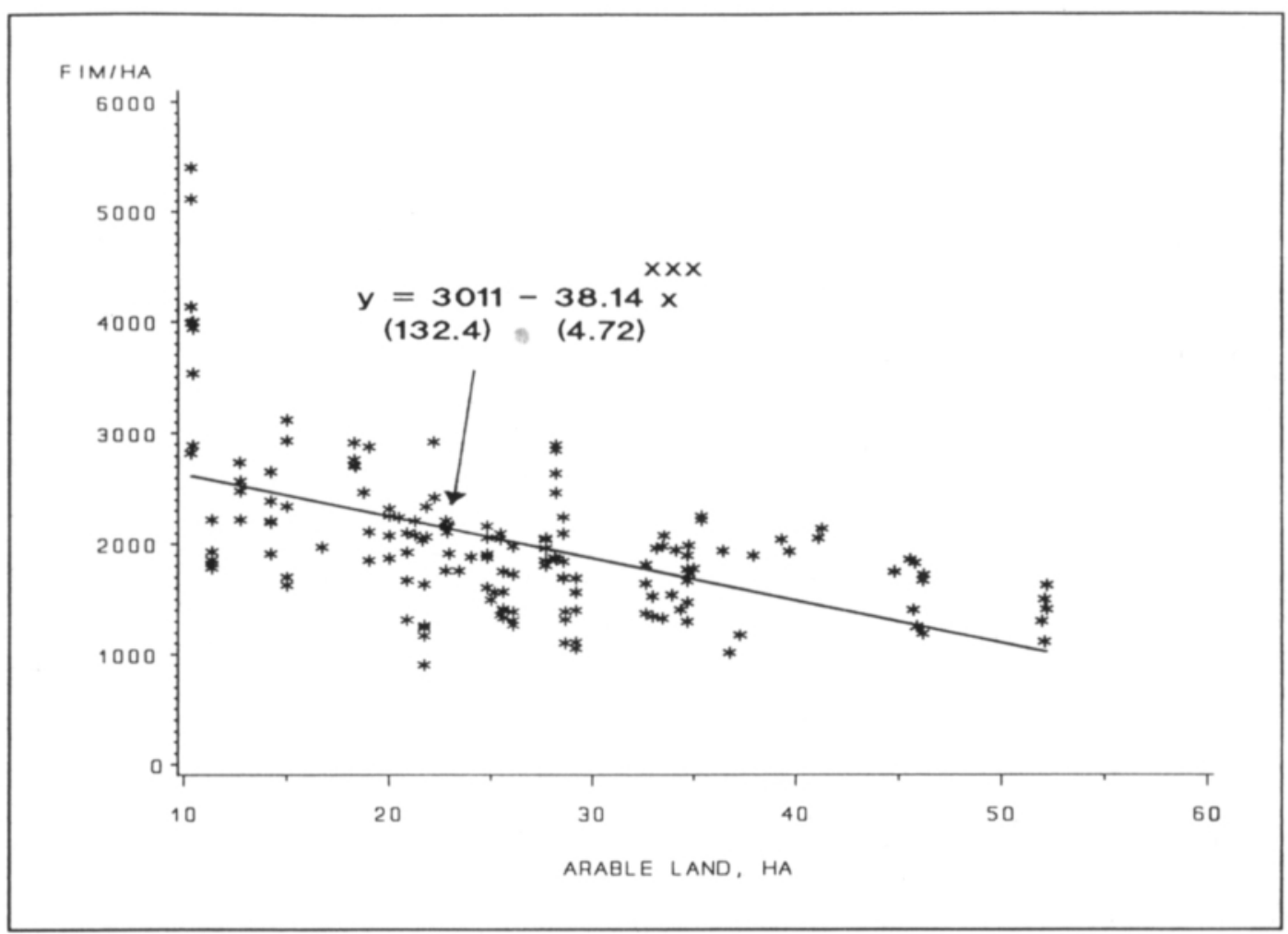

Figure 6.1. Variable costs per farm (FIM/ha) excluded from the models explaining gross return on cattle farms, as a function of farm size during the period $1982-1986$, at 1986 prices. 


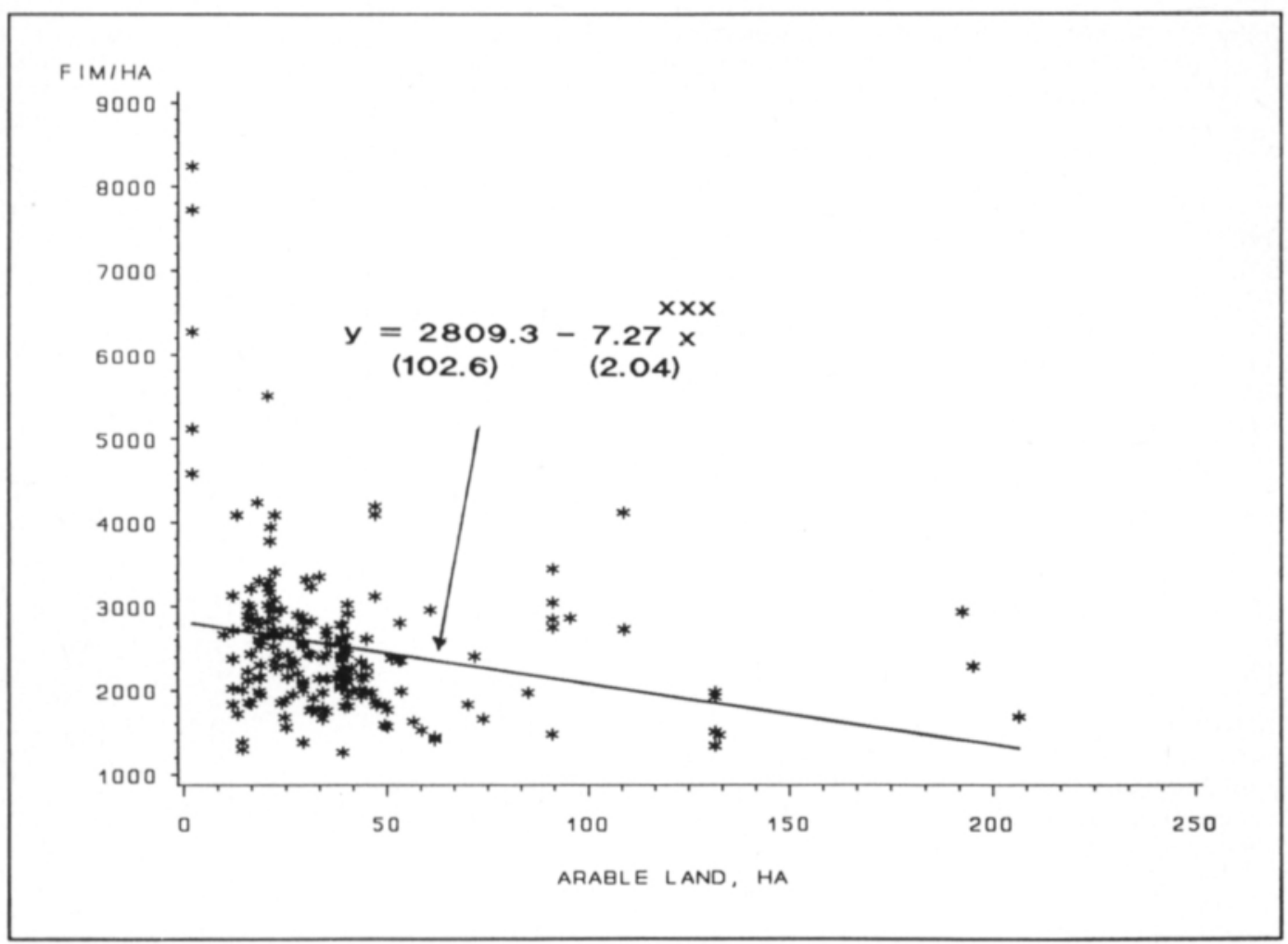

Figure 6.2. Variable costs per farm (FIM/ha) excluded from the models explaining gross return on grain farms, as a function of the farm size during the period 1982-1986, at 1986 prices. 


\section{APPENDIX 7}

Table 7.1. Nominal and real price development of agricultural land (FIM/ha) in land acquisitions by the National Board of Agriculture, 1972-1986.

\begin{tabular}{lcc}
\hline Year & $\begin{array}{c}\text { Nominal moving } \\
\text { 3-year average price }\end{array}$ & $\begin{array}{c}\text { Real price at } \\
1986 \text { prices }^{\mathrm{a}}\end{array}$ \\
\hline 1972 & 3645 & 12495 \\
1973 & 4485 & 17195 \\
1974 & 5340 & 16813 \\
1975 & 5298 & 14743 \\
1976 & 6799 & 14863 \\
1977 & 7892 & 16306 \\
1978 & 9064 & 16741 \\
1979 & 9433 & 17568 \\
1980 & 10413 & 14400 \\
1981 & 11601 & 16585 \\
1982 & 13048 & 17389 \\
1983 & 14393 & 15931 \\
1984 & 14947 & 17521 \\
1985 & 18092 & 15861 \\
1986 & & 22993 \\
\hline
\end{tabular}

Notes:

a The cost-of-living index is used as a deflator. The real price of arable land has been assessed using average prices weighted by the area acquisitions by the National Board of Agriculture, see figure 14. 


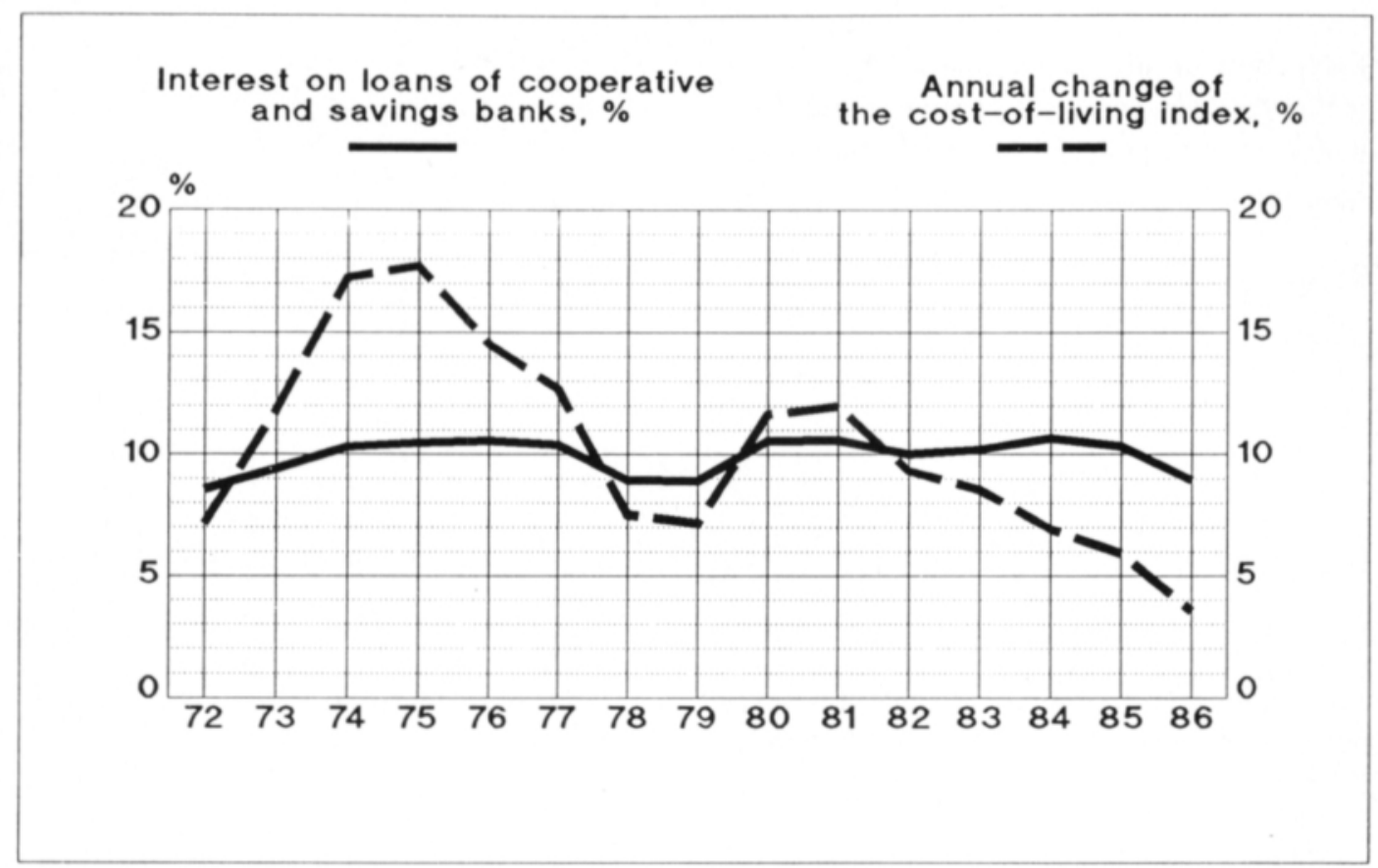

Figure 8.1. Average interest on loans (\%) of cooperative and savings banks and the development of the annual change of the cost-of-living index, 1972-1986. (Assessed using the quarterly lending rates according to the statistics of the Bank of Finland.)

Table 8.1. Price development of plant and livestock products $(1985=100)^{\mathrm{a}}$.

\begin{tabular}{lcc}
\hline Year & Plant products & Livestock products \\
\hline 1972 & 22.9 & 26.2 \\
1973 & 27.6 & 29.2 \\
1974 & 29.5 & 34.4 \\
1975 & 34.9 & 43.5 \\
1976 & 40.6 & 49.1 \\
1977 & 41.3 & 53.2 \\
1978 & 43.5 & 56.3 \\
1979 & 47.5 & 59.5 \\
1980 & 58.0 & 65.6 \\
1981 & 69.0 & 73.0 \\
1982 & 84.1 & 82.3 \\
1983 & 85.9 & 88.5 \\
1984 & 91.4 & 94.0 \\
1985 & 100.0 & 100.0 \\
1986 & 104.7 & 100.9 \\
\hline
\end{tabular}

Source:

a Indexes assessed by the Agricultural Economics Research Institute. 


\section{Lisäpellon tuotto- ja kauppa-arvon määrittämisen perusteet ja soveltuvuus pellon arvon osoittamiseen Etelä-Suomessa vuosina 1972-1986}

\author{
Matti Ylätalo \\ Pellervon taloudellinen tutkimuslaitos, PTT
}

Tutkimuksen tavoitteena oli lisäpellon tuotto- ja kauppa-arvon määrittäminen Etelä-Suomen kirjanpitoalueella vuosina $1972-1986$. Tämă edellytti tarkoitukseen soveltuvien laskentamenetelmien valintaan ja käyttöön liittyvien kysymysten tarkastelua. Tällöin pellon arvon ajateltiin määrăytyvăn pelkästään sen käytöstä viljelytarkoituksiin saatavasta hyödystä. Samoin pellosta maksetut hinnat kuvaisivat pelkästään viljelytarkoitukseen hankitun pellon arvoa ilman ns. odotusarvotekijoitä.

Aluksi tarkasteltiin keskeisiä maatalousmaan arvioinneissa kăytettyjă arvo- ja hintakäsitteită sekä niiden soveltuvuutta eri käyttőtarkoituksiin. Suomen kiinteistöarviointiyhdistyksen hyväksymän terminologian mukaan tuottoarvolla ymmärretään "nykykäytön tai kăyttömahdollisuuksien perusteella arvioidun tuoton pääoma-arvona määritettyă kăypăă arvoa". Vastaavasti kauppa-arvolla tarkoitetaan kauppahintojen perusteella määritettyă käypäă arvoa eli käypäă hintaa. Lisäpellolla tarkoitetaan puolestaan tilan muiden peltojen yhteydessä viljeltaavää jo hankittua tai hankittavaksi aiottua peltoaluetta, jota aiotaan kăyttäă maataloustuotantoon. Näită määritelmiă sovellettiin myős tăssă tutkimuksessa.

Tutkimuksen toisessa luvussa tarkasteltiin lisäpellon arvoon ja hintaan vaikuttavia keskeisiä tekijöitä. Ensiksi tutkittiin pellon laadun sekä kysynnän ja tarjonnan vaikutusta. Tallloin todettiin viljelyteknillisten ja taloudellisten toimenpiteiden vaikutuksen korostuneen maatalouden taloudelliseen tulokseen ja siten myös maan arvoon vaikuttavina tekijöinä, kun taas maan laadun merkitys oli alentunut.

Lisăpellon voimakas kysyntä sen vähäiseen tarjontaan nähden osoittautui pellon hintasoa kohottavaksi tekijäksi, varsinkin kun teknologinen kehitys ja erityisesti koneiden lisääntynyt käyttő olivat tehneet mahdolliseksi hoitaa aikaisempaa suurempaa viljelmäă. Kuilu vallitsevan ja nykyteknologian avulla hoidettavan viljelmäkoon välillă osoittautui suureksi.

Aikaisempien tutkimusten mukaan maataloustuotantoon ja sen kannattavuuteen vaikuttavat tekijăt heijastuvat myös maan arvoon. Siten yksittäisten tekijoiden osuuden erottaminen lisăpellon hintaan vaikuttavista kai- kista tekijöistä osoittautui ongelmalliseksi, vaikka ne kyettäisiinkin ryhmittelemään yleisiin, laadullisiin ja yksilöllisiin tekijöohin.

Luvussa kolme käytiin lävitse aikaisempia tuotto- ja kauppa-arvoperusteisia tutkimuksia sekä niissă sovellettuja menettelytapoja. Aluksi tarkasteltiin tuottoarvon laskennan perusteita ja sen riippuvuutta eri tekijöistä. Sen jălkeen esitettiin kansantaloustieteessă käytetty, maankorkoon pohjautuva lähestymistapa, jota myös on käytetty maatalousekonomisissa tutkimuksissa. Eniten käytetty lisäpellon arvon määrittämismenetelmä maataloudessa on kuitenkin ollut lisäpellon tuoton märittäminen jäănnöksenä, kun muiden tuotantopanosten käytöstä aiheutuvat kustannukset vähennettiin kokonaistuotosta. Keskeiseksi ongelmaksi siină nousi tuotantovälineiden ja panosten käytön erilaisuuden lisäksi niiden hinnoitteluun liittyvăt vaikeudet. Tällă menetelmällă saatiin pinta-alaltaan pienehköillă viljelmillă alhainen tai jopa negatiivinen tuotto pellolle. Kolmantena lisäpellon tuoton laskentamenetelmänă tarkasteltiin rajatuottavuusteoriaan pohjautuvaa lähestymistapaa, jossa tuotantovălineet saavat niiden rajatuottoa vastaavan korvauksen tuotannon tuloksesta. Teorian soveltaminen edellytti tuotantofunktioiden estimointia.

Kolmannen luvun jälkimmăisessă osassa (3.2.) esiteltiin kauppa-arvoperusteisia tutkimuksia sekă todettiin kauppahinta-aineiston saatavuuteen ja edustavuuteen liittyvăt ongelmat. Lisăpellon hintatutkimuksia oli kyllä tehty maassamme useita, mutta pitkän aikavălin hintatilastoja oli saatavissa ainoastaan valtion maanhankintatilastosta ja kaupanvahvistajien hintatilastoista. Siksi Suomessa tehdyt aikaisemmat hintatutkimukset yleensă keskittyivăt yhden suppean alueen tai paikkakunnan kauppahintojen tarkasteluun muutaman vuoden osalta.

Tämän tutkimuksen empiirisessä osassa tutkimusalueeksi valittiin Etelä-Suomi, jolla alueella maatalouden luontaiset edellytykset (maaperă ja ilmasto) ovat parhaat. Lisăpellon tuottoarvon määrittämistă varten tutkimusaineistoksi valittiin kirjanpitoviljelmät, jotka olivat yhtäjaksoisesti olleet mukana maatalouden kannattavuustutkimuksessa vuodesta 1968 lähtien. Lopulliseen tutkimus- 
aineistoon kelpuutettiin kuitenkin vain nautakarja- ja viljatilat, joilla tuotannon katsottiin ensisijaisesti perustuvan viljelysmaan hyvăksikäyttőön.

Ennen tuotantofunktioiden estimointeja kirjanpitoviljelmien poistonalaisten omaisuusosien verotuksenmukaiset arvot muutettiin elinkustannusindeksillă vastaamaan paremmin niiden markkina-arvoja. Muuttujien valinnassa käytettiin hyvăksi korrelaatioanalyysejä ja kokeiluja. Aluksi testattiin eri funktiotyyppejă: lineaarista, CobbDouglas ja erästă transkendentaalifunktiota. Năistă valittiin Cobb-Douglas tuotantofunktio lisăpellon rajatuoton laskentaan. Laskelmat suoritettiin sekä poikkileikkaus- ettă aikasarjatarkastelua kăyttåen vuosilta 197286. Nautakarjatilojen rajatuotot mäăritettiin vuosilta $1972,1976,1980$ ja 1982-86. Viljatilojen vuotuisen satovaihtelun vaikutuksen tasoittamiseksi laskelmat laadittiin kolmen perăttäisen vuoden tietojen pohjalta vuosilta $1975-77,1979-81$ ja ajanjaksolta $1982-86$ koko ajan samassa tuotantosuunnassa pysyneiden viljelmien osalta. Luotettavimmin lisäpellon keskimääräinen rajatuotto pystyttiin mäărittämäăn kummassakin tuotantosuuntaryhmässă viimeiseltă tutkimusperiodilta. Pellon hyvyyden mittareina regressiomalleissa kăytettiin satotasodummeja (taulukko 16).

Pellon rajatuotosta văhennettiin tămän jălkeen sellaiset muuttuvat kustannukset, jotka eivăt sisältyneet nautakarja- tai viljatilojen tuotantofunktion selittäviin muuttujiin. Näin saatu rajakatetuotto osoitti sen markkamäăräisen korvauksen hehtaaria kohden, mikă nautakarja- ja viljatiloilla oli käytettävissä pellon hankintaan ennen veroja. Verojen osuuden määrittämiseksi maatalouden tulonlisäyksen aiheuttamaksi marginaaliveroasteeksi valittiin nautakarjatiloilla 40 ja viljatiloilla $50 \%$. Kertomalla lisäpellon rajakatetuotto kertoimella (1-rajaveroaste) saatiin molempien tuotantosuuntaryhmien pellon nettorajakatetuotto hehtaaria kohden selville (taulukko 18).

Lisäpellon tuottoarvoa laskettaessa käytettiin 3, 5 ja $7 \%$ :n korkokantaa, kun tuoton kestoajaksi valittiin 5 , 10 ja 15 vuotta. Naain määritetyt tuottoarvot nousivat tasaisesti nautakarjatiloilla ajan myötä. Viljatiloilla tuottoarvo jäi sitä vastoin hyvin alhaiseksi tutkimuskauden viimeistä periodia lukuunottamatta (taulukko 23).

Tutkittaessa pellon rajatuoton ja viljelmäkoon välistä riippuvuutta tilat jaettiin kummassakin tuotantosuuntaryhmässă kahteen suuruusluokkaan. Tulokset osoittivat pellon rajatuoton alle 25 hehtaarin nautakarjatiloilla olleen keskimäärin noin kolminkertainen suuremman viljelmäkokoryhmän tuloksiin verrattuna. Sitåvastoin viljatiloilla pellon rajatuotto kasvoi edelleen siirryttäessä alle 30 ha:n tilaryhmästă suurempaan. Myös keskimäăräisen verotettavan puhtaan tuoton käyttoooon perustuva erotustuottotarkastelu osoitti pellon rajatuoton tapaan peltoalan lisäämisestă saatavan hyödyn olevan suurin nautakarjatilojen pienimmissă tilasuuruusluokissa, kun taas viljatiloilla pellon rajatuotto ja erotustuotto pysyivăt korkeina viljelmäkoon kasvaessa.
Lisäpellosta maksetut kauppahinnat kerättiin maatilahallituksen maanhankintatilastosta vuosilta $1972-86$ ja maanmittaushallituksen tilastoimasta kiinteistöjen kauppahintarekisteristä. Jälkimmäisen tilaston tiedot oli saatavissa vain vuosien $1982-86$ osalta. Tuona viitenă vuotena kauppahintarekisterin mukaiset kaupat Etelä-Suomessa käsittivăt keskimäärin 1233 ha vuodessa, kun taas maatilahallituksen pellon ostoissa maata vaihdettiin vain 505 ha vuodessa. Vuotuiset pellon ostot olivat siten tutkimusalueen 1.1 milj. ha:n suuruisesta peltoalasta hieman yli promille.

Lisăpellon pinta-alalla painotettu keskihinta maanmittaushallituksen kaupoissa nousi voimakkaasti vuoteen 1985 saakka, mutta aleni viimeisenă tutkimusvuonna kuten seuraavasta elinkustannusindeksillä vuoden 1986 hintatasoon deflatoidusta aikasarjasta havaitaan:

$\begin{array}{ll}\text { vuosi } & \mathrm{mk} / \mathrm{ha} \\ 1982 & 25240 \\ 1983 & 27692 \\ 1984 & 31641 \\ 1985 & 33004 \\ 1986 & 31920 .\end{array}$

Keskimaaăräinen lisăpellon hehtaarihinta tutkimusalueella tarkasteltuina vuosina oli $29899 \mathrm{mk}$. Vuonna 1986 pellosta maksettiin korkeimmat hinnat Satakunnan ja Varsinais-Suomen maatalouskeskusten alueilla, joilla pellon hinta ylitti $43000 \mathrm{mk}$ hehtaarilta. Myös muina vuosina pellon hinta näillă alueilla oli selvästi korkein. Seuraavaksi kalleinta pelto oli vuosina 1982-86 Hămeen läänin maatalouskeskuksen alueella vaihtelurajojen ollessa $23000-35300 \mathrm{mk} / \mathrm{ha}$. Halvinta pelto oli sităvastoin Etelä-Karjalan, Pirkanmaan, Ită-Hämeen ja Kymenlaakson maatalouskeskusten alueilla. Näillä alueilla pellon reaalihinta kyseisină vuosina vaihteli $15 \quad 700-28300$ $\mathrm{mk} / \mathrm{ha}$.

Maatilahallituksen pellon ostoissa reaalihinnan nousu vuosina 1972-86 oli hyvin maltillinen. Trendin vuosimuutosten keskiarvo oli $1.7 \%$. Salaojitetun ja avo-ojitetun pellon määrällă oli merkittävă vaikutus maatilahallituksen ostaman pellon hintaan. Vuosina 1978-86 salaojitetusta pellosta maksettiin $37-60 \%$ avo-ojitettua peltoa enemmăn. Maatilahallituksen pellon ostoissa hintataso jäi selvästi maanmittaushallituksen hintoja alhaisemmaksi, sillă se oli keskimäărin vain noin $60 \%$ kauppahintarekisterin hinnoista.

Koska kirjanpitoviljelmien tulokset ovat noin viidenneksen alueen muita tiloja korkeammat, lisäpellon tuottoarvoihin tehtiin samansuuruinen tasoalennus. Tasoalennus huomioonottaen vertailu tuottoarvon ja kauppahintojen vălillă osoitti lisăpellon tuottoarvon nautakarjatiloilla yltăneen maatilahallituksen maksamiin pellon hintoihin kaikkina tarkasteltuina vuosina, kun tuoton kestoaikana käytettiin 15 vuotta ja laskentakorkokantana $3 \%$ :a (vrt. kuva 15). Kymmenen vuoden kestoajalla laskettu tuottoarvo ei enảă yltănyt maatilahallituksen hin- 
tatasoon kaikkina tarkasteltuina ajankohtina. Myös maanmittaushallituksen kauppahintojen taso ylitti vuosina $1982-86$ noin $10000 \mathrm{mk}$ :lla nautakarjatilojen korkeimman tuottoarvon.

Viljatilojen lisäpellon tuottoarvo jäi maatilahallituksen kauppahintojen alapuolelle kaikkina tarkasteltuina ajankohtina (vrt. kuva 16). Viljatilojen tuottoarvo oli selvästi korkein vuosina $1982-86$, jolloin se ylsi tasoalennus huomioonottaen lähes maatilahallituksen kauppahintojen tasoon 15 vuoden kestoaikaa ja $3 \%$ :n laskentakorkokantaa käyttăen. Kun viljatilojen korkein tuottoarvo tuolloin oli noin $16000 \mathrm{mk} / \mathrm{ha}$, ja maanmittaushallituksen kauppahinnat lăhes $30000 \mathrm{mk}$, kauppahinnat olivat siten lähes kaksi kertaa korkeammat. Viljatilojen lisäpellon tuottoarvo osoittautui myös selvästi nautakarjatiloja herkemmäksi satotason vaihtelulle.

Tuloksia arvioitaessa on syytä muistaa kirjanpitotilojen edustavan keskimääräistă suurempia viljelmiä, minkä lisäksi ne ovat rationaalisesti ja voimaperäisesti viljeltyjă tiloja. Tăstă syystă tulosten yleistämisessă on oltava varovainen. Samoin on asianlaita myös kauppahintojen suhteen. Siksi edellä esitetyt tutkimustulokset osoittavat lisäpellon keskimääräisen tuottoarvon ja kauppahintojen tason ja kehityksen Etelä-Suomessa vain suuntaaantavasti. Poikkeamat yksittäisillă viljelmillă voivat olla suuriakin. 